Természettudományok

1. Matematiko és számítástudományok

2. Fizikai tudományok

3. Kémiai tudományok

4. Földtudományok

5. Biológiai tudományok

1.6. Környezettudományok

1.7. Multidiszciplináris természettudományok

I niversity of

IS ebrecen

Müszaki tudományok

Debreceni Egyetem

2.2. Villamosmérnöki tudományok

2.3. Építészmérnöki tudományok

www.degyfk.hu/kulonlegesbanasmod

4. Anyagtudományok és technológiák

5. Gépészeti tudományok

2.6. Közlekedéstudományok

2.7. Vegyészmérnöki tudományok

2.8. Informatikai tudományok

2.9. Agrár müszaki tudományok

2.10. Katonai müszaki tudományok

2.11. Multidiszciplináris müszaki tudományok

3. Orvostudományok

3.1. Elméleti orvostud

3.2. Klinikai orvostud

3.3. Egészségtudom

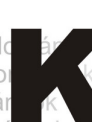

3.5. Multidiszciplináris or

.1. Növénytermesztèsi

2. Állatorvosi tudományo

3. Allattenyésztési tudomány

4.4. Élelmiszertudományok

4.5. Erdészeti és vadgazdá ko

4.6. Multidiszciplináris agrárt

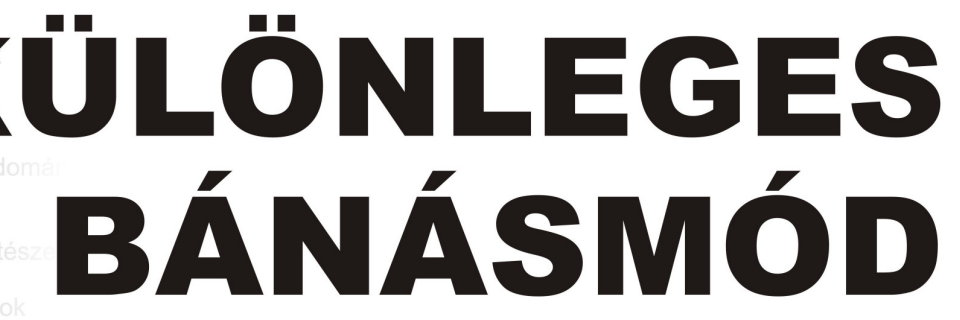

Interdiszciplináris szakmai lap

5. Társadalomtudományok

5.1. Gazdalkodas- es szerve zze

5.2. Közgazdaságtudományo
5.3. Állam- és jogtudományol

5.4. Szociológiai tudomán ye

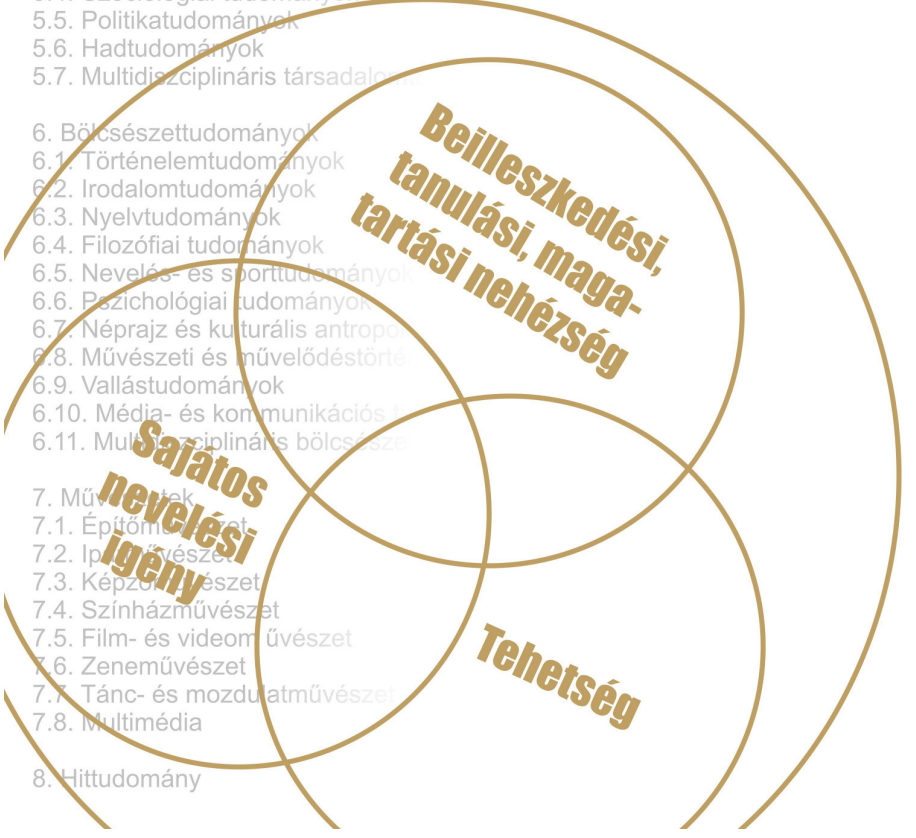

I. évfolyam 2015/2.

DOI 10.18458/KB.2015.2.1 


\section{IMPRESSZUM}

\section{KÜLÖNLEGES BÁNÁSMÓD - INTERDISZCIPLINÁRIS SZAKMAI LAP}

Alapítva: 2014-ben.

A Nemzeti Média- és Hírközlési Hatóság Hivatala a médiaszolgáltatásokról és a tömegkommunikációról szóló 2010. évi CLXXXV. törvény 46.§ (4) bekezdése alapján nyilvántartásba vett sajtótermék (határozatról szóló értesítés iktatószáma: $\mathrm{CE} / 32515-4 / 2014)$.

Kiadó: Debreceni Egyetem

A kiadó székhelye:

Debreceni Egyetem

4032 Debrecen, Egyetem tér 1.

Kiadásért felelős személy: Szilvássy Zoltán József, rektor

\author{
A szerkesztőség levelezési címe: \\ Debreceni Egyetem \\ Gyermeknevelési és Felnőttképzési Kar \\ Különleges Bánásmód folyóirat szerkesztősége \\ 4220 Hajdúböszörmény, Désány István u. 1-9. \\ Tel/fax: 06-52/229-559 \\ E-mail: titkarsag@ped.unideb.hu \\ Web: www.degyfk.hu \\ Szerkesztésért felelős személy: \\ Mező Ferenc
}

Alapító főszerkesztő: Mező Ferenc (Debreceni Egyetem, Magyarország)

Tanácsadó testület (ABC rendben):

Balogh László (Magyar Tehetséggondozó Társaság, Magyarország)

Gerevich József (Eötvös Lóránd Tudományegyetem, Magyarország)

Hatos Gyula ( Magyarország)

Koncz István (Professzorok az Európai Magyarországért Egyesület, Magyarország)

Mesterházy Zsuzsanna (Eötvös Lóránd Tudományegyetem, Magyarország)

Nagy Dénes (Melbourne University, Ausztrália)

Varga Imre (Szegedi Tudományegyetem, Magyarország)

Szerkesztőség (ABC rendben):

Bernáth Krisztina (Partiumi Keresztény Egyetem, Románia)

Dávid Mária (Eszterházy Károly Főiskola, Magyarország)

Egri Tímea (Eötvös Lóránd Tudományegyetem, Magyarország)

Fónai Mihály (Debreceni Egyetem, Magyarország)

Horváth László (Debreceni Egyetem, Magyarország)

János Réka (Babes-Bolyai Tudományegyetem, Románia)

Lepeš, Josip (University of Novi Sad, Szerbia)

Kelemen Lajos (Poliforma Kft., Magyarország)

Kiss Szidónia (Babes-Bolyai Tudományegyetem, Románia)

Kondé Zoltánné Dr. Inántsy-Pap Judit (Debreceni Egyetem, Magyarország)

Kormos Dénes (Miskolci Egyetem, Magyarország)

Láda Tünde (Debreceni Egyetem, Magyarország)

Márton Sándor (Debreceni Egyetem, Magyarország)

Mező Katalin (Debreceni Egyetem, Magyarország)

Molnár Balázs (Debreceni Egyetem, Magyarország)

Nagy Lehocky Zsuzsa (Konstantin Filozófus Egyetem Nyitra, Szlovákia)

Nemes Magdolna (Debreceni Egyetem, Magyarország)

Sarka Ferenc (Miskolci Egyetem, Magyarország)

Schéder Veronika (Debreceni Egyetem, Magyarország)

Szabó Edina (Debreceni Egyetem, Magyarország)

Szilágyi Barna (Debreceni Egyetem, Magyarország)

Váradi Natália (II. Rákóczi Ferenc Kárpátaljai magyar Főiskola, Ukrajna)

Vargáné Nagy Anikó (Debreceni Egyetem, Magyarország)

Note: The title of the journal comes from a Hungarian Act CXC of 2011. on National Public Education in which they use the term 'Különleges Bánásmód', and this translates as Special Treatment, but this encompasses the areas of Special Educational Needs, Talented Children and Children with Behaviour and Learning Difficulties. The adoption of Special Treatment is therefore in accordance with Hungarian law, but it is recognised that the translation may not be perfect in expressing the full meaning of what is encapsulated in this term. 


\section{TARTALOM}

\section{EMPIRIKUS TANULMÁNYOK}

Bolgár Brigitta és Ráduly-Zörgő Éva:

Hallássérült tanulók logikai-matematikai

képességeinek fejlesztése táblajátékokkal

Schranz Edit:

Tehetségböl - kiváló

Kutatás közben: a külföldön munkát vállaló, fiatal diplomás nök életkezdési esélyei

MÓDSZERTANI TANULMÁNYOK

Abari Kálmán, Mező Ferenc, Mező Katalin és Máth János:

A fejlesztöprogramok hatásvizsgálatát szolgáló adatbázisok

szerkezete egy ingyenes statisztikai szoftverben: az R-ben.....

Nagy Lehocky Zsuzsa és Patai Ilona:

Hiperaktív gyermek az osztályban .....

Bojti István és Schéder Veronika:

Narratív szemlélet a segítö kapcsolatban.

Szabó Edina:

A dinamikus szenzoros integrációs terápia (dszit) a verbális kommunikációs zavarok rehabilitációjában

Orbán Réka:

Tanulásban akadályozott gyermekek kognitív fejlesztésének lehetőségei

Bagány Ágnes, Major Lenke és Josip Lepeš:

A szociális kompetencia fejlödése a hátrányos helyzetü gyerekeknél

KÖNYVAJÁNLÁS, RECENZIÓ

Mezö Ferenc:

Koncz István nagy kézikönyve trénereknek.....

KONFERENCIA...

Meghívó a koragyermekkori nevelés címü nemzetközi tudományos konferenciára 


\section{EMPIRIKUS ÉS ÉRTEKEZŐ TANULMÁNYOK}




\title{
HALLÁSSÉRÜLT TANULÓK LOGIKAI-MATEMATIKAI KÉPESSÉGEINEK FEJLESZTÉSE TÁBLAJÁTÉKOKKAL
}

\author{
Szerzők: \\ Bolgár Brigitta, \\ Komutza Flóra Hallássérültek Iskolája \\ (Románia) \\ Ráduly-Zörgő Éva \\ Babes-Bolyai Tudományegyetem
}

(Románia)

\author{
Lektorok: \\ Kiss Szidónia \\ Babes-Bolyai Tudományegyetem \\ (Románia) \\ Péntek Imre \\ Babes-Bolyai Tudományegyetem \\ (Románia) \\ Mező Ferenc \\ Debreceni Egyetem \\ Szabó Edina \\ Debreceni Egyetem
}

Első szerző e-mail címe:

bolgarbrigi@yahoo.com

Bolgár Brigitta és Ráduly-Zörgő Éva (2015): Hallássérült tanulók logikai-matematikai képességeinek fejlesztése táblajátékokkal. Különleges Bánásmód, I. évf. 2015/2. szám, 5-16. DOI 10.18458/KB.2015.2.5

\begin{abstract}
Absztrakt
A matematika tanulása sikeres lehet, és sok örömet okozhat a hallássérült gyermekeknek. Kutatásunkban a matematikai teljesítményt megalapozó bázisképességek, a problémamegoldás és a logikai gondolkodás táblajátékokkal történö fejlesztésének hatékonyságát vizsgáljuk hallássérült diákoknál. Minta: $n=10$ (2 lány, 10 fiú) hallássérült diák (átlagéletkor: 11,6 év). Módszer: logikai-matematikai képességek felmérése fejlesztés elött és után. Eredmény: a stratégiai játékok, táblás játékok használata a problémamegoldó képesség fejlödése mellett szignifikánsan befolyásolja a matematikai képességek fejlödését, a matematikai tantárgyi ismeretek elsajátítását is.
\end{abstract}

Kulcsszavak: logikai-matematikai képességek, hatékony tanulási környezet, játékos képességfejlesztés, táblajátékok

Diszciplínák: gyógypedagógia, pedagógia, matematika

\begin{abstract}
DEVELOPMENT OF LOGICAL-MATHEMATICAL ABILITIES OF HEARING IMPAIRED STUDENTS THROUGH THE USE OF BOARD GAMES

Students with hearing impairment can be successful at and enjoy studying mathematics. Our research focuses on studying the effectiveness of using board-games in developing basic mathematical skills and logical thinking in students with hearing impairment. Sample: $n=10$ (2 females, 10 males) hearing impaired pupils (average age $=11,6$ years). Method:
\end{abstract}


examination of logical-mathematical abilities before and after development. Result: strategic and logic-based games significantly impacted on the development of mathematical skills and knowledge acquisition in mathematics.

Keywords: logical and math skills, effective learning environment, game-based skill development, board games

Disciplines: special education, pedagogy, mathematics

Nyilvánvaló, hogy a jelenlegi gyorsan változó gazdasági, társadalmi feltételek között szükséges a közoktatásban a matematika tanításának „merészebb” átalakítása egy realisztikusabb matematikaoktatás felé, ami a matematika hasznosságának és hasznosíthatóságának kiemelését jelenti mind tartalomban, feladatokban, problémákban, mind módszertani vonatkozásban.

Mintegy másfél évtizede követhetőek nyomon a konstruktív tanulási koncepcióval és a hatékony tanulási környezetekkel kapcsolatos publikációk. A konstruktív tanulási koncepció szerint a hatékony matematikatanulás önszabályozó, szituációs és együttműködő, ahol a tanulót a környezettel való együtthatás során figyelmesen és erőfeszítést igénylően vonjuk be a tudás- és készségelsajátítási folyamatba (Vidákovics és tsai, 2008).

Wilson (1995) szerint a hatékony, konstruktív fejlesztési környezet olyan hely, ahol a tanulók együtt dolgozhatnak és segíthetik egymást, változatos eszközöket és információs forrásokat használnak fel a tanulási célok elérésére és a problémamegoldó tevékenységekhez.

A matematika oktatásának hatékonysága attól függ, hogy mennyire tudjuk segíteni tanulóinkat abban, hogy keressék és megtalálják az alapvető rendszereket, ebbe bele tudják illeszteni az új ismereteket, akkomodálni tudják elsajátított sémáikat, azaz legyenek képesek átalakítani rendszereiket az új befogadása érdekében.

Ebben a folyamatban meghatározó a cselekvéses tapasztalatgyüjtés. A manipulatív tevékenység (ami lehet tárgyakkal, eszközökkel végzett konkrét tárgyi tevékenység, és lehet matematikai példákkal, képzetekkel, tapasztalatokkal, eljárásokkal folytatott „tárgyi” tevékenység) döntő láncszem a matematikai ismeretszerzésben. Ez után következik a tapasztalatokra alapuló lényegi fogalmak gyüjtése, a lényegtelen elemek kiszürése, egyszerü fogalmak kialakítása, majd ezen fogalmak magasabb szintü fogalmi rendszerekbe való beépítése, müveletvégzés az elsajátított fogalmakkal, algoritmusok kialakítása, valamint a matematika különböző fogalomrendszerei közötti kapcsolatok feltárása és problémahelyzetekben való alkalmazása.

Skemp (2005) szerint definíció segítségével senkinek nem közvetíthetünk az általa ismerteknél magasabb rendü fogalmakat, hanem csakis oly módon, hogy a megfelelö példák sokaságát nyújtjuk, olyan példákat, amelyek megfelelnek a diák gondolkodás fejlettségi szintjének. Saját fogalomrendszert mindenkinek egyedül kell kiépítenie. A folyamat azonban felgyorsítható, ha a hozzá szükséges anyagok kéznél vannak. Ezek a „szükséges anyagok” a megfelelő munkaformák, módszerek, eszközök, tanári tevékenység, motiváció stb. széles tárházát jelentik.

Az utóbbi években elötérbe került a kompetencia alapú oktatás, amely lehetővé teszi, hogy a külön szerzett és fejlesztett képességek, jártasságok, készségek szerves egységbe szerveződjenek, és együtt fejtsék ki hatásukat a problémák megoldásában, a gondolkodásban és az ismeretek gyakorlati alkalmazásában. 
Nagy J. (1998) funkcionális személyiségmodellje alapján a matematikai kompetencia a kognitív kompetencia részrendszereként értelmezhető, melyben a terület specifikus komponensek mellett általános, más területeken is müködő összetevők is vannak.

A matematikai készségek és képességek rendszere több irányból feltérképezhető. Kiindulási alap lehet például az intelligencia, mely a kognitív kompetencia nagy részét magába foglalja, így az intelligencia alkotóelemeivel, szerkezetével kapcsolatos kutatások (faktoranalízisek) eredményei alapján sokféle matematikai készség és képesség azonosítható.

Elemezhetjük ugyanakkor közvetlenül a matematikatanítás célrendszereit, tanterveit, illetve a matematikatanítást segítő egyéb anyagokat (módszertani segédanyagokat) is, melyek szintén számos, a matematikatanítás számára fontos, fejlesztendő és értékelendő készséget és képességet említenek. Az 1. táblázat a matematikai kompetencia készség- és képességkomponenseit összegzi.

1. táblázat: A matematikai kompetencia készség-és képességkomponensei a faktoranalizis és a tartalmi elemzések alapján (Vidákovics és tsai, 2008, 18. o.),

\begin{tabular}{|c|c|c|c|c|}
\hline Készségek & $\begin{array}{l}\text { Gondolkodási } \\
\text { képességek }\end{array}$ & $\begin{array}{l}\text { Kommunikációs } \\
\text { képességek }\end{array}$ & $\begin{array}{l}\text { Tudásszerző } \\
\text { képességek }\end{array}$ & $\begin{array}{l}\text { Tanulási } \\
\text { Képességek }\end{array}$ \\
\hline $\begin{array}{l}\text { számlálás, } \\
\text { számolás, } \\
\text { mennyiségi } \\
\text { következtetés, } \\
\text { becslés, mérés } \\
\text { mértékegység- } \\
\text { váltás, } \\
\text { szövegesfeladat- } \\
\text { megoldás }\end{array}$ & $\begin{array}{l}\text { rendszerezés, } \\
\text { kombinativitás, } \\
\text { deduktív } \\
\text { következtetés, } \\
\text { induktív } \\
\text { következtetés, } \\
\text { valószinüségi } \\
\text { következtetés, } \\
\text { érvelés, bizonyítás }\end{array}$ & $\begin{array}{l}\text { relációszókincs, } \\
\text { szövegértés, } \\
\text { szövegértelmezés, } \\
\text { térlátás, térbeli } \\
\text { viszonyok, } \\
\text { ábrázolás, } \\
\text { prezentáció }\end{array}$ & $\begin{array}{l}\text { probléma- } \\
\text { érzékenység, } \\
\text { probléma-- } \\
\text { reprezentáció, } \\
\text { eredetiség, } \\
\text { kreativitás, } \\
\text { problémamegoldás } \\
\text { metakogníció }\end{array}$ & $\begin{array}{l}\text { figyelem, } \\
\text { rész-egész észlelés, } \\
\text { emlékezet, } \\
\text { feladattartás, } \\
\text { feladat-megoldási } \\
\text { sebesség }\end{array}$ \\
\hline
\end{tabular}

A táblázatban felsorolt készségek és képességek egy része (a dölt betüvel kiemeltek) a matematikatanulás, a matematikai kompetencia szempontjából meghatározó jelentőségü, ún. kritikus faktornak tekinthető, melyek megfelelő fejlesztését már elemi osztályokban biztosítani kell. Ezek az összetevők struktúrájukban, bonyolultságukban nagyon különböznek egymástól.

A gondolkodási képességek között több olyan is van, amely ugyan nem kifejezetten területspecifikus, de a matematikai tudásra nézve mégis jellemző lehet. Ezek a képességek ugyanis jól mutatják az egyén általános értelmességét, és mint ilyenek, általában jól korrelálnak a matematikai eredményességgel is. Az általános gondolkodási képességek, a rendszerezés, a kombinativitás, a deduktív, az induktív, valamint a mennyiségi következtetés jól mérhetőek, akár már a kisgyermekkorban is.

A mennyiségi következtetés már egyértelmüen alapvető matematikai gondolkodási képesség, azaz egyike a matematika-specifikus összetevőknek. Kapcsolódó intelligencia-komponensek a számlálás, a számolás, a számolásos következtetés (például az arányosságok kezelése). Ezek mind a matematikai kompetencia kulcselemei, alkalmazásuk az egyszerü szöveges feladatok megoldásában teljesedik ki.

A nyelvi kommunikáció és a vizuális kommunikáció komponensei általában nem matematika-specifikusak. Olyan készségek, képességek tartoznak ide, amelyek a tanulás során sokféle tantárgyban fejleszthetőek. A relációszókincs, a szövegértés, a szövegértelmezés 
azonban a matematikai feladatmegoldás során is fontos, különösen, ha a matematikai szöveges feladatok megértésére, illetve az erre épülö problémareprezentációra gondolunk. A nyelvi fejlettség akkor is lényeges lehet, ha a matematikai feladat szimbolikus formában közölt, mivel a megfelelő nyelvi fejlettségi szint a szimbólumok azonosításához, megkülönböztetéséhez is szükséges.

A vizuális kommunikáció képességcsoportjában a térlátás és a térbeli viszonyok az alapvető komponensek. A pszichometriai tanulmányok a téri képességeken belül különböző képességfaktorokat azonosítottak. Ilyenek: a téri percepció (téri kapcsolatok felfogása, meghatározása, téri lokalizáció), téri vizualizáció (téri műveletek), mentális forgatás (két- vagy háromdimenziós alakzatok mentális forgatása) (Stiles és mtsai., 2013).

Kozhenvikov, Hegarty és Mayer (2002) szerint azok a személyek, akik számára nem jelent nehézséget a tárgy elemei közötti relációk megállapítása, a tárgyak térben való mentális mozgatása, a mentális forgatás, sokkal sikeresebbek a matematikai problémamegoldásban, mint a képi ábrázolásban jeleskedők.

A tudásszerzö képességcsoport fontossága is kétségtelen, hiszen ezek a képességek adnak lehetőséget a matematikai kompetencia alkotó alkalmazására. A problémaérzékenység, az eredetiség és a kreativitás azonban nemcsak a matematika számára fontosak, értékük és szükségességük más tantárgyakban és a mindennapokban is nyilvánvaló, fejlesztésükre mégis csupán kevés pedagógus vállalkozik. A matematikai kompetencia hagyományosan fontosnak tekintett komponensei a feladat- és problémamegoldás készségei, képességei. A feladatmegoldás alapkészségei erősen matematika-specifikusak. A problémamegoldásra való képességhez egy sor egyéb pszichés tulajdonság megléte szükséges: kreativitás, összefüggések meglátása, ítélőképesség, bizonyításra való képesség, transzfer (azaz az ismeretek más területen való alkalmazása), kombinatorikus gondolkodásra való alkalmasság stb.

A tanulási képességek csoportjában a figyelem, a memória terjedelme, az asszociatív memória meghatározó komponensek. A fejlesztés bármelyik tantárgy keretein belül megvalósulhat, de önálló gyakorlással is megoldható. Alkalmas formát jelenthet még a tanóráktól független, játékos feladatmegoldás, verseny (Vidákovich T. és tsai, 2008).

Ami a hallássérültek matematikai képességeit illeti, speciális iskolákban tanuló diákoknál azt találták, hogy bár matematikai eredményeik jobbak, mint az írás-olvasás terén elért eredmények, halló társaikhoz viszonyítva mégis nagy az elmaradás

1957-ben Angliában, a Hallássérülteket Tanító Pedagógusok Szövetsége által végzett országos felmérésben azt találták, hogy a hallássérült tanulók 2,5 éves lemaradást mutatnak matematikai teljesítmény terén. Két évtized után Wood, Wood és Howarth (1983) hallássérült tanulók matematikai gondolkodását vizsgáló kutatásának eredményei szerint a halló gyermekek tudása e téren 3,4 évvel meghaladja a hallássérültekét, attól függetlenül, hogy azok milyen iskolatípusba, speciális iskolákba,vagy integrált osztályokba jártak. A vizsgált gyermekek hallásvesztesége 30-120 dB-ig terjedt, de a hallássérülés foka nagyon kis különbséggel mutatkozott meg a gyermekek eredményeiben. Ugyanígy, kevéssé volt meghatározó az iskolatípus, ahova a gyerekek jártak. Úgy tünik, inkább az oktatási környezeten belül meglevő tényezők hatnak a gyermekek ilyen irányú teljesítményére.

A fent említett vizsgálati populáció 15\%-a (súlyosan hallássérült diákok) átlagos vagy átlag feletti eredményeket ért el a matematikai felméréseken. Nem általánosítható tehát az a kijelentés, ami szerint a hallássérülés kötelező módon alacsonyabb matematikai teljesítményszintet von maga után. Ugyanakkor vizsgálati eredmények alapján megállapítható, hogy ami a számolást, matematikai alapmüveleteket és problémamegoldó képességek fejlődését illeti, hallássérülteknél is ugyanaz a fejlődési folyamat, csak mindez lassúbb ritmusban zajlik (Nunes és Moreno, 2002). 
Marschark (2003) szerint a jelenlegi oktatási rendszerben a problémát nem maguk a hallássérült diákok képezik, hanem a velük szemben támasztott helytelen elvárások, képességeiknek és igényeiknek nem megfelelő oktatási módszerek.

A hallássérülteket oktató pedagógusok számára komoly kihívást jelent a nyelvi hiányosságok kiküszöbölése (jelnyelvi kommunikáció is), a súlyosan hallássérült és siket tanulók vizuális igényeinek megfelelő nevelési környezet kialakítása, olyan módszerek, eszközök használatával, amelyek a logikai gondolkodás, számfogalom és hatékony probléma megoldási stratégiák kialakulásához megfelelő alapot és tapasztalatot biztosítanak.

A különféle játékok felhasználása az iskolai - és bármiféle - oktatás során egyáltalán nem új jelenség; már az ókorban felismerték, hogy a játéktevékenység közbeiktatása hatékonyabbá teheti a tanítást és a tanulást.

Szentiványi (2000) szerint a kreatív problémamegoldásnak nagyon hasznos eszközei a logikai játékok, hiszen az absztrakt stratégiai játéknál mindenki számára természetes, hogy egy-egy lépés megtétele előtt egy sor alternatívát gondolunk végig és megpróbáljuk kiválasztani a legkedvezőbb lépést.

A táblajáték olyan, általában bábuval vagy koronggal játszott játék, amelyet egy elöre elkészített mezőn, meghatározott szabály szerint egy vagy több személy játszhat. Egy megfelelően alkalmazott stratégia lehet a játék lényege, de szerencsén is múlhat a siker, vagy akár mindkettőn, ahol a cél a győzelem (K. Nagy Emese, 2014).

Nagy (2000) szerint a táblajáték az ember talán legjellemzőbb találmánya, magasabb intelligenciájának egyik kétségbevonhatatlan ,bizonyítéka”, hisz az absztrakciót feltételező táblajátékra csak a gondolkodó ember képes.

Táblajátékok során a gyerek ,fejben tervez, stratégiát épít fel, algoritmust állít fel, taktikát dolgoz ki. Lehetőségeket vesz sorra, analizál, szintetizál, analógiákat használ, osztályoz, rendez, összehasonlít, számlál, számol, becslést végez, síkban, térben tájékozódik. Elválasztja a lényegest a lényegtelentől, az újszerüt a szokványostól, konstruál, vagyis alkot. Kockázatot vállal, sorozatos döntéseket hoz, képzeletét, emlékezetét csiszolja. Folytonosan önuralmat gyakorol, hiszen folyamatosan siker- és kudarcélménnyel szembesül. Gyakorolja az együttlét elemi normáit. A játék során ismeretségeket, barátságokat köt, elfogad másokat, beszélget, vagyis kommunikál. Mindezt élményszerüen megélve” (K. Nagy E., 2012, 65.).

Számtalan publikáció jelent meg (néhány már magyar nyelven is) a logikai- és táblajátékok innovatív felhasználására vonatkozóan is. Ezek az írások beszámolnak azokról a kutatásokról, amelyek szerte a nagyvilágban folynak ezen a téren, az oktatásban. Rendkívül pozitívak a tapasztalatok, jelentősen javul a tanulók teljesítménye, különösen az olvasás-szövegértés és a matematika terén.

Duró (2007) a sakk képességfejlesztő hatását vizsgálta nagycsoportos és 1.-2. osztályos magyarországi kisiskolásoknál. Eredményei azt bizonyították, hogy a sakk oktatása és rendszeres gyakorlása kedvező befolyást gyakorol a kisgyermekek bizonyos részképességeire.

Grabner, Stern és Neubauer (2006 - idézi Csíkos, 2007) azt találták kutatásukban, hogy a sakkban elért játékerő szoros összefüggést mutat az intelligenciateszten elért eredménnyel, különösen a számolással kapcsolatos intelligenciafaktorban.

A világ számos országában - Indonéziától Brazíliáig, vagy Nagy-Britanniától Dél-Afrikáig -müködik a Yale Egyetemen tesztelt MINDLAB program, amely a logikai és táblás játékok széles és színes skáláját alkalmazza a gyerekek fejlesztésére. A Mindlab koncepciója azon az elképzelésen alapul, hogy a stratégiai játékok hatásos oktatási eszközként is szolgálhatnak. A társasjátékok hozzájárulnak a kognitív képességek fejlődéséhez, illetve a gondolkodási folyamat tudatosításához. Számos oktatási kutatás alátámasztja a Mindlab hatékonyságát a problémamegoldó képesség, a matematikai és nyelvi készségek fejlődése terén (Garcia és Abed, 2010). 


\section{A kutatás módszertani vonatkozásai}

A vizsgálatban a kolozsvári Kozmutza Flóra Hallássérültek Speciális Iskolájának 4.-5. osztályos hallássérült diákjai vettek részt, összesen 10 diák: 2 lány és 8 fiú. A résztvevők átlagéletkora: 11,6 év.

$\mathrm{Az}$ 1. ábra a vizsgálati minta megoszlását ábrázolja a hallássérülés mértéke és IQ szerint. $\mathrm{Az}$ adatokat az iskola audiológusa és pszichológusa szolgáltatta. Az intellektuális képességek felmérése a Raven teszttel történt (SPM-Parallel verzió).

1. ábra: A vizsgálati minta megoszlása a hallássérülés mértéke és IQ szerint (forrás: a Szerzők)

Hallássérülés mértéke szerinti megoszlás

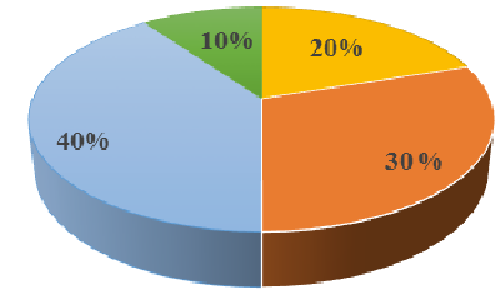

口közepes n.h - súlyos n.h $\square$ siket $\square$ nem h.s
IQ szerinti megoszlás

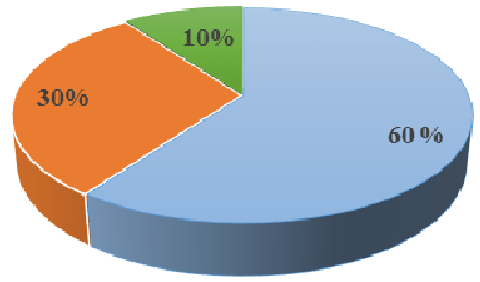

■átlagos - átlag feletti घigen magas

\section{A vizsgálat célja}

- A vizsgálatban résztvevő 4-5. osztályos hallássérült diákok matematikai bázisképességeinek felmérése.

- A matematikai teljesítményt megalapozó képességek, jelentősebb részképességek (gondolkodási, téri-vizuális, tudásszerző képességek) feltérképezése, felmérése.

- A diákok egyéni, életkori és sérülés-specifikus sajátosságaihoz, képességeihez igazodó táblajátékos fejlesztő program kidolgozása és alkalmazása.

- A táblajátékos fejlesztő program hatékonyságának felmérése, kiértékelése; a program indításakor és lezárásakor készült vizsgálati képességprofilok összehasonlítása annak érdekében, hogy a diákok önmagukhoz viszonyított fejlődési szintjét megállapíthassuk.

\section{Hipotézisek}

1. Egy intenzív, táblajátékokra támaszkodó fejlesztő program jelentősen javítja a 4.-5. osztályos hallássérült tanulók téri-vizuális képességeit, gondolkodási képességeit, vizuális emlékezetét és figyelmét.

2. Az intenzív, táblajátékokra épült fejlesztő program hatékonyan befolyásolja a hallássérült diákok alapvető matematikai képességeinek (numerikus bázisképességek) alakulását és a matematikai tantárgyi eredményességet.

\section{A vizsgálat terve}

A vizsgálat a 2014-2015-ös tanév II. félévében, a kitüzött célokat szem előtt tartva a következö lépésekben zajlott: 
- matematikai képességek, a matematikai teljesítményt megalapozó képességek felmérése

- táblajátékos fejlesztő program alkalmazása (osztályszinten - csoportos tevékenység)

- a fejlesztő program hatékonyságának felmérése, kiértékelése

\section{Az elö és utómérésekben alkalmazott módszerek és eszközök}

A vizsgálat két fö területre irányult:

- alapvető matematikai képességek (numerikus bázisképességek) felmérése

- matematikai teljesítményt megalapozó képességek felmérése

\section{Alapvetö matematikai képességek felmérése}

A matematikai képességek felmérése során elsősorban nem a tantárgyi ismeretek felmérése volt a cél, hanem az alapvető számolási képességek (numerikus bázisképességeket) fejlettségi szintjének a megállapítása.

A felmérésre használt feladatsor összeállításánál szem előtt tartottuk azokat a szempontokat, amelyeket Juhász és Dékány (2007) javasol az 1.-4. osztályos diákok tipikus számolási hibáinak azonosítására, valamint a McCloskey (1992), Delazer és mtsai (2003) (idézi Karicsi, 2010) által kidolgozott neuropszihologiai számolásmodellek elméleti alapjaira épített Numerikus Feldolgozás és Számolás Teszt feladatcsoportjait és feladattípusait.

A felmérés a következő területekre terjed ki: számfogalmak megfigyelése és felmérése, globális mennyiségfelismerés, számemlékezet, mennyiségállandóság, helyiérték, alapmüveletek és inverzei (pótlás, bontás), müveletvégzés (összeadás, kivonás egységrend átlépéssel), egyszerü szöveges feladat értelmezése, megoldása, logikai számsorok felismerése és folytatása.

\section{Matematikai teljesítményt megalapozó képességek felmérése}

Ebben a tekintetben a Vidákovics és tsai (2008) által összegzett, matematikai kompetencia komponenseiként meghatározott képességek közül válogattuk ki azokat, amelyekre feltételezéseink szerint a táblajátékos program fejlesztő hatást gyakorol.

A következő képességek felmérésére került sor:

- téri-vizuális képességek: téri irányok, téri viszonyok, mentális forgatás

- gondolkodási képességek: figurális absztrakciós képességek, analízis, kombináció, összehasonlítás, ítélőképesség, döntéshozás

- vizuális emlékezet: képekre és mértani formákra való emlékezés

- figyelem: disztributív figyelem

A fent említett képességek vizsgálatára a pedagógiai gyakorlatban használt felmérési eszközök közül azok mellett döntöttünk, amelyek kevésbe alapoznak verbális utasításokra és megfelelnek a vizsgált populáció életkori, sérülés-specifikus sajátosságainak.

A cél a diákok képességprofiljának minél részletesebb feltérképezése volt, az önmagukhoz és csoportjukhoz viszonyított fejlödési szint megállapítása, nem a standardizált teszteredményekhez, etalonokhoz való viszonyítás. A felmérési eredmények alapján állítottuk össze a táblajátékos fejlesztőprogramot és határoztuk meg a kiválasztott játékok, gyakorlatok nehézségi fokát úgy, hogy lehetőség legyen a differenciálásra, a megfelelő szintü egyéni fejlesztésre.

A kutatás során használt játékok: tic-tac-toe (X-O), tőtikék, amőba (gomoku), Quarto, paraszt, dáma, ősmalom, tradicionális halma, csillag halma, mancala, british sguare, pentonimók, Blokus.

A tevékenységek osztályszinten zajlottak, három hónapon keresztuil heti két alkalommal. 
A tevékenységek célja:

1. játékcsaládok, játéktípusok ismertetése: jártasság megszerzése több játékcsaládban, feladványokban, rejtvények megfejtésében, a közös jellemzők vagy eltérések megtalálása és elemzése egy-egy játékcsaládon belül, nyerő stratégiák, algoritmusok keresése, problémák többoldalú megközelítése, gyakorlatorientáltság kialakítása (próbálgatás, megoldáskeresés).

2. általános képességfejlesztés - kognitív képességek fejlesztése: lényeglátás-lényegkiemelés, rendszerszemlélet, összpontosítás, tartós figyelem, logikus gondolkodás, intuíció, kreativitás, emlékezet, térszemlélet, téri orientáció, képzelet, absztrakció, analitikus gondolkodás.

3. matematikai képességek fejlesztése: számolás, pótlás-bontás, globális mennyiségfelismerés, becslés, müveletvégzés.

\section{A vizsgálat eredményeinek mennyiségi és minőségi elemzése}

A táblajátékos fejlesztőprogram hatékonyságának felmérése céljából a fejlesztőprogram befejezése után újra felmértük és értékeltük a vizsgálatban részt vevő diákok alapvető matematikai képességeit, valamint a matematikai teljesítményt megalapozó képességeket.

Annak megállapítására, hogy a felmért képességek terén bekövetkezett fejlődés mennyire szignifikáns, egymintás t-próbával (páros t-teszt) hasonlítottuk össze a pre- és poszttesztben elért eredményeket. A 2. táblázat a matematikai teljesítményt megalapozó képességeket mérö feladatokban elért csoportos pre- és posztteszt átlagteljesítmény különbségének szignifikancia szintjét tartalmazza. Amint az látható, a fejlesztőprogram hatására jelentősen javult a csoport átlagteljesítménye a matematikai teljesítményt megalapozó képességeket mérő feladatokban.

2. táblázat: Matematikai teljesítményt megalapozó képességek terén elért csoportos átlagteljesítmény összehasonlító táblázata (forrás: a Szerzők)

\begin{tabular}{|l|c|c|c|c|c|}
\hline \multicolumn{1}{|c|}{ Teszt } & n & M & SD & t & p \\
\hline Preteszt & 10 & $57.80 \%$ & 13.45 & \multirow{2}{*}{8.3721} & \multirow{2}{*}{0.0001} \\
\hline Posztteszt & 10 & $74.50 \%$ & 13.74 & & \\
\hline
\end{tabular}

A 2. ábra a felmért matematikai teljesítményt megalapozó képességek területén, pre- és poszttesztben elért, képességekre lebontott átlagos csoportteljesítményt összegzi. Amint a 2. ábrán látható, minden képesség terén fejlődés tapasztalható. Legjelentősebb a fejlődés a térivizuális képesség (20,7\%-os fejlődés), a figyelem (17\%-os fejlődés) és a Kohs-próba terén (28\%-os fejlödés).

A matematikai teljesítményt megalapozó különböző képességek területén bekövetkezett fejlődés szignifikanciájának adatait a 3. táblázat összegzi.

A $t$ és $p$ értékek bizonyítják, hogy a táblajátékos fejlesztőprogram hatására szignifikáns fejlődés tapasztalható a vizsgált matematikai teljesítményt megalapozó képességek terén. A fent összegzett eredmények alapján megállapítható, hogy a táblajátékos fejlesztőprogram hatására:

- jelentős fejlődés mutatható ki a téri-vizuális képességek és a vizuális disztributiv figyelem terén,

- fejlődés tapasztalható a vizuális emlékezet terén is, főleg mértani formákra való emlékezés vonatkozásában,

- a legjelentősebb fejlődés a gondolkodási képességek terén, az analízist, kombinációt, összehasonlítást, ítélöképességet, döntéshozást igénylő Kohs-próbában nyújtott teljesítmény terén mutatható ki. 
2. ábra: A matematikai teljesítményt megalapozó képességek terén elért átlagos csoportteljesítmény pre-és posztteszt eredményei (forrás: a Szerzők)

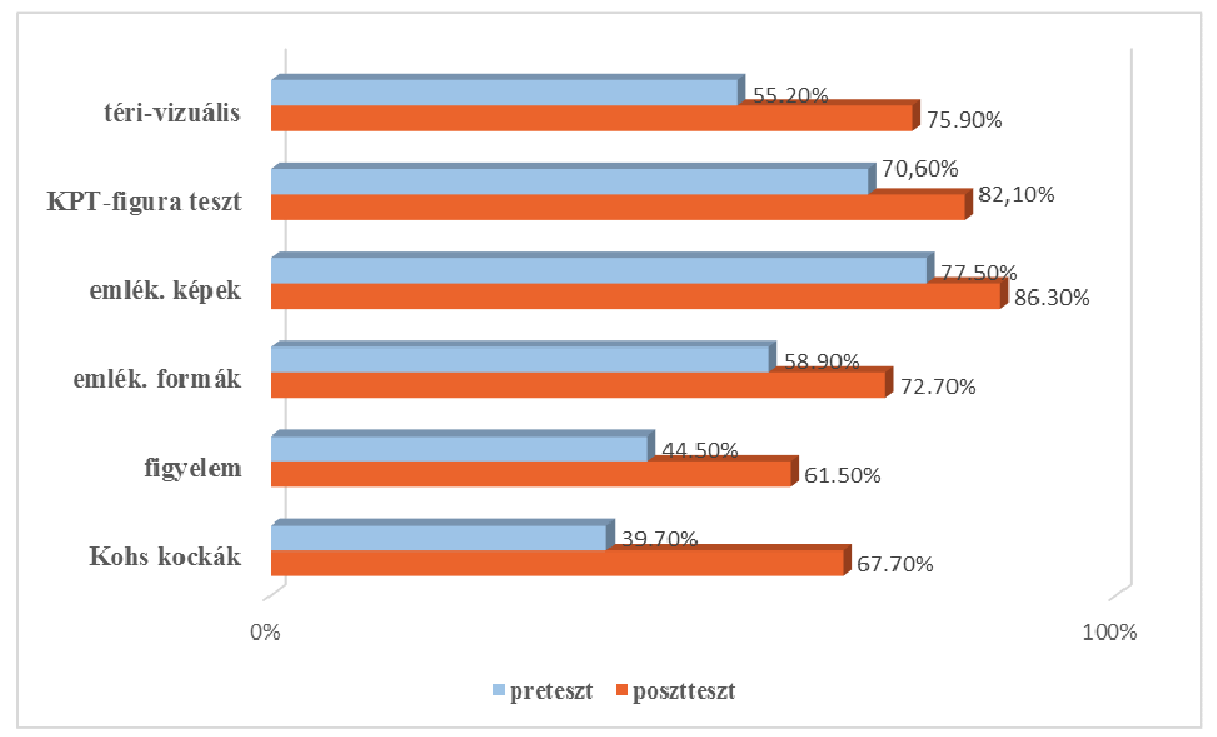

3. táblázat: Matematikai teljesítményt megalapozó képességek területén bekövetkezett fejlödés szignifikancia szintje (forrás: a Szerzők)

\begin{tabular}{|c|c|c|c|c|c|c|}
\hline Statisztika & $\begin{array}{c}\text { Téri- } \\
\text { vizuális }\end{array}$ & $\begin{array}{c}\text { KPT } \\
\text { Figura teszt }\end{array}$ & $\begin{array}{c}\text { Emlék. } \\
\text { képek }\end{array}$ & $\begin{array}{c}\text { Emlék. } \\
\text { formák }\end{array}$ & Figyelem & Kohs kockák \\
\hline M(Preteszt ) & $55.20 \%$ & $70.60 \%$ & $77.50 \%$ & $58.90 \%$ & $44.5 \%$ & $39.70 \%$ \\
\hline M(Posztteszt ) & $75.90 \%$ & $82.10 \%$ & $86.30 \%$ & $72.70 \%$ & $61.5 \%$ & $67.70 \%$ \\
\hline $\mathbf{t}$ & 6.8078 & 3.3159 & 1.4947 & 2.4405 & 10.0019 & 7.2082 \\
\hline $\mathbf{p}$ & $<0,01$ & $<0,01$ & $>0,05$ & $<0,05$ & $<0,01$ & $<0,01$ \\
\hline
\end{tabular}

Eredményeink szerint első hipotézisünk, amely szerint: "egy intenzív, táblajátékokra támaszkodó fejlesztő program jelentősen javítja a 4-5. osztályos hallássérült tanulók térivizuális képességeit, gondolkodási képességeit, vizuális emlékezetét és figyelmét", teljes mértékben beigazolódott.

A 4. táblázat az alapvető matematikai képességeket mérő feladatokban elért egyéni pre- és posztteszt átlagteljesítményének összehasonlítását tartalmazza.

4. táblázat: Alapvetö matematikai képességek egyéni pre- és posztteszt átlagteljesítményének összehasonlító táblázata (forrás: a Szerzők)

\begin{tabular}{|l|c|c|c|c|c|}
\hline \multicolumn{1}{|c|}{ Teszt } & $\mathbf{n}$ & $\mathbf{M}$ & SD & t & p \\
\hline Preteszt & 10 & 38.7 & 15.25 & \multirow{2}{*}{12.0742} & \multirow{2}{*}{0.0001} \\
\hline Posztteszt & 10 & 43.1 & 15.18 & & \\
\hline
\end{tabular}

A pre-és posztteszt átlagteljesítmény közötti különbség nem annyira nagy, mint a matematikai teljesítményt megalapozó képességek terén, viszont a $t$ és $p$ értékeknek megfelelően ezen a területen is szignifikáns a fejlödés $(p<0,01)$. A táblajátékokra épülö 
beavatkozás hatására jelentősen javult tehát az alapvető matematikai képességek terén is a hallássérült diákok teljesítménye.

A 3. ábra a felmért alapvető matematikai képességek terén, pre- és poszttesztben elért, képességekre lebontott átlagos csoportteljesítményt összegzi. Amint a 3. ábrán látható, minden képesség terén fejlődés tapasztalható, a legjelentősebb a logikai számsorok terén (17,5\%-os fejlődés).

3. ábra: Alapvetö matematikai képességek terén elért átlagos csoportteljesítmény pre-és posztteszt eredményei (forrás: a Szerzők)

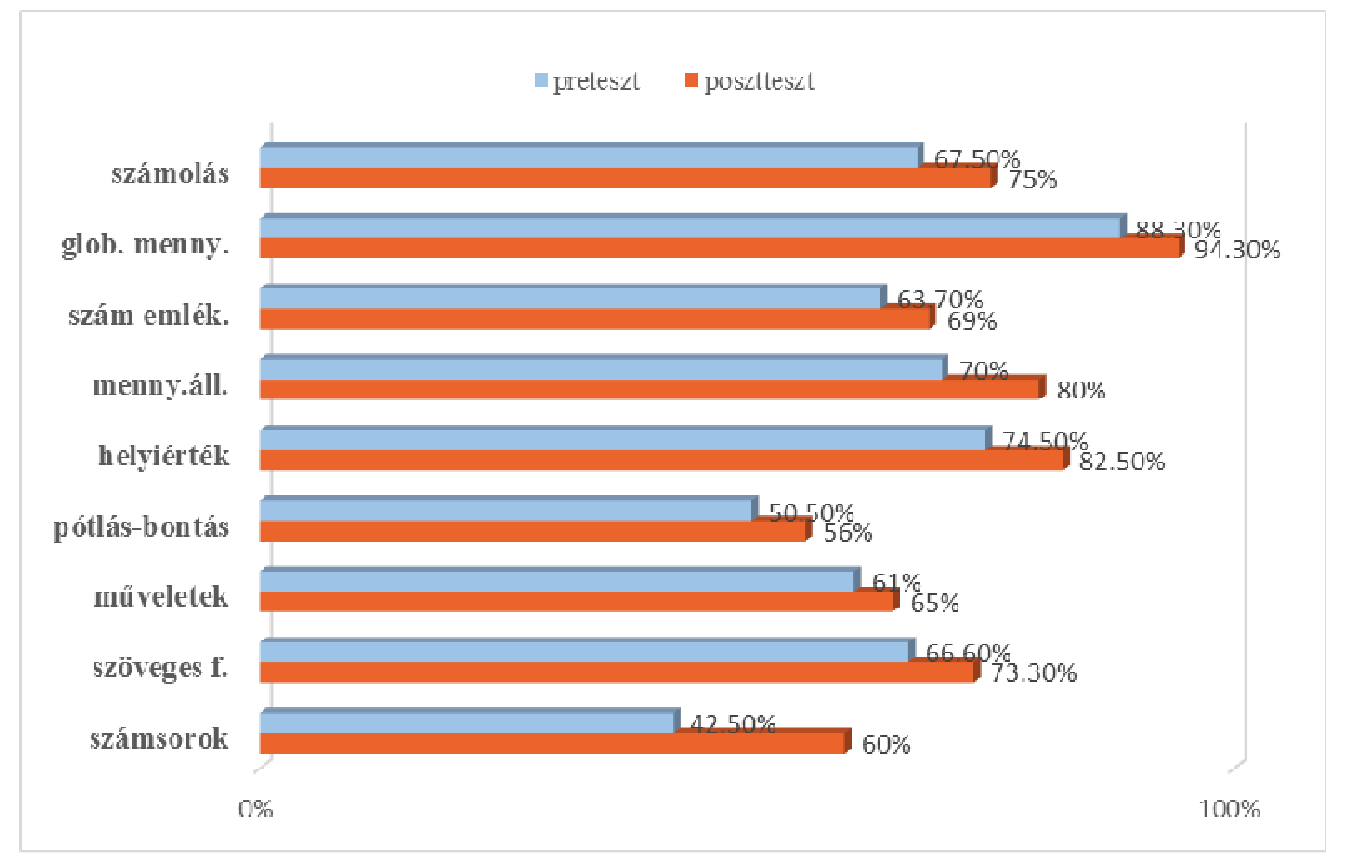

A különböző alapvető matematikai képességek területén bekövetkezett fejlödés szignifikanciájának leellenőrzése céljából t-próbát alkalmaztunk, képességenként összehasonlítva a pre- és poszttesztben elért egyéni eredményeket. A vizsgált alapvető matematikai képességek esetében 5 területen tapasztalható szignifikáns fejlődés: a számolás $(p<0,05)$, helyi érték $(p<0,01)$, pótlás-bontás $(p<0,01)$, müveletek $(p<0,05)$ és logikai számsorok $(p<0,01)$ terén.

A fent összegzett eredmények alapján megállapítható, hogy:

- az alapvető matematikai képességeket vizsgáló feladatok terén a vizsgált 4.-5. osztályos hallássérült diákok közepes teljesítményt értek el (64,5\% a pretesztben),

- a táblajátékos fejlesztő program hatására szignifikánsan javult a diákok alapvető matematikai képességeket vizsgáló feladatokban nyújtott teljesítménye (a kilenc felmért alapvető matematikai képesség közül öt képesség terén szignifikáns a fejlödés).

Eredményeink szerint tehát második hipotézisünk, amely szerint: “az intenzív, táblajátékokra épült fejlesztő program hatékonyan befolyásolja a hallássérült diákok alapvető matematikai képességeinek (numerikus bázisképességek) alakulását és a matematikai tantárgyi eredményességet”, beigazolódott.

\section{Konklúziók}

A táblajátékok a hallássérült tanulók gondolkodásfejlesztésének kiváló eszközei. Lehetőséget biztosítanak a matematikai kompetencia készség- és képességkomponenseinek hatékony 
fejlesztésére. Hatékonyságuk tetten érhető a téri-vizuális képességek, vizuális memória és figyelem, analízis, szintézis, kombináció, figurális absztakció, valamint az alapvető matematikai képességek (mennyiségállandóság, számolás, pótlás-bontás, müveletek) fejlődése terén, jelentősen megkönnyítve és javítva a tantárgyi ismeretek elsajátítását. Alkalmazásukkal olyan tanulási környezetet tudunk biztosítani, amely a nyelvi hátrány ellenére, a tanulás szempontjából releváns problémákat, feladatokat kínál, ahol a tanuló önállóan jut el az ismeretekhez. A tanuló nem csak a szabályok mechanikus bevésésére törekszik, hanem keresi a lényeget, ismeretei állandóan fejleszthetőek, előhívhatóak, mozgosíthatóak, alkalmazhatóak lesznek.

Használatuk színesebbé, vonzóbbá, tartalmasabbá teheti a matematika órák tevékenységeit. A játékcsaládok nagyszerü lehetőségeket nyújtanak a különböző témakörök feldolgozásához. Például: a Blokus területszámításra, százalékszámításra, számalkotásra, helyiérték gyakorlására alkalmas, a „mancala” pedig a globális mennyiségfelismerés, becslés, egyenlő részekre való bontás, a szorzás gyakorlásának kiváló eszköze.

\section{Irodalom}

Csíkos, Cs. (2007): Sakk, metakogníció és kezdö-szakértő problematika, Hadmérnők, különszám

Duró, Zs. (2007): A sakk képességfejlesztö hatásainak vizsgálata. Új Pedagógiai Szemle 2000/9

Garcia R. R. és Abed Z. L. (2010): The Mind Lab methodology to develop skills in 5th-Year students in Elementary Schooling. Teaching for the 21th Century, Research Studies by MIND GROUP

Gyarmathy É. (2009): Kognitív Profil Teszt, Iskolakultúra, 3-4 sz.

Juhász, Á. és Dékány J. (2007): Kézikönyv a diszkalkulia felismeréséhez és terápiájához. Budapest, Logopédiai Kiadó

K. Nagy E. (2012): Tehetségfejlesztés táblajátékkal, Fókusz, XIV évfolyam 1.szám, 2012

K. Nagy E. (2014): Gondolkodásfejlesztés táblajátékokkal, Magyar Tehetségsegítő Szervezetek Szövetsége, Géniusz Könyvek

Kohs, S.C. (1920): The Block Design Test, Journal of Experimental Psychology, 1920/3

Kozhevikov, M., Hegarty, M. és Mayer, R. (2002): Students' use of imagery in solving qualitative problems in kinematics. In M. Anderson (Ed.), Diagrammatic Representation and Reasoning . London

Krajcsi, A. (2010): A numerikus képességek zavarai és diagnozisuk, Gyógypedagógiai Szemle, 2010/2 sz.

Marshark, M. (2003): Cognitive functioning in deaf adults and children. In. Marschark M..\& Spencer P.E. (Ed): Oxford Handbook of Deaf Studies, Language and Education, Oxford University Press

Mészáros, M. (2013): 50 táblajáték - matematikai feladat, Hejökeresztúr

Nagy, J. (1998): Kognitivizmus és az értelem kimüvelése. In Iskolakultúra 1998/2 sz..

Nunes, T. \& Moreno, C. (2002): An Intervention Program for Promoting Deaf Pupils Achivement in Mathemetics., Journal of Deaf Studies and Deaf Education , 7(2)

Skemp, R. (2005): A matematikatanulás pszichológiája, Edge 2000 Kiadó, Budapest

Stiles, J. (2013): The Development of Visuospatial Processing. Comprehensive Developmental Neuroscience: Neural Circuit Development and Function in the Brain, 2013/3

Szentiványi, T. (2000): A kreativitás fejlsztése játszással és játékok segítségével, Új Pedagógiai Szemle, 2000/ 7/8 sz. 
Vidákovich, T. és tsai (2008): Matematikai kompetenciaterület - szakmai koncekpció. Educatio Kht, Budapest

Wilson, B. G. (1995): Metaphors for Instruction: Why we talk about learning environments? Educational Technology, Vol. 35. Issue 5

Wood, D., Wood, H., és Howarth, P. (1983): The mathematical achievements of deaf children from different educational environments. British Journal of Educational Psychology, 54

\section{Internetes hivatkozások}

Ceglédi, I. (2011): Kompetencialalpú matematikaoktatás, EKF (digitalis tankönyvtár). Letöltés: 2015.12.10. Web: http://www.tankonyvtar.hu/hu/tartalom/tamop425/0038_ matematika_Cegledi2/ch01.html

Mészáros, M. (2014): Táblajátékok és matematikai kompetenciák. Letölktés: 2015.12.01. Web: http://meszaros-mihaly.hu/tablajatekok-es-matematikai-kompetenciak-1/

Nagy, L. (2000): A barlangrajzoktól a display-ekig avagy a táblások ma is köztünk vannak... UJALAP www.tablajatekos.hu 


\title{
TEHETSÉGBÖL - KIVÁLÓ. \\ KUTATÁS KÖZBEN: A KÜLFÖLDÖN MUNKÁT VÁLLALÓ, FIATAL DIPLOMÁS NŐK ÉLETKEZDÉSI ESÉLYEI
}

\author{
Szerző: \\ Schranz Edit \\ Debreceni Egyetem
}

Szerző e-mail címe:

sedit@t-online.hu

\section{Lektorok:}

Czibere Ibolya

Debreceni Egyetem

Szekeres Melinda

Debreceni Egyetem

Mező Katalin

Debreceni Egyetem

Szilágyi Barnabás

Debreceni Egyetem

Schranz Edit (2015): Tehetségböl - kiváló. Kutatás közben: a külföldön munkát vállaló, fiatal diplomás nők életkezdési esélyei. Különleges Bánásmód, I. évf. 2015/2. szám, 17-35. DOI 10.18458/KB.2015.2.17

\begin{abstract}
Absztrakt
Jelen tanulmány arra keresi a választ, vajon kivételes adottság és kemény tanulás, munka, vagy bátorsággal kevert fiatalos lendület, szerencse, esetleg mindez együtt az, ami lehetövé teszi a 2010-es évek huszonéves, diplomás fiataljai számára, hogy Európa munkaerőpiacán inkább megtalálják a számításaikat. Minta: $n=28$ (22-35 éves) nö. Módszer: félig strukturált interjú. Eredmény: bár minden, általunk készített interjú különösen egyéni életutat mutat, mindegyikröl elmondhatjuk, hogy kemény tanulás, kivételes, tehetséggel párosult szorgalom jellemzi ezeket a fiatalokat. No meg az is, hogy e kis mintában körülbelül 98 százalékuk vágta rá a célzott kérdésre: most úgy látja, soha sem fog visszatérni.
\end{abstract}

Kulcsszavak: tehetség, felsőoktatás, Bologna, diplomás fiatal nők, külföldi munkavállalás, munkaerőpiac

Diszciplínák: szociológia, pszichológia

\footnotetext{
Abstract

EXCELLENT AT BEING TALENTED. RESEARCH: YOUNG GRADUATE WOMEN LIFE STARTING CHANCES OF WORKING ABROAD

This study seeks to determine whether it is exceptional talent and hard work, or courage mixed with young energy and luck, maybe all these together, that makes it possible for young adults with a fresh diploma in the 2010's to find their future in Europe's labor market. Sample: $n=28$ (22-35 years old) women. Method: semi-structured interview. Results: even though all the interviewees are unique, all the participants can be said to have a few things in common; persistent study and exceptional diligence paired with talent. There is, however,
} 
one more thing shared across $98 \%$ of interviewees in our research sample; when asked if they will come back to Hungary, they answered without hesitation that they didn't think they ever would.

Keywords: talent, higher education, Bologna, young women graduates, work abroad, labour market

Disciplines: sociology, psychology

Az értelmiségi, tehetséges fiatalok külföldre távozása, európai, vagy távolabbi munkavállalása jelentős kérdés a gazdasági versenyképesség céljait, a társadalom jövőjét tekintve. Aki elmegy és a végzettségének megfelelő státuszt szerez valamely európai ország munkaerőpiacán, annak jelentősége nemcsak abban van, hogy megfelelö nyelvtudás és szakmai kompetenciák nélkül nem kerülhetett volna a jelenlegi helyére, hanem abban is, hogy az állásért az adott ország helybéli, fiatal diplomás elitjével is versenyre kelt a posztért. Mindez azt feltételezi, hogy a képzése, a munkaerö-piaci felkészülése során olyan tudást, kompetenciát sajátított el, amely felerősítette az egyébként a tanulás folyamatában - mint később látni fogjuk - egyértelműen megmutatkozó tehetséges személyiséget. Függetlenül attól, hogy milyen társadalmi státuszú család gyermekeként került oda, ahol jelenleg tart. A témával sokan foglalkoztak előttünk - igaz, nem egészen az általunk vázolt aspektusban. A tehetséggel, amely az oktatás folyamatában figyelmet érdemel az iskolakultúra, illetve a pszichológia oldaláról - a hazai szerzők közül például - Balogh László, Czeizel Endre, Csermely Péter, Gyarmathy Éva, Mező Ferenc tanulmányait említhetjük. A külföldi szerzők közül Renzulli, Mönks, Gardner nevét említenénk. A magyar fiatalok külföldi munkavállalásával, a migrációval kapcsolatban számos tanulmány látott napvilágot az utóbbi években, például Sík Endre, Róbert Péter, Kolosi Tamás munkái. Azonban az elsők között készül olyan kutatás, amely kis mintán ugyan, de életút-interjúkon keresztül igyekszik feltárni a külföldi munkavállalás és letelepedés okait, nem szakmaspecifikusan. Megjelenik benne a családi háttér, mint a tanulási és érvényesülési hátráltató - és előnyöket megmutató tényező -, s az összehasonlítás az adott szakmák hazai jövedelmi lehetőségeiről és az ebből következő életkezdési lehetőségekről. A vizsgálatban célzottan nem az egészségügyben dolgozók halmazát kívántuk megszólítani, hanem a szerte Európában elhelyezkedett más, vegyes szakmák lehetőségeit kívántuk feltérképezni. A kutatás ugyanakkor igyekszik a mintán keresztül képet adni a kint elhelyezkedő fiatalok élethelyzetéről, integrációjáról, továbblépési, továbbtanulási lehetőségeiről, jövőképéről - és arról, van-e értelme megkérdezni: szándékozik-e hazahozni a tudását? Dolgozatunk első részében tehát igyekszünk képet adni a felsőoktatásban fellelhetö kiegyenlítetlen viszonyokról - amelyet a Bologna-folyamat tükrében vizsgálunk. Majd pedig az elmúlt 1-2 évben elkészült vizsgálatok eredményeit, valamint saját, éppen folyamatban lévő kutatásunk eddigi részeredményeit kívánjuk összefoglalni a külföldön dolgozó magyar fiatalok - elsősorban nők - életkezdési esélyeinek vizsgálatáról.

\section{A tehetségröl}

Kivételesség és társadalmi hasznosság. A számos, tehetségekről szóló elmélet alapján ebben a két szóban foglalhatjuk össze azt a komplexitást, amelyet a talentum, mint jelenség, mai gondolkodásunk értelmében jelenthet. A kivételesség, a tehetség szó tekintetében, magában rejti a kreatív gondolkodást, a megfelelö motiváltságot és ennek eredményeként az átlagon 
felüli eredményt, teljesítményt. Míg Joseph S. Renzulli az átlagon felüli képességet, a feladat iránti elkötelezettséget, valamint a kreativitást emelte be ismertté vált háromkörös modelljébe - amely három dimenziónak közös része adja nézete szerint a tehetséget -, addig Franz J, Mönks, elfogadva Renzulli elméletét, kiegészítette azt a család, az iskola, s a kortárscsoport háttérben szerepet játszó háromszögével, amely szerinte meghatározza a tehetség kibontakozását (Balogh, 2006). Mönks így azt mondja, hogy a tehetség fejlődése, kibontakozása nagymértékben függ a támogatói környezettől. Ennek ismeretében talán nem lehet véletlen, hogy például az angol nyelv három külön szót is használ a tehetség megkülönböztetésére. „Giftedness” - amelynek értelmében Renzulli is vizsgálta a tehetség szót, s amely a potenciális tehetséget, annak ígéretét jelöli. „Talented” - amellyel a már felismert tehetséget hívja az angol, valamint a „genius”, amelyet a kivételes képességekkel megáldott, különleges szellemi képességekkel rendelkező emberekre használ. Mindezekre épülve szoktuk megemlíteni a Czeizel-féle $4 \times 2+1$ faktoros sors talentum-modelljét, amely négy kör közepére helyezi a talentumot, s amely 4 adottságból (értsd örökletességböl) tevődik össze: speciális mentális, általános értelmesség, kreativitás, motiváció. E mögött áll a Mönks-féle háttér és befolyásoló tényező, mint a család, az iskola és a kortárscsoportok, ám megjelenik mellette a +1 faktor, amelyet Czeizel sorsfaktornak nevezett el, mert számol az egyén életében a betegségekkel, a devianciákkal és a korai halálozás lehetőségével is (Czeizel, 2003).

A tehetség tehát a kreativitás, motiváció, átlagon felüli teljesítmény képességével s a környezete támogató hátterével érheti el, hogy helyet találjon a felsőoktatási képzésben, ám mindehhez a megfelelő intelligencia is elengedhetetlen, hiszen a környezethez alkalmazkodás képessége fontos része az önmenedzselésnek. Mindez azonban „hozható, tanulható, tanítható” (Bodná, 2011). A cél valójában az, hogy a hallgató mind jobban tudja magát - a saját érdekeit érvényesíteni, képviselni a munkaerö-piacon, a meglévő és a megszerzett tudás birtokában. Ezzel részben összecseng az Európai Felsőoktatási Térséget létrehozó Bologna-folyamat célkitüzése, amely azon kívül, hogy az európai munkaerö-piachoz illeszkedő képzés megteremtését vette célba, a tömegképzésen belül az elitképzés kereteinek előkészítését is megalkotta (KSH 2009) - amely elitképzésbe a tehetségek, a kiválóan tanuló és tejesítö diákok halmaza éppúgy beletartozik, mint azon fiatalok csoportja, akik a szüleik által megfizetett kiváló iskolák nyomán váltak az elitképzés résztvevőivé. Mindkét halmaz ugyanazon a munkaerőpiacon kíván ringbe szállni a jól fizető állásokért. A kérdés az, mi dönti el, hogy kinek lesz elég tehetsége bejutni és megtartani a pozícióját? Hiszen, ha hihetünk Czeizel Endre és a Mönks-féle háttér fontosságának, akkor hihetünk abban is, hogy a körülmények is közrejátszanak abban, ki, mit ér el, legyenek bár azonos képességeik, ám eltérő feltételeik az induláshoz.

\section{Bolognából - európába}

Mi történik akkor, amikor a tehetségnek nem elég az egyetemi környezete, a szakkollégiumi támogatás? Az Egységes Európai Felsőoktatási Térség létrehozói számára épp az a gondolat játszotta az egyik fö szerepet, hogy a diákok számára az ösztöndíjak elnyerésével még inkább kinyissák a teret - mind a tanulásra, mind az egységes európai munkaerőpiacra (Hrubos, 2012). A 2005-ben, az Egységes Európai Felsőoktatási Térséghez csatlakozó országokban bevezetett bolognai rendszerü képzés létrehozói, kifejezetten a képzési szerkezet megváltoztatásában látták megoldottnak az expanzió, valamint a növekvő munkanélküliség kérdését. A kettő, illetve valójában háromciklusú képzés (alap-, mester- és PhD-képzés - a bolognai rendszer alapján) bevezetésétől várták egyrészt a munkaerö-piaci illeszkedés pozitív változásait, másrészt a tömegképzésen belüli elitképzés kereteinek felállítását - mintegy 
válaszként a felsőoktatási képzés volumenét és szerkezetét mozgató társadalmi, gazdasági, politikai tényezők fejlődést, továbblépést sürgető kérdéseire (Gábor és Szemerszki, 2006).

Azonban mi történik akkor, amikor a Bologna-folyamat deklarált célja - hogy tudniillik Európa munkaerőpiacára képezzük a diákokat - valóban beteljesíti ezt a feladatot, s a tehetséges, jó képességü hallgatók el is mennek? S mint később a saját kutatásunk példáin keresztül látni fogjuk, olykor annak ellenére is, hogy a szülői, támogatói háttér nem feltétlenül ideális a felsőfokú tanulmányok elvégzéséhez. S valójában csak a diákon, a tehetséges tanuló kitartásán, szorgalmán és akaratán múlik, hogy belevág-e a nehézségek ellenére a felsőfokú tanulmányokba. Itt tartjuk fontosnak megjegyezni, hogy alternatív megközelítés szerint az iskolarendszerben felfelé haladva elméletileg csökken a származás hatása. Egyrészt, mert minél idősebb egy diák, annál kevésbé számít a családi háttér - fogalmazza meg az AlwinThornton-féle „életciklus-hipotézisre” építve Róbert Péter (Társadalmi mobilitás, 53.). Másrészt a képzési hierarchia magasabb szintjén a tanulók erősen szelektált csoportját találjuk - szelekciós folyamat hipotézise -, amely csoport esetében a származás jelentősége egyre kisebb. Mint azt a Robert Mare által kidolgozott rendszerből kiolvashatjuk (1981). Mare arra, az oktatási rendszerben meglévő vertikális rendre (hierarchiára) alapozta módszerét, amely szerint a magasabb iskolai szintre lépés feltétele az alacsonyabb szint teljesítése (az általános iskolai bizonyítvány szükséges a középiskolai felvételhez). Így dolgozta ki a feltételes valószínüség elemzési módszerét, amely a származás hatását lépésről lépésre követi az egyes iskolai szinteken (Róbert, 1990).

Az oktatási expanzióval azonban, amikor egyre többen jutnak el a magasabb tanulmányok szintjére, a szelektivitás hatása csökken, a származásé növekszik - Mare ezzel magyarázta, hogy az amerikai társadalomban nem csökkent a származás hatása a magasabb iskolai szinteken (Róbert, 2001, 54.). Hrubos Ildikó tanulmányában szintén az oktatási expanzió hatásaiból indul ki ezzel kapcsolatban, amely nemcsak tényszerủen megváltoztatta a hallgatók társadalmi összetételét a felsőoktatásban, de átalakításra kényszerítette a felsőoktatási intézmények körét is. A társadalmi-gazdasági igények különbözőségei, a megváltozott viszonyok, bizonyos szakokon a hallgatók kegyeiért folytatott és más, erőforrásokért folytatott küzdelem hatására az intézmények is differenciálódtak. A változás egyrészről a különböző funkciók, missziók szerinti, horizontális differenciálódás, másrészről a presztízs szerinti, hierarchikus diverzitás megjelenése felé hatott. (Hrubos, 2012). Azonban ne feledjük, hogy ezek az intézményi változások pusztán következményei az átalakulásnak. Az Egységes Európai Felsőoktatási Térség létrehozásának igazi célja Európa gazdasági és „akadémiai” versenyképességének megőrzése és megerősítése, valamint a hallgatói, majd később a munkaerőpiac fiatal szereplőinek mobilitása volt, és az ma is. A diplomák akadálytalan kölcsönös elismerése folytán, elméletben tehát, a lehetőségek tárházát nyitotta meg a tanulni vágyó és az európai munkaerőpiacon versenybe szálló fiatalok előtt. Igaz, az alap- és mesterképzés közötti ,átmenet” - ahogy Hrubos Ildikó tanulmányában fogalmaz - mint „társadalmi szelekciót tartalmazó lépcső” már igen hamar megmutatta a Bologna-folyamat intézményi, szerkezeti kereteivel létrejött társadalmi egyenlőtlenséget. Ugyanakkor a hallgatói mobilitás Európa országai között is aránytalan. Mivel az utazás szintén az anyagiak függvénye, ám a keleti országok diákjainak a nyugati országokban végzett egyetemi szemeszterek vonzóbbak, mint fordítva, ezért - viszonylag gyorsan - megkezdődött az „agyelszívás” első lépése, amely - Hrubos szerint - nemcsak a kibocsátó országokra, de az európai földrészre nézve is veszélyes lehet a távlatokat tekintve. A fizetős szakok bevezetése pedig egyértelmúen kizáró hatással volt azokra a diákokra, akik nem engedhették meg maguknak, hogy a motivációban esetleg kívánt, de anyagilag elérhetetlen szakokon tanuljanak. Itt utalnánk vissza Mare említett gondolataira, a származás hatásait elemző teóriájára, amely jelen esetben, napjaink Európájában, az eredetileg felállított célok ellenére mégiscsak meghatározza, hogy a bolognai rendszer mely szakán és fokán képes tanulni a 
fiatal - hiszen megfelelöen kondicionált háttérrel - az átjárható kreditrendszer miatt valóban bármely egyetem elérhető. Ugyanakkor fontosnak tartjuk megjegyezni, hogy a későbbiekben vázolt empirikus kutatásunk első eredményei között éppen az tünik ki, hogy az Európa országaiban felvehető diákhitelek rendszere épp a tehetséges fiatalok érvényesülési lehetőségét segíti - mint azt példával is bizonyítani kívánjuk majd. Igaz, ez egyben nemcsak azt a kényelmetlen helyzetet határozza meg, hogy jelentős - több tízezer eurós - adóssággal indul neki egy huszonéves fiatal a jövőjének, hanem azt is, hogy hol kell ahhoz munkát vállalnia, hogy a fizetési kötelezettségét teljesíteni tudja. Igen nagy az esélye annak, hogy nem Magyarországon, hanem valahol... Európában, különben a külföldön felvett diákhitelt, amelyre elkötelezte magát, nem tudná visszafizetni. Európában, Angliában él az a lehetőség, hogy addig nem kell elkezdenie a törlesztést az egyetem felé egy diáknak, amíg egy bizonyos szint fölé nem emelkedik a fizetése (Cambridge). Más országokban nem ilyen megengedő a rendszer, Spanyolországban például a mesterképzésre felvett diákhitelt minden körülmény között el kell kezdeni visszafizetni - függetlenül attól, hogy jól vagy rosszul fizetett állásban tud elhelyezkedni a fiatal. Ilyen helyzetben valóban az átlagnál jobb képességekkel kell rendelkeznie ahhoz egy magyar fiatalnak - megfelelő szülöi háttér nélkül -, hogy ezeket a terheket vállalja az önálló életkezdés küszöbén.

\section{Túlképzettek csapata - vagy mégsem?}

A 2012-es év második felében, a fiatalok körében végzett kutatási adatok - már nem elöször - arra engedtek következetni, hogy a fiatalok „túlképzettek” a magyar munkaerőpiacra. Gazsó Tibor tanulmányában többször is kiemeli ugyanakkor, hogy Magyarországot illetően fontos: nem hozhatjuk összefüggésbe általánosságban a „felülképzettséget”, a diplomás munkanélküliség jelenségével, illetve azzal a ténnyel, hogy a gazdasági válság hatására a diplomások álláskeresési ideje megnőtt. A tanulmány arra hívja fel a figyelmet, hogy a gond egyik része a felsőoktatási kibocsátás szerkezeti problémájából adódik. Mondhatnánk rögtön, hogy „még mindig”, bár a Bologna-folyamat bevezetése óta már 10 év telt el. Gazsó Tibor kutatásai szerint a 2012-ben, a nem dolgozók-nem tanulók csoportjába tartozók több mint egyharmada mindössze általános iskolai végzettséggel rendelkezik. Egynegyedük szakiskolát vagy szakmunkásképzőt végzett. Ezen fiatalok fele a legidősebb vizsgált korcsoportba, a 2529 évesek csoportjába tartozik és a tanulmány szerint 42 százalékuk községi lakos. A számokat elemezve Gazsó Tibor a következőket írja tanulmányában: „,...az adatok világosan jelzik, hogy a magyar társadalomban a gazdasági aktivitás leépülésével perspektíva nélkül maradt, vidéken élö, alacsony iskolai végzettségü csoportok körében töretlenül újratermelödik a halmozottan hátrányos társadalmi helyzet, amelynek egyik fö ismérve a munkához jutás rendkiviuli nehézsége (Gazsó, 2012, 141.).”

A kép különösen akkor disszonáns, ha megnézzük a magyarországi diplomás kutatások adatait (Gazsó, 2012; Magyar Ifjúság Tanulmánykötet, 2012) amelyek szerint ugyanakkor, amíg 2008-ban 3\% volt a felsőfokú diplomával elhelyezkedési nehézségekkel küzdö pályakezdők aránya, addig ez az arány 2012-re 10\%-ra emelkedett. Méghozzá úgy, hogy közben a felsőoktatásban felvett hallgatók száma már a megelöző évektöl csökkenőben volt. Az adatok szerint (Veroszta, 2013; Eurostat, 2012) például a 2012-es évben több mint 20 ezer diákkal kevesebbet vettek fel a felsőoktatásba, mint az azt megelőző két évben. Vagyis a két jelenség, bár teljesen eltérö, társadalmi csoportokról szól, abból a szempontból mégis elgondolkodtató, amennyiben a fiatal generációk perspektíváit erősen egy irányba, az értékvesztés, a kilátástalanság irányába tolja. Az értékvesztés jelenségén gondolkodik el Ságvári Bence „Az átmenetek kora? - A magyar fiatalok társadalomképéről” címü tanulmányában is. Ságvári arra hívja fel a figyelmet, hogy ez a fiatal korosztály a legsérülékenyebb. A sikeres vagy sikertelen munkaerő-piaci integráció a felnőtté válás első 
lépéseinél, az önálló életkezdési körülmények kialakításánál, a korábbi szocializációtól függetlenül is jelentős hatással lehetnek a fiatalok gondolkodására. Beleértve ebbe a társadalommal, gazdasággal, politikával kapcsolatos értékek kialakulását és megszilárdulását. Márpedig ahhoz, hogy az ezen fiatalok által képviselt normák értékek és attitüdök együttese a későbbiekben valódi értéket jelentsenek a társadalom számára, nem mindegy, hogy a korosztály társadalmi integrációjához kötődő „értékszerkezet” milyen keretet ad, hiszen ez határozza meg a későbbiekben a társadalom, a gazdaság és a politika fejlődését.

\section{Bizalomból elégséges}

Ságvári Bence empirikus kutatása szerint a magyarországi fiatalok szemléletét európai uniós összehasonlításban nézve két szembetünő eltérés jellemzi: a normaszegés nemcsak a gazdasági sikerekhez, hanem a mindennapi élethez is szükséges. Fontosnak tartjuk megjegyezni, hogy ez a szemlélet nemcsak a felsőoktatásban tanulókra jellemző, hanem - a tanulmány szerint - általában a magyar fiatalokra. Ez egyértelmü bizonyítéka az értékválságnak és a bizalomvesztésnek. Ha folytatjuk a szerző gondolatsorát és hivatkozunk a tanulmányban leírt elméleti megközelítésekre, ugyancsak elgondolkodtató következtetésekre jutunk: az elméletek szerint ugyanis a bizalom erősíti az egyén közösséghez tartozását, ugyanakkor nem jelenti más csoportok kirekesztését. A bizalom hiánya viszont a társadalmi tőke erodálásához vezet, amelynek végén izoláció, a szerkezetek felbomlása áll. Nem müködnek a kommunikációs csatornák és elindul az emberi kapcsolatok hanyatlása, elindul a rémhírek terjesztése, megerösödnek az elöítéletek, sztereotípiák. Feltehetnénk a kérdést, hogy hogy jön mindez a felsőoktatás és a munkaerőpiac kapcsolatához, de ha a bizalom, mint társadalmi érték oldaláról gondoljuk tovább a fent leírtakat, gyorsan megtaláljuk a választ. Hiszen - mint arra a tanulmány is kitér - a bizalom rendkívül fontos a fennálló társadalmi rend, illetve a társadalom szervezeti müködésének átláthatósága miatt, amelynek egyik legfontosabb eleme a kiszámíthatóság. Ez ad stabilitást a munkahelyeknek és anyagi stabilitást a társadalom tagjainak. A bizalom tehát - állapítja meg írásában Ságvári Bence kihat a gazdasági szemléletre, a társadalom normatív összetartó erőinek jellegzetességeire. Nos, egyből látjuk, hogy ez az a pont, ahol a bizalom kérdése illeszkedik felsőoktatás és a munkaerőpiac kapcsolatához, hiszen nem mindegy, hogy a fiatal felnőttek milyen értékeket fogadnak el. Az értékek alakulását pedig kétséget kizáróan a szülő, a kortárscsoportok és az iskola, pontosabban az oktatás - így a felsőoktatási képzés - képes befolyásolni. Ezt a nem magától alakuló értéksort egészíti ki a fiatal a saját élettapasztalatival. Az így formálódott értékrend az, amely a társadalomban szemléletváltozást képes előidézni. Nem véletlen ahogy Ságvári Bence tanulmányából kitủnik: a szemléletváltás gyakran esik egybe a generációváltással. Ennek a kijelentésnek a tükrében válik érdekessé, hogy tanulmányban idézett Europien Socal Survey egyik eredménye szerint: a fennálló politikai-gazdasági rendszerrel a magyar fiatalok átlagos elégedettsége 52 pont volt, amely európai uniós összehasonlításban nagyon alacsony (legalacsonyabb) indexnek minősül. Az elégedettséget mérő index átlagos értéke a teljes ESS mintában 58, míg a 15-29 éves fiatalok esetében 60 pont volt. E korosztály átlagos értékei 85 (Finnország) és 30 (Görög ország) pont között változtak). Ugyanakkor ez az eredmény nem független a társadalom egészének véleményétől, vagyis ennek megfelelően nincsenek a felmérés szerint generációs különbségek. Mit jelenthet mindez? Talán azt, hogy a mai magyar fiatal generációk éppen olyan „sötétnek” látják a saját jövőjüket, a meglevő tapasztalataikkal, mint a sokat tapasztalt idősebb generációk? Vagy mindössze annyi történik, hogy az idősebbek a szokásosnál jobban hatnak a fiatalok gondolkodására? Mi lehet az oka annak, hogy gondolkodásban, életérzésben, helyzetfelismerésben összeérnek ezen a ponton a generációk Magyarországon? - ahogy Ságvári Bence írja, a fiatalok ,a válság okozta bizonytalansággal „hozzáöregedtek” a 
szüleikhez. A választ, Ságvári a tanulmányában nagyon világosan levezeti: a gazdasági visszaesés illetve stagnálás, valamint a következő évek lassú kilábalása nem ígér gyors, pozitív változásokat a magyar fiatalok életében. Mindez azt jelenti, hogy a közeljövőben a munkaerő-piacra kilépő fiatalok általános generációs élményévé válhat a válságtudat és a bizonytalanság. Akkor is így van ez - írja a tanulmány -, ha időközben jelentősen átszerveződött a felsőoktatás épp annak érdekében, hogy a munkaerőpiac közelebb kerülhessen a felsőoktatási kibocsátáshoz.

Nos, mindezek tükrében talán nem meglepő, hogy a fentebb említett nehézségek, körülmények nem tették/nem teszik feltétlen vonzóvá a Magyarországon elérhető lehetőségeket az életkezdési esélyek szempontjából a fiatal korosztály számára. Különösen a tehetséges, jól tanuló, alkalmazkodásra képes, könnyen váltó fiatalok számára lett vonzó célpont a nagyobb stabilitást, a munkáért megbecsülésként értékelhető, jobb életszínvonallal kecsegtető európai országok - mint azt majd a későbbiekben a saját kutatás alapján látni is fogjuk. Nézzük tehát kik és miért mentek el, hogyan és mennyien találták meg a számításaikat Magyarország határain kívül.

\section{Migráns fiatalok európában: kik mennének, mentek el és miért?}

A The Network és Boston Consulting Group, Európa egyik piacvezető állásportálokat tömörítő szervezete 189 országban készített felmérést a migrációs szándékok lehetséges okairól, 200000 fö megkérdezésével, 2014-ben. Magyarországon 5000 fö került a mintába. A felmérésből kiderült, hogy Magyarország tekintetében a külföldi munkavállalás lehetőségét a megkérdezettek 58 százaléka választaná, ez Európában a 23. helyet jelenti - holtversenyben a svédekkel. A hollandok és a franciák igen vállalkozó szellemüek, 94 százalékuk dolgozna országhatárokon kívül. Az Európán kívüli országok közül azonban Pakisztán gyakorlatilag „kiürülne”, mert a megkérdezettek 97 százaléka menne - ha lehetne. Magyarországról a nők 57 százaléka, a férfiak 43 százaléka keresne más országban állást, ezen válaszadók 30 százaléka gyermek nélküli. De 25 százalékban mozdulnának azok is, akik gyermeket vinnének magukkal illetve párban indulnának útnak. Ugyanakkor elgondolkodtató, hogy azok, akik a mintából a távozásra voksolnának, csaknem 50 százalékban valamilyen felsőfokú diplomával rendelkezők (főiskola, egyetem, Phd-fokozat) és mindössze 26 százalékuk középfokú végzettségü. A távozni szándékozók 83 százaléka Magyarországról az anyagikat jelölte meg. (Csak összehasonlításként, a hollandok 55 százalékban inkább világot látnának és tapasztalatokat gyüjtenének.) A magyaroknak csak 14 százaléka jelölte meg azt indokként a kiköltözésre voksolók közül, hogy már van kint rokon, vagy barát. A legtöbben, 23 százalék Londonba, 13 százalék Münchenbe, 10 százalék Berlinbe menne. Az adatokat összehasonlítva azok körében végzett felméréssel, akik már elmentek Magyarországról, nincs lényeges különbség, 51 százalékban nők - többségében egyedülálló -, illetve igen magas az egyedülálló anyák száma (37 százalék), 49 százalékban férfiak mentek el, közöttük jóval több, 50 százalékuk rendelkezik felsőfokú végzettséggel (29 százalék egyetem - benne a Phd-sok; 26 százalék föiskolai diplomával) rendelkezik. Vagyis a végzettség jelentősen befolyásolja az elindulást. Fontos megemlítenünk, hogy egy 2014-es, a MTA Társadalomtudományi Kutatóközpont Kisebbségkutató Intézete által London és környékén élő migráns magyarok körében készített, 5200 mintán végzett online kérdőíves kutatás eredménye szerint is az látszik megalapozottnak, hogy téves az a nézet, amely szerint az alacsony végzettségüek mentek „szerencsét próbálni, takarítani” Angliába. A válaszadók 53, 2 százaléka ugyanis felsőfokú, vagy posztgraduális végzettségü. Átlag életkoruk 33 év (25-40 év közöttiek). Vagyis az igaz, hogy a munka szempontjából legterhelhetőbb, fiatal pályakezdő vagy már tapasztalt diplomások mentek el, tömegével. A kivándoroltak csaknem 14 százaléka a munkanélküliség elöl, 70 százalékuk a munkájuk megbecsülését kifejező magasabb bér és 
jobb életszínvonal reményében. A megkérdezettek háromnegyede, több mint 70 százalék így hát soha nem térne vissza - a megadott válaszok szerint, de legalábbis a következő öt évben biztosan nem, 20 százalékuk néhány év múlva esetleg, s mindössze 6 százalékuk nyilatkozott úgy, hogy egy éven beül, hazatérne.

Visszatérve az NBC Group adatfelvételére lényeges, hogy célországok szerint Magyarországról a választott országok sorrendje Németország, Svájc és Ausztria, az Egyesült Államok, s csak ezek után következik az Egyesült Királyság. A külföldön élő magyarok közül azonban nem mindegyikük van állásban (egyharmad hozzátartozó, vagy épp állást keres a felmérés szerint), 6 százalékuk vezet valamilyen vállalkozást és 55 százalékuk alkalmazott. (lásd: 1. ábra)

1. ábra: Külföldön élö magyarok foglalkozás szerinti megoszlása (forrás: NBC Group adatfelvétel 2014, saját ábra)

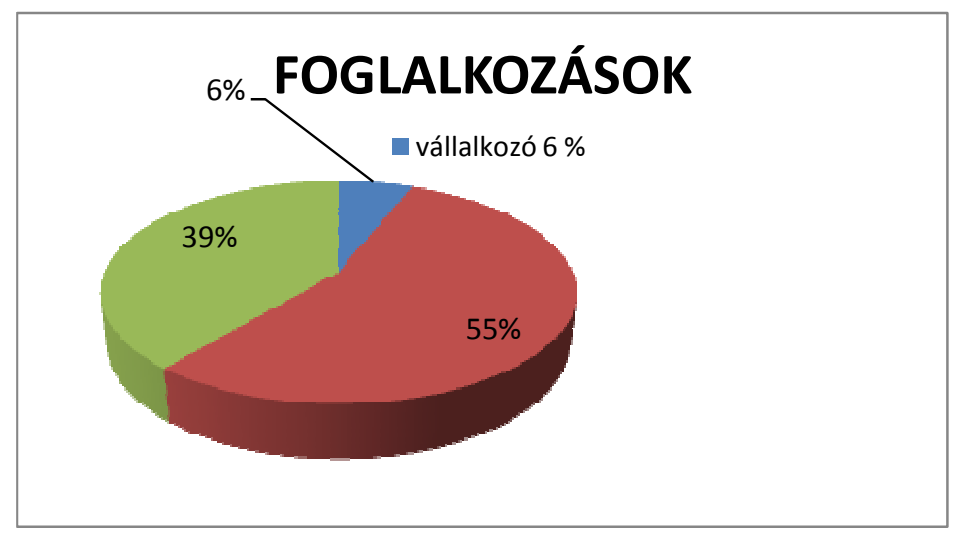

A legtöbben az iparban vagy a technológiában, médiában, telekom-cégeknél állnak alkalmazásban (32 százalék), de sokan dolgoznak a szolgáltatói iparágban is (12 százalék) és kevesebben az egészségügyben (7 százalék - lásd: 2. ábra).

2. ábra: A külföldön alkalmazásban álló magyarok elhelyezkedése - ágazati szektorok szerint (forrás: NBC Group adatfelvétel 2014, saját ábra)
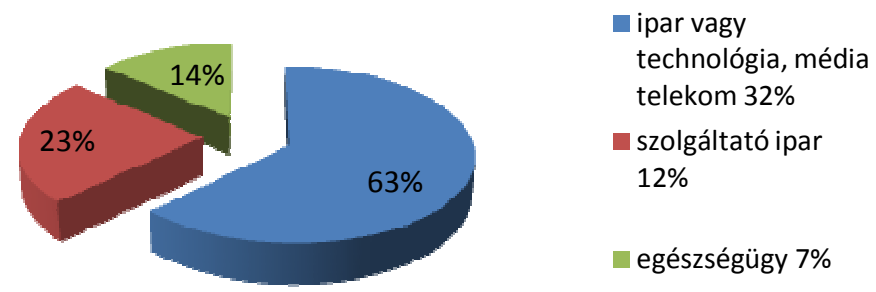
A legtöbben szakmunkásként dolgoznak (közel 30 százalék), a többiek irodai munkát (22 százalék) vagy kétkezi munkát látnak el (15 százalék), illetve alsó vezetői munkakörben vannak. Körülbelül 5 százalékuk helyezkedik el a presztízs piramis csúcsán, mint felső vezető - a felmérés adatai szerint (lásd: 3. ábra).

3. ábra: A külföldön élö magyarok különbözö munkakörei (forrás: NBC Group adatfelvétel 2014 (saját ábra)

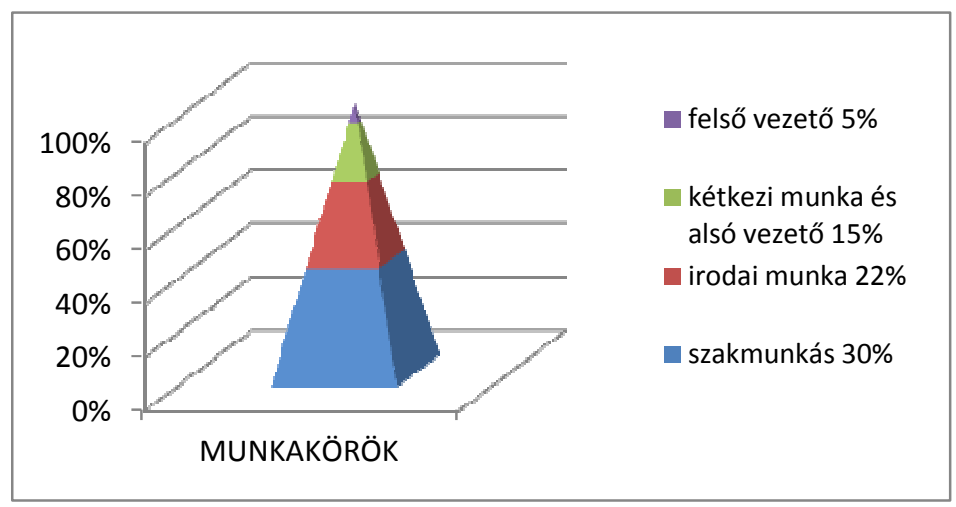

\section{Itthonról másképp látszik}

Annak tükrében, hogy mindkét csoport a már külföldön munkát vállalók és az elmenni szándékozók között is magasabb a nők aránya, mint a férfiaké, nem fedi egy másik, Magyarországon végzett kutatás eredményét. A Magyar Ifjúság 2012 tanulmánykötet szerzöinek felmérése szerint ugyanis, amely kutatás 8000 fös mintán kérdezte meg a 15-29 éves korú magyar fiatalokat, a nők kisebb arányban voksolnak a kiköltözés mellett, mint a férfiak. Különbség van a diplomás és szakképzett fiatalok migrációs hajlandóságában is. A tanulmánykötet szerint utóbbiak inkább kipróbálnák magukat külföldön, miközben a fenti számok azt mutatják, hogy a diplomások jóval nagyobb arányban hagyták és hagynák el az országot, mint a szakmával, középfokú végzettséggel rendelkezők. Itthonról úgy látszik, hogy a diplomások esetén, az „inkább itthon boldogulnék” effektushoz hozzájárul a nem feltétlen megfelelő nyelvtudás, ami nélkül a diplomával kompatibilis - fehér galléros - állás megszerzése nehézségekbe ütközik. Az ifjúsági kutatás - de a 2014-es Eurostat-vizsgálat is azt az eredményt hozta, hogy szignifikáns kapcsolat mutatható ki az idegennyelvtudás és a mobilitási, migrációs hajlandóság között. Az idegen nyelvet nem beszélők 45 százaléka nem tervezi a külföldi munkavállalást, 40 százaléka vállalná az elindulást. Míg a korábban külföldön tanultak populációjából 71 százalék menne, ha lehetősége lenne rá, a külföldet megjárt hallgatók nagyobb hajlandósággal képzelik el a jövőjüket külföldi munkahelyeken. Erre utalt egyébként „A hallgatói mobilitás esete a Bolognai folyamattal" címü tanulmányában Ulrich Teichler is. Eltérő a migrációs hajlandóság azonban az ország különböző területein a fiatalok körében. Régiós összehasonlításban a közép-magyarországi régiót leszámítva - ahol a jobb lehetőségek miatt kisebb mértékben terveznek külföldre menni a fiatalok $(36 \%)$-, országosan gyakorlatilag jóval 40 százalék fölött mennének ugyanakkor, sőt egyes keleti területeken 50 százalék fölötti az arány, fejlettségtől, településtől függően. De befolyásoló tényező a gazdaságilag aktív/passzív térségek helyzetén kívül a család vagy az egyén anyagi helyzete, illetve a családban levő kiskorú gyermekek száma (több gyerekkel kevésbé indulnának el - Ruff, 2013). S míg a 15-19 éveseket visszatartaná az információhiány, addig a felsőoktatásba járók esetén ez a helyzet nem releváns, így számukra 
a visszatartó erő inkább a családi, baráti kapcsolatok erőssége. A Magyar Ifjúság 2012 tanulmánykötet adatai szerint a Magyarországról kivándorló migránsok Németországba, Ausztriába és Nagy-Britanniába mennek nagyobb arányban, ez egybecseng a fent említett NBC Group által készített felmérés adataival, de gyakorlatilag szinte az összes ország célállomás, ahol a gazdasági „gravitáció” elve müködni látszik. Legnagyobb mértékben a 2534, illetve a 34-44 éves korosztály indult el az elmúlt években Nyugat-Európába. Azonban az empirikus adatok szerint Angliában a kifejezetten fiatalabb korosztály (25-29) próbált szerencsét, míg az akár 40, sőt, 50 fölöttiek nagyobb számban Németországban is megtalálhatóak (Ruff, 2013). Mindenesetre tény, hogy az aktív korúak nagyszámú (becslések szerint többszázezres) kivándorlása az elmúlt években nemcsak demográfiailag okoz majd gondot, ahogy már említettük, hanem hosszú távon gazdaságilag is.

A mobilitási attitüdök vizsgálatának elemzését olvasva két jelenség tünik fel, (1) a megkérdezettek több mint fele elhagyná Magyarországot (53\%), ami nagyon jelentős szám, s a fent említett vizsgálat is hasonló eredményt mutatott, (2) a fiatalok 12 százaléka bizonytalan abban, hogy mennyi időre is lenne érdemes külföldre távozni, rövidebben, évekre, vagy végleg. Ugyanakkor tendenciaszerüen látszik, hogy az életkor elörehaladtával egyre kevésbé vonzó a külföldi munkavállalás, míg a 15-19 évesek 55 százaléka menne, addig a 25-29 éveseknél ez az arány 44 százalék (Ruff, 2013). Hiszen nem mindegy, hogy karrierépítés vagy „menekülés” áll a külföldi munkavállalás hátterében. A mintában szereplők közül a rendezettebb családi háttérrel (stabil partner, megfelelő körülmények) kevésbé lennének hajlandóak elmenni, mint a rendezetlenebb háttérrel rendelkezők (pl. gyermektelen elváltak, egyedülállók) (Ruff, 2013). Ez az eredmény is egybecseng, ahogy láttuk fentebb, a már külföldre távozottak körében mért eredménnyel.

Az a fenti adatokból egyértelmüen kitünik, hogy a fiatalok számára a külföldi munkavállalás legföbb oka a jobb megélhetés, amely a szaktudással, ám leginkább a diplomával rendelkező, főként női munkavállalókat szívja el Magyarországról.

\section{Kutatás közben}

A tanulmány utolsó fejezetében folyamatban lévő kutatásunk első részeredményeit kívánjuk bemutatni. Vizsgálatunk a 22-35 év közötti diplomás fiatalokra, elsősorban nőkre terjed ki. Hipotézisünk szerint a fenti kutatásokban szereplő anyagi előnyök mellett a fiatalok elvándorlását azok a külsö-belsö tényezök is motiválják, amelyek miatt e tehetséges (a mintában szereplö), nyitott gondolkodású és lelkületü fiatalok úgy érzik, nem nyílnak meg az általuk elvárt mértékben a kapuk Magyarországon. Sem a munkaerőpiacon, sem a korosztály életfeladatai szempontjából fontos állomásainak szükségszerü megvalósításában - értve ez alatt a megfelelő, motiváló első munkahely megszerzését; az előrelépési lehetőségeket; a külső-belső stabilitás megélését a későbbi otthonteremtésre, családalapításra. S közrejátszik ebben a negatívnak, vagy inkább keserünek nevezhetö érzésben az a „tünet”, amelyet úgy fogalmazhatnánk meg, hogy: a fiatalok által a családból hozott elsödleges értékek (viselkedési szabályok, törvények betartása, tisztelet) devalválódása, a családon kívüli, elsösorban munkahelyi, másodsorban lazább kapcsolati hálózati körben tapasztalt viselkedési és értékpreferencia deficit miatt. Az elkészült interjúk tükrében úgy is fogalmazhatunk, hogy a megrekedtnek tünő gazdasági és közösségi viszonyok azok, amelyek miatt a fiatal korosztály, többségük egy vagy akár két diplomával a zsebében elindul, hogy olyan helyen használja fel az erejét, a tudását és a tehetségét, ahol a megbecsülést is lehetősége lehet megkapni a befektetett energiákért - hangsúlyozottan nem pusztán anyagi szempontból. Így ha nehezebbnek is tünik egy lényegesen nagyobb piacon megméretni magukat, valóságosabb esélyt látnak arra, hogy a kemény munkának (tanulásnak, a beilleszkedési kényelmetlenségeknek, a heti 50-60 órás effektív munkavégzésnek) meglehet a valódi gyümölcse, mert 
általuk preferált - vagy elfogadható, müködő játékszabályokhoz kell alkalmazkodniuk. Nem kell szembenézniük az amúgy is kiszámíthatatlan gazdasági folyamatok diktálta munkaerőpiac mellett egyéb váratlan, tölük független folyamtokkal, amelyek szintén hatással lennének az életritmusuk szerint betölteni kívánt feladatok teljesítésére. S mint a mintánkból hamarosan látni fogjuk, az a döntés, hogy az életfeladat-szerüen tanulással, felsőoktatási tanulmányokkal töltött idő alatt elmegy-e a húszas évei elején járó fiatal huzamosabb időre külföldre - a későbbi európai munkavállalás reményében nem minden esetben korrelál a stabil (szülői) anyagi háttér jelenlétével. Sokkal inkább összefügg az egyén felelősségtudatával, a célok elérésébe vetett hit fiatalos, még akadályokat nem ismerő - vagy épp már megszokott - motiváló erejével, a kitartással, a kreativitással, valamint azokkal a kognitív képességekkel, amelyek miatt az egyén bármely tanulmányi környezetben a kiválóak között lehet.

\section{A célcsoport mintavétele}

E tanulmány elkészítéséig 28 olyan, Magyarországon felnőtt, 18 éves koráig itthon élö, 22 35 éves, diplomás (Bsc, Msc) fiatallal készítettünk félig strukturált interjúkat, akik már évek óta külföldön élnek és dolgoznak, vagy épp állásváltás, kismama-státusz közben vannak, de mindenképpen abban az országban, ahol jelenleg élnek. A statisztika - ahogy fentebb írtuk is - általában a fiatal korosztályt 29 éves kornál lezárja. Azonban úgy véltük, figyelembe kell venni az általunk vizsgálni kívánt korosztálynál azokat a tényezőket, amelyek már egy jó ideje formálják a gondolkodást ezen a téren. Így a későbbre tolódott családalapítási tendenciák, a későbbi házasságkötési és gyermekvállalási kedv (Utasi, 2012), amely szerte Európára jellemző, valamint a fiatalok hosszabb útkeresési időszaka, amelyhez hozzájárul a növekvő fiatal munkanélküliek száma - mint fentebb már jeleztük a diplomásoké is Magyarországon.

Az eddig elkészült interjúk hólabda technika segítségével, szakértöi mintavétellel jöhettek létre, az ország bármely pontjáról elszármazott fiatalokat tekintve. Bár kutatásunk kezdetén többirányú próbálkozásokat tettünk azért, hogy ismeretlenül a facebook, mint modern technikai eszköz segítségével teremtsünk kapcsolatot például Londonban és környékén élö magyar fiatalokkal, a technika először nem akart beindulni. Erős volt a bizalmatlanság. Másnak tünt ugyanis egy személytelen kérdöív kitöltése - erre vállalkoztak volna leginkább, többen is - és más beszélgetni, véleményt mondani, személyes történeteket mesélni - úgy is, hogy közben garanciaként jelöltük meg a válaszadók anonymitását. Ennek a láncolatnak az elindítása végül szintén ismerősök - egyetemi közegből elindult csatornákon keresztül sikerült. Így a referenciák oda-vissza müködésével szépen lassan, estéröl estére megnyíltak a kapuk és ugyancsak a modern technika segítségével létrejöhettek az eddigi skype-interjúk. A technika a multinacionális cégek globális világában nem ismeretlen, a fiatalok hozzászokhattak a skype-on keresztüli HR-interjúkhoz egy-egy állás pályázatával összefüggésben, de alkalmazzák már nyelviskolák is, nem interjúkészítés, hanem oktatás céljából. A hang rögzítését, a szöveg szószerinti leirata miatt skype - recorder program használatával oldottuk meg. Megfigyeltük továbbá, hogy bár a hólabda-technika és a baráti kapcsolatok segítségével országokat és több ezer kilométereket ugrottunk át estéröl estére, vagy épp estéről reggelre, hiszen egyik nap Berlinben, másik nap Provance-ban, majd Svájcban, Münchenben vagy Londonban élő fiatallal készítettük a strukturált interjút, a megkeresések tükrében a válaszadási hajlandóság a német nyelvterületen élők körében mérhetően nagyobb volt. Ennek egyik lehetséges okára a későbbiekben igyekszünk részletesen kitérni.

A kutatás során nem kívántuk foglalkozni azonban a Magyarországról az egészségügyi szakmát képviselő kivándorlókkal, egyrészt, mert az ő esetük egy külön halmazt képez és más 
társadalmi gondokat is feszeget. Valamint azért sem, mert az orvosképzés osztatlan képzésben zajlik, így semmiképpen sem adott volna alapot a későbbiekben az alap- és mesterszakokat végzettek összehasonlítására. Kutatásunk során a továbbiakban is az elvándorlási motiváció, valamint az integráció és a jövőbeni kilátások állnak a középpontban. Keressük a válaszokat arra, hogy diplomájuknak megfelelő állásokban helyezkedtek-e el, mennyiben számított bele a külföldi munkavállalási döntésükbe az egyetem alatt az időszakos tanulmányi célú mozgás (Erasmus, Campus Hungary vagy egyéb ösztöndíjak). Ahogy már említettük, a kutatáshoz félig strukturált interjúkkal kívántuk elkészíteni beszélgetéseket. 4 nagy egységből álló kérdéskört állítottunk össze, amelynek első része a demográfiai adatok felvételét tette/teszi lehetővé, a második egység az elindulás előtti családi, kapcsolati hátteret és hálót kívánta feltárni, a harmadik a jelen helyzetet, valamint a beilleszkedés, integráció elemeit és lehetőségeit kívánta nagyító alá venni és végül a jövőbeni tervek kérdéssora zárja a beszélgetést. Menet közben azonban elrejtettünk a kérdéssorok között úgynevezett „lelkiállapotot” feltáró kérdéseket, illetve a kérdéssor legvégén az egyén személyiségére utaló kérdéseket állítottunk össze. Ez utóbbiak azok a válaszok, amelyeket összesítve már e tanulmányban is meg tudjuk rajzolni az eddig megkérdezett fiatalok személyiségjegyeit, azokat, amelyek nagy valószínüséggel közös jellemzőnek tekinthetőek. S feltehetően szerepet játszhatnak abban, hogy ezek a diplomás fiatalok az adott szituációban, a külföldi munkavállalás mellett döntöttek. Az elkészült interjúkat 2015 októberében készítettük és a következő hetekben folyamatosan rögzítjük a várhatóan újabb 20 interjút, amelyekből a későbbi összehasonlítás reményében 10-15 interjú a diplomával nem rendelkező, 35 év alatti fiatalokkal készül - bárhol Európában.

\section{Demográfiai adatok}

Az eddig elkészített 28 interjú válaszadói az ország különböző területeiről indultak útnak. Közel felük a fővárosból, a többiek Bács-Kiskun, Szabolcs-Szatmár-Bereg, Hajdu-Bihar, Borsod, Fejér, Vas illetve Győr-Moson-Sopron megye városaiból, illetve nem ritkán kisebb falvaiból kerültek ki az európai munkaerőpiacra. A célállomásokat tekintve Németország (München, Frankfurt, Berlin és kisebb települések), Hollandia (Hága, Amsterdam, Rotterdam), Svájc (Zürich, Básel) és természetesen Anglia (London, Oxford és kisebb települések), valamint Franciaország kisebb városai adnak jelenleg otthont az általunk megkérdezett, kivándorolt magyar fiataloknak. Fontosnak tartjuk megjegyezni, hogy bár kutatásunk kezdetén úgy véltük, a mintában felülreprezentáltak lesznek a Londonba és környékére költözött fiatalok, mint már fentebb utaltunk is rá, a válaszadási hajlandóság lényegesen nagyobb volt a német nyelvterületen (Németország, Svájc és környékén, Hollandia) élő magyar fiatalok között. Így a mintában szereplők aránya ezekből az országokból a The Network és Boston Consulting Group által készített felméréssel cseng össze, amely - mint korábban említettük - a Magyarországról választott célországok sorrendjében első helyre tette Németországot, Svájcot (és Ausztriát), azután az Egyesült Államokat, s csak ezek után következik a sorban az Egyesült Királyság. E jelenség valódi okát egyelöre csak feltételezzük.

Végzettségüket tekintve a paletta igen diverzifikált. Többen közgazdász, vagy pénzügyi végzettségüek, de beszélgettünk földmérést végző mérnökkel, gépészmérnökkel, biomérnökkel, vegyészmérnökkel, közlekedésmérnökkel, könyvvizsgálóval, szociológussal, pszichológussal, geográfussal, diplomás szociális munkással és nemzetközi kapcsolatok szakértővel. Egy kivételével mindegyikükre jellemző, hogy a szakmájában helyezkedett el, vagyis végzettségének megfelelö munkát végez. Csaknem mind alkalmazott értelmiségiként, néhányan közülük már középvezetői menedzser szinten dolgoznak. Egyharmaduk szeretne további tanulmányokat folytatni, azonban közülük senki sem jönne haza ezért. Mindegyikük 
külföldön szeretné ezeket a további tanulmányokat elkezdeni, akkor is, ha nem egy továbblépéshez szükséges tanfolyamról, hanem a fizetős mesterképzésről van szó, amelynek költségeit magának a fiatalnak kell - adott esetben -állnia.

Kutatásunk szempontjából lényeges, hogy alap- vagy mesterképzés után vállalt-e munkát külföldön a fiatal és az is, hogy hol végezte a felsőoktatási tanulmányait - itthon, vagy esetleg külföldön. Ebből a szempontból három fő kategóriát állítottunk fel. A „külföldön, itthon illetve vegyesen" kategóriákat, s ezeken belül is alkategóriákat, hiszen a Bsc-, Msc-végzettség is megszerezhető bontásban itthon és külföldön. Ez alapján a következőket mondhatjuk: felmérésünk szerint a mintában szereplök valamivel több, mint 20 százaléka itthon végezte az egyetemi alapképzést, majd a végzés után egyből, vagy kis időre rá külföldre távozott. Valamivel kevesebben, de közel 20 százalékos arányban végezték eleve már az alapképzést is külföldön, közülük néhányan elöször hazatérve próbáltak érvényesülni a kint szerzett diplomával, de a vártnál kisebb siker után ismét másik országban kerestek/keresnek épp állást. Több mint 40 százalékuk itthon fejezte be a mesterképzést is, majd rövidebb-hosszabb idö után, családi okokból (a párjuk már kint dolgozott) vagy elhivatottságból (munkahelyi átszervezések) vagy érvényesülési okokból valahol Európában folytatták. A mintából pedig azok aránya, akik itthon végezték az alapszakot és külföldön a mesterszakot, 25 százalék körüli értéket mutat. Ugyanakkor 10 százalék alatti a mindkét képzést már külföldön végzők aránya. A fennmaradó részt azok töltik ki, akik abban a speciális helyzetben vannak, hogy a PhD-végzettségüket szerezték/szerzik éppen valamelyik európai egyetemen. Közöttük van, aki itthon végezte a mesterszakot is és van, aki azt már a választott külföldi egyetemen.

Az itthon a felsőoktatási intézményekben megszerezhető külföldre szóló ösztöndíjakkal kapcsolatban azért tettünk fel kérdéseket, hogy lássuk, a tanulmányok alatt külföldön végzett szemeszterek mennyiben befolyásolják a későbbi döntést a kiköltözéssel kapcsolatban. Mindent összevéve azt mondhatjuk, hogy a mintában szereplö fiatal felnöttek nem mind vettek részt külföldi tanulmányúton - van a mintában olyan fiatal, aki határozottan elutasította mind az öt év alatt, hogy külföldre menjen huzamosabb időre - azonban minden, ösztöndíjjal külföldet megjárt fiatal rövidebb idön (2-3-éven) belül külföldön keresett és kapott állást s él kint a mai napig. Vagyis abból a szempontból, amelyet dolgozatunk elején említettünk, hogy az Egységes Európai Tanulmányi Térség létrehozói szándékuk szerint Európa munkaerőpiacára képeznék a tehetséges fiatalokat, ennyiben igazolódni látszik. Az más kérdés, hogy ténylegesen hány magyar fiatal él például az Erasmus-ösztöndíj pályázati lehetőségével (a statisztikák szerint a magyar hallgatók mindössze 4 százalékáról beszélünk) hiszen ezek az ösztöndíjak többnyire nem elegendők ahhoz, hogy a diák külföldi tanulmányai alatt a teljes költséget fedezzék, ezért támogatói, vagyis általában szülői háttér függvénye, melyik hallgató foglalkozhat egyáltalán a kiutazás gondolatával.

A válaszadók kétharmada úgy nyilatkozott egyébként, hogy több mint 8 órát dolgozik általában, ezért nem túlórapénzt, hanem több szabadnapot vagy bónuszt kapnak év végén, a közeli barátaik jórészt itthon vannak, külföldön inkább a nemzetközi társasággal (munkahely) járnak kikapcsolódni, illetve természetesen a magyarok „mindenütt megtalálják egymást”. Jelenlegi mintánkban a 28 fiatalból mindössze 2 női válaszadónak volt gyermeke egyiküknek két óvodáskorú, ám ezzel együtt ez a válaszadó a rangidős is (35) az összes megkérdezett között.

\section{Családi háttér}

A családi hátteret vizsgálva a mintában szereplők válaszai alapján számunkra feltünően sokan nőttek fel egyszülős családban. A mintában szereplö fiatalok több mint 40 százaléka elvált szülök gyermeke. A 28 válaszadóból 12-en nyilatkoztak úgy, hogy a szülei elváltak. A szülők iskolai végzettségét tekintve mind az apák, mind az anyák valamivel több mint 50 
százalékban egyetemi, főiskolai végzettséggel rendelkeznek - az anyák esetében ez inkább 60 százalék -, ezen csoportba tartozók közül néhányan tudományos fokozatot is szereztek, valamivel több, mint 30 százalékban a szülők szakközépiskolai érettségivel rendelkeznek, a maradék körülbelül 10 százalék érettségi nélküli szakiskolát vagy nyolc általánost végzett. Az apák foglalkozása szerint körülbelül fele-fele arányban alkalmazásban állók vagy vállalkozók, az anyák több mint 50 százalékban alkalmazásban állók, valamivel több, mint 20 százalékuk vállalkozó, a többiek általában otthon vannak. Érdekes volt látni: ebben a kis mintában is átütö jelenség, hogy a fiatalok szülei közül az elvált anyák voltak/vannak rosszabb helyzetben - mint ahogy azt az egyedül maradt nőkkel kapcsolatban a szakirodalom rendszeresen megemlíti (Vukovich, 1999; Farkas, 2008). Ha volt már a családban valaki munka nélkül, akkor a válaszadók az édesanyát említették jóval nagyobb arányban, vagy jelölték meg jelenleg is betegnek, munkaképtelennek, mint aki a külföldön élő gyermeke segítségére szorul. A válaszadók közel 30 százaléka nyilatkozott úgy, hogy rendszeresen vagy alkalmanként küld haza segítségként pénzt a szüleinek (többnyire az édesanyának), illetve segítette a testvére elindulását ugyancsak valamelyik európai országban.

A válaszadók közel fele itthon, a szülökkel nagyobb (120-150 négyzetméter feletti) házban vagy lakásban lakott, s valamivel kevesebb, mint 30 százalékuk élt kisebb lakásban (panel, 50-70 négyzetméter) vagy házban. A válaszadók csaknem 40 százalékára jellemző volt, hogy a család havi nettó jövedelme a magasabb, 400 ezer forint feletti kategóriába esik - ezen családok egy része akár ennek a jövedelemnek a két-háromszorosával is rendelkezik az élettörténetek szerint -, ennek ellenére százalékosan kimutatható különbség mutatkozik azoknál a válaszadóknál, akik e havi jövedelem alapján érzékelt életminőségüket mégsem a legjobbak között élték meg. Ugyanis annak ellenére, hogy sokszor a család jövedelme magasabbnak mondható a magyar viszonyokat tekintve, s a válaszadók kiválónak vagy jónak élték meg az életszínvonalukat a szülökkel töltött időkben - a középiskola és/vagy az egyetem alatti kollégiumi évekkel együtt -, az esetek nagy részében arról számoltak be a fiatalok, hogy mindez nem jelentette a család számára a „nagy lábon élés” lehetőségét. Nem feltétlen mentek luxus utakra, bár természetesen utaztak, színházba, moziba jártak együtt, rendszeresen. Ezt, a „beosztónak” is nevezhető szemléletet sokan viszik tovább a válaszadó fiatalok közül, az általuk most már megteremetett, s mindenképpen preferált életszínvonal ellenére. Pénzkezelési szokásaik is nagyban változtak, amióta egyedül, de legalábbis a szülőktől távol élnek. Ennek egyik okaként vetjük fel, hogy ezen jó körülmények között felnőtt válaszadók csaknem 20 százaléka nagycsaládban nevelkedett, a testvérek száma 2-3 vagy 4 fö. Jobban ábrázoljuk a helyzetet, ha idézzük a 11. számú (fiú) válaszadónkat, aki, bár fizetős, magán felsőoktatási intézménybe járt, elmondása szerint ettől a család életét nem jellemezte a felesleges költés, hiszen rajta kívül még három lánytestvér volt otthon: „...én 18 -20 éves koromig rendszeresen a Tescóból öltözködtem.”

Ugyanakkor a teljes minta valamivel több, mint 30 százaléka nyilatkozott úgy, hogy a család jövedelme 100 ezer alatt vagy éppen fölötte volt (100-200 között) havonta, közülük mégis nagyobb arányban jó vagy megfelelő színvonalúnak élték meg a szülőkkel közös $s$ az itthon tanulással töltött éveket. Ezt az életutak alapján azzal magyarázzuk, hogy többnyire ezek a válaszadók Magyarországon is a kisebb településeken élö, összetartó, de szolid körülmények kötött levő családokból indultak el. A középiskolai vagy felsőoktatási éveik alatt a kisvárosi kollégiumi élet nem támasztott a megszokottnál magasabb igényeket, ugyanakkor koncentráltan hangsúlyt helyezett a fiatalok tanulmányi előmenetelére. Valamivel több, mint 10 százaléka viszont kifejezetten hangsúlyozta, hogy nem élt jó színvonalon, a családi körülmények nehezítették az életkezdésben és a tanulási lehetőségeiben. 


\section{Néhány ok a külföldi munkavállalásra}

Az elindulás okairól igencsak diverzifikáltak a vélemények, ha az egyéni életutakon keresztül alaposabban szemügyre vesszük a fentebb általunk idézett kutatások ,anyagi okokként" megjelölt, statisztikai terminusait. Mivel a kutatásnak ebben a részében csak részeredményeket tudunk publikálni, így egyelöre ehhez mérten dolgoztuk fel a válaszokban megtalálható okokat:

„Lássuk be, Magyarországon (..) önállósodni sem olyan természetes.” (1 sz. válaszadó - fiú) Nos, e mondatnál plasztikusabban mi magunk sem tudjuk leírni a fiatalok életérzését. Azonban általánosságban azt mondhatjuk, hogy-egy-két „hirtelen ötlettől” vezérelt lépéstől eltekintve - épp az idézett mondat miatt - a mintában szereplö fiatalok egy része vagy tudatosan, az egyetemi tanulmányokat jól felépítetten (itthoni alap-, külföldi mesterképzés, vagy már kint is kezdett), vagy a menet közben megszerzett információk hatására lépett átgondoltan. Ahogy $2 \mathrm{sz}$. válaszadónk (fiú) is fogalmazott: „...az Egon Biztosítónál találtam állást Amszterdamban. Kockázatkezelöként dolgoztam ott. Felvettek, mert megvolt ugyanaz a mester diplomám, mint a helyieknek."

Nos, a többi között ezért is fontos a kutatásban tisztáznunk az itthon, illetve külföldön végzett alap- és mesterképzések arányát. Az eddigi mintában szereplő fiatalok válaszai alapján ugyanis azt mondhatjuk, hogy akik valamelyik - vagy mindkét - diplomájukat már külföldön kapták vagy viszonylag hamar elmennek, vagy vissza sem jönnek. Hiszen azzal, hogy valahol Európában végzik például a mesterképzésüket, lényegesen könnyebb versenybe szállni ugyanazért az állásért.

Ám természetesen van még egy érv, a külföldi munkavállalás mellett, amelyet nem szívesen hagynánk ki a sorból - bár ismét hangsúlyozzuk, hogy a lista még korántsem teljes. Nevezetesen, a hazai diplomás fiatalokat sújtó munkanélküliség, mint az életkezdési esélyeket akadályozó tényező. S bár területfüggő, hogy Magyarországon hol találnak könnyebben állást a fiatalok a végzés után a saját szakmájukban, a gazdaságilag nehéz körzetekben élök esetén kitartó keresgélés után is gyakran két lehetőség adódik: vagy a szakma feladása, vagy persze a megyehatárok, sőt: az országhatár átlépése tünik a legkézenfekvőbb megoldásnak.

\section{A fiatalok lelkiállapotáról}

Az általunk megkérdezett, a mintában szereplö fiatalok csaknem 100 százaléka - közepesen vagy nagyon, de - elégedett a jelenlegi helyzetével, azzal, ahol az élete éppen tart. A „csaknem” általában valamilyen lelki (párkapcsolati, családalapítási, épp szakítási, állásváltási) gondokkal függ össze, mindössze egy válaszadó nyilatkozott úgy, hogy talán a nem megfelelö alapdiploma az, amely miatt nehezebben talál állást az adott országban. Jóllehet ez, a 24. számú válaszadó egy két éves kisgyermek édesanyja, így körülményei is nehezebbek, mint a többi, 93 százalékban gyermektelen fiatalnak. Azonban meglepö, hogy azok a válaszadók is elégedettségnek adtak hangot a jelenlegi helyzetükre vonatkozóan, akiknek itthon, Budapesten saját lakásuk volt, most pedig évek óta albérletet fizetnek a célországban. A mintában szereplök kétharmada kifejezetten sikeresnek ítélte meg az eddigi szakmai életútját - ahhoz képest, mint amit itthon sikerült volna elérniük - nemcsak anyagi téren. A személyiségükkel kapcsolatos válaszokból nominálisan is egyértelmüen kiderül, hogy döntő többségük optimista alkatnak, inkább extrovertált személynek és érzelmileg stabilnak tartja magát, ezen jegyek negatív - komplementer párjait csak néhányan említették. Fele-fele arányban jól, illetve kevésbé jól türik a stresszt, viszont feltűnő, hogy szinte egyformán határozottan állították - kevés kivételtől eltekintve -, hogy szeretnek küzdeni. Mindemellett a függetlenség érzésére egy ötös skálán négyesnél rosszabbat senki sem adott magának. 18-an az 5-ös, 10-en a 4-es mellé tették le a voksukat. S bár a „független” szó 
jelentését a kérdésben nem szükítettük le, az tendenciózusan megfigyelhető, hogy akik 4-est adtak maguknak, azon válaszadók vagy párban élnek jelenleg, vagy nagyon afelé fordult a gondolkodásuk, hogy mihamarabb stabil partnert találjanak maguknak.

\section{Jövedelmi viszonyok - terhek spiráljában}

Az alapdiplomával rendelkező fiatalok, kisebb vagy nagyobb cégeknél, adminisztratív vagy terepmunkát kívánó állásokban, illetve a szociális szférában dolgozók euróban számolva 1500 és 1800 euró közötti fizetésekből élnek - általában párkapcsolat nélkül, többnyire egy szobát bérelve. Külön kategóriát képeznek azonban azok a pénzügyi végzettséggel rendelkezö, általában már mesterdiplomás fiatalok, akik a húszas éveik vége felé, illetve a harmincas éveik elején járnak a mintában, többségük az alapdiplomát itthon szerezte, a mestert már valahol Európában, majd valamelyik nagy - multinacionális - vállalatnál helyezkedtek el. Ezen fiatalok ugyanis - az adott országban szerzett végzettségüknél fogva - mindenképpen a multi környezetnek megfelelő éves fizetést kapják, legyen szó Berlinről, Londonról, Hágáról, Amszterdamról vagy Zürichről. Körükben az évi 50-80 ezer fonttól a 90-120 ezer euróig terjed a jövedelmük. Ök már nem szobát, hanem 2-3 szobás apartmanokat bérelnek, e világvárosok legjobb helyein. Legtöbbjük nem több mint 3-4, esetleg 5 éve ment el Magyarországról (pénzügyi területen a mesterképzés sok helyütt nem kettő, hanem egy erős év).

Azonban éppen azért készítettünk egyéni életút-interjúkat, hogy meglássuk az ide vezető utakban rejlő különbségeket és azonosságokat. Nem állíthatjuk, hogy annak a fiatalnak nem volt könnyebb külföldön végeznie a mesterképzést, akinek a szülei átlag havi 1000-1500 euróval (mert ennyit említettek a fiatalok) hozzájárultak a költségeihez, mint aki az addigi munkáiból tudatosan félretett pénzéből, diákhitelből fedezte a tanulmányait. $\mathrm{S}$ amely hitelt természetesen euróban vett fel - mint konkrét példánk is mutatja - ezek a diákhitelek nem kevesek (35 000 euró például egy spanyolországi egyetem mesterképzése). Európának ezen a részén a felsőoktatási intézmények „nem feltétlen engedik meg maguknak”, hogy addig hitelezzenek a volt diáknak, amíg az megfelelö jövedelemre szert nem tesz ahhoz, hogy a megélhetését ne befolyásolja a részletfizetés. Anglia más gyakorlatot követ - mint erre korábban már utaltunk. S mint 20. számú válaszadónktól megtudtuk, ehhez a diákhitelhez hogy ez „csak ennyi” - maximálisan kellett teljesítenie. Az angol nyelven zajló oktatás minden egyes tárgyában (pénzügy) kiváló minősítéseket kellett szereznie. Úgy vette fel a hitelt, hogy közben kiszámolta, ha végez, mennyi pénzt kell ahhoz keresnie havonta, hogy lakást béreljen valahol, törlesszen, éljen, havi rendszerességgel küldjön haza támogatást a Szabolcsban egyedül élő édesanyjának, néha haza is tudjon jönni, meglátogatni öt is és elvált szülők gyermekeként - a fővárosban élő édesapját és a testvéreit is. Hogy ezt elérje, 20. számú válaszadónk saját bevallása szerint vagy 200 céghez adta be az önéletrajzát a végzéshez közeledve. Ebből 10 megvalósult állásinterjún vett részt, végül három ajánlatból került el Londonba, egy hitelminősítő világcég egyetlen pozíciójába. 20. számú válaszadónk mindehhez 26. életévét tölti. Ilyen körülmények között fel sem vetődhetett, hogy itthon keres állást a diploma után. Teljesen egyértelmü, hogy ezeket a terheket egyetlen, Magyarországon esetlegesen kapott szerződéssel - jövedelemmel - sem tudta volna teljesíteni.

Megfigyeléseink szerint egyébként mindkét csoportra jellemző volt, akár a szülők által támogatottan, akár saját maga által megoldott finanszírozással végezte is el a fiatal külföldön a mesterszakot, hogy kitartóan, az összes megszerezhető képesség birtokában tanultak, tanulnak és dolgoznak. Illetve kevés kivételtől eltekintve általánosságban jellemzően mondhatjuk a mintára, hogy már az alapképzés alatt szinte végig dolgoztak. A szülöi támogatást egyáltalán nem élvező fiatalok - ilyen a minta közel 30 százaléka - a tanulmányi idő alatt is folyamatosan vállalt munkát, annak ellenére, hogy nappali képzésben végezték az 
egyetemet. Illetve természetesen az oktatási szünetekben - itthon és külföldön egyaránt Magyarországon ez diák- vagy alkalmi munkákat jelentett számukra. Ezek az alkalmi munkák - a fiúk esetében - semmiképpen nem kizárólag „fehérgalléros” munkalehetőségeket hozott. Igen kreatívan, a lakóhelyükhöz közeli, például konzervgyári rakodástól a 24 órás éjjelnappali készenlétet kívánó fordítói munkáig, igen széles palettát vonultattak fel a fiatalok a válaszaikban. Fontos megjegyeznünk, hogy egyik válaszadó sem említette, hogy a szülei ösztönzésére vállalta volna a kemény munkákat, vagy egyáltalán a munkákat a szünidőben, vagy az iskola alatt. Mindegyik diák maga szeretette volna megragadni a lehetőséget, vagy azért, mert szüksége volt a zsebpénzre, vagy azért, mert a kitüzött céljaihoz igyekezett a referenciákat gyüjteni. A külföldön a tanulmányok alatt dolgozó fiatal nők általában nagyobb cégek gyakornokaiként dolgoztak, viszonylag kis jövedelemért (800-1000 euró), amelyekböl épphogy csak ki tudtak jönni hó végére. Némelyikük azért hagyott ki időt az alap- és a mesterdiploma között, hogy össze tudja gyüjteni a mestertanulmányok idejére szükséges önellátás feltételeit, mert egy erős, nappali mesterképzés mellett viszont egyáltalán nincs mód munkát vállalni. Legalábbis nem éri meg másra figyelni, mint a tanulásra. Ami viszont egységesen leszürhető ebböl a hozzáállásból: ezek a diákok, akik külföldön is jó állásokban állják meg a helyüket, hozzászoktak a teljesítményorientált gondolkodásmódhoz, nem idegen tölük a kitartást igénylö munka.

Azt is elmondhatjuk a minta alapján, hogy a megkérdezettek itthon, Magyarországon átlag 40-60 ezer forintból gazdálkodtak havonta az alapképzésük idején, vagy kollégiumban, vagy többen szobát bérelve, igen ritkán otthon lakva. Azok is ezt a 60 ezer forintos havi zsebpénzt említették, akiknek esetleg - a családi helyzettől függően - saját lakásuk volt már az egyetem ideje alatt. Ezek a fiatalok - többnyire nők - ugyanis ilyen esetben kiadták a saját lakásuk egyik szobáját vagy „sarkát” egy másik diáktársuknak, így nem egyedül osztoztak a terheken. Ezt tették egyébként azok az extrém helyzetben lévő fiatalok is, ahol a szülö (szülők) korai elhalálozása, illetve a család szétesése miatt egyedül tartották el magukat a fiatal lányok/nők, gyakorlatilag 14-16 éves koruk óta (a havi árvasági segély járt). Ezért ezeknek a fiataloknak létkérdés volt, hogy az egyetem alatt rendszeresen dolgoznak, azonban ezen diákok extrém teljesítményt is képesek voltak nyújtani az egyetemen ahhoz, hogy a maximális ösztöndíj és számos más, pályázat útján megszerezhető jövedelmük legyen.

Ilyen kitartó szorgalom és nehéz családi viszonyok után talán nem is csoda, hogy szüknek bizonyultak a lehetőségek itthon és elindultak - történetesen már közgazda alap-/mesterdiplomával a zsebükben - Európába.

A státuszszerzési helyzeteket illetően a válaszadók körülbelül 85 százaléka válaszolta azt, hogy lényegesen jobb a helyzete, mintha itthon élne, dolgozna, és akarna továbblépni. A kinti jövedelemből általában albérletre, az életre, utazásra és némi megtakarításra is jut, bár ez terhektöl és igényektől függően természetesen változó.

A jelenlegi válaszadók közül körülbelül 15 százalék az, akinek a státusza nem jobb, inkább egyenlö azzal, mintha itthon maradt volna - különösen a pénzügyi területen elhelyezkedök nyilatkoztak úgy, hogy itthon is jóval az átlag fölött lenne a fizetésük. Azonban mindegyikük jobban érzi magát, mintha Magyarországon lenne hasonló helyzetben, ennek okaként a munkahelyi környezetet és az emberek közötti viselkedési szabályok tiszteletben tartását, az egymáshoz való hozzáállást említették, amelyet a jelenlegi helyzetükben lényegesen elfogadhatóbbnak tartanak, összehasonlítva az itthon szerzett esetleges munkatapasztalatokkal, élményekkel. Az életminőségükhöz viszont - saját bevallásuk szerint - kifejezetten hozzájárulnak a kinti kapcsolati és munkahelyi élmények, amelyekről a minta több mint egyharmadának volt már itthon negatív tapasztalata. 


\section{Konklúzió}

A társadalmi mobilitás kutatás egyik klasszikusára, Sorokinra hivatkozva, Róbert Péter a demokratikus társadalmak teoretikus szabályai szerint müködő nyitott társadalomról szólva azt írja, hogy az egyén társadalmi pozícióját nem a születés határozza meg, hanem a nyitott pozíciókkal kecsegtető lehetőségek, hiszen az egyén szabadsága és függetlensége, mint legfőbb érték jelenik meg, és a megengedő szemlélet szerint „mindenki azzá válhat, amivé a képességei teszik" (laissez-faire). A társadalmi mobilitás értéke és értelme funkcionalista alapok szerint viszont megközelíthető úgy is, hogy a gyermekek különböző státuszú (foglalkozás, iskolázottság, vagyoni helyzet) családokba születnek bele, miközben - ettöl függetlenül - a tehetségek és képességek feltehetően egyenletes eloszlást mutatnak egy társadalmon belül. A mobilitás tehát mintegy „korrigálja” a származási különbségeket azzal, hogy különböző szürők segítségével mindenki arra a helyre kerül, ahol a társadalom számára a leghasznosabb. Fentebb hosszan leírt saját, folyamatban lévő kutatásunk részeredményei és az említett statisztikákat összegző vizsgálatok tükrében joggal tehetjük fel a kérdést - vajon melyik társadalom hasznára lesznek éppen a külföldre távozott diplomás fiatalok, akiknek jelentős része egyedülálló nő? $\mathrm{S}$ ha az egyetemisták nagy többségére igaz is az a Hrubos-féle megállapítás, hogy az alap- és mesterképzés lépcsője szürőhatásként érvényesül, különösen a fizetős szakok bevezetése óta, a kis mintánkban szereplő életutak mégis azt bizonyítják, a tehetséges kivételek mégsem a szürőhatás íratlan szabályát erősítik. Saját kutatásunk eddigi eredményei alapján általánosságban elmondhatjuk, hogy azok a diákok, akik külföldön is jó állásokban állják meg a helyüket, hozzászoktak a teljesítményorientált gondolkodásmódhoz, felelősségtudatuk igen fejlett az itthon maradt, esetlegesen rászoruló családtagok támogatását illetően, vagy/illetve az őket a tanulásuk alatt jelentős mértékben támogató szülők felé. A minta közel kilencven százalékában erős a kötődés az itthoni családtagokhoz, ez a gyakori, általában heti egy-két - nem ritkán napi - kapcsolattartási szokásokból könnyen leszürhető. Ugyanakkor nyitottságuk, nagy többségében optimista szemléletük és saját bevallásuk szerint nagyobb számban extrovertált személyiségük, minden feladatot megoldani vágyó küzdési hajlamuk alkalmassá teszi öket arra, hogy ne csak Magyarország kisebb, ám szükebb munkaeröpiacán, hanem a nagyobb, ám lényegesen több lehetőséget nyújtó európai munkaerőpiacon is sikeresek legyenek. Ennél fogva tehát mintánkban is alig néhány fiatal válaszolta kérdésünkre azt, hogy belátható időn belül - vagy bármikor a jövőben - hazatérne.

\section{Irodalom}

Balogh, L. (2006): A tehetséggondozás pszichológiája Alkalmazott pszichológia. 33-49.

Bodnár, G., Takács, I., Balogh, Á. (2011): Tehetségmenedzsment a felsőoktatásban. Kiadó: Magyar Tehetségsegítő Szervezetek Szövetsége. Letöltés: 2015. október 26. Web: http://tehetseg.hu/sites/default/files/19_kotet_net.pdf\#page=11

Bondzsér, Z.(2012): Kollégiumok szerepe, helye a magyar közoktatás és szakképzés rendszerében Tehetségfejlesztés tehetséggondozás feladatok, lehetöségek.Letöltés: 2015.október 26. Web: http://www.fovpi.hu/data/cms149065/Bondzser_Zita.pdf

Czeizel, E. (2003): Legnagyobb természeti kincsünk: a tehetség Fizikai Szemle 2003/11, Letöltés: 2015. október 26. Web: http://fizikaiszemle.hu/archivum/fsz0311/c zeizel0311.html

Farkas, Sz. (2008): Néhány információ az egyszülős családokról. TÁRKI, Letöltés: 2015. november 1.web: file:///C:/Users/edit/Downloads/farkaszs_egyszulos_csaladok_2008.pdf

Gazsó, T. (2012) Munkaerő - piaci helyzetkép. Magyar Ifjúság. 127-152.

Gábor, K., Szemerszki, M., Tomasz, G.(2006): A kétciklusú képzés kezdetei; FKI; Budapest.

Gömöry, K. (2010): Az iskolai tehetségfejlesztés pszichológiai háttértényezöinek vizsgálata felső tagozatos korban Letöltés: 2015. október 26. Web: https://dea.lib.unideb.hu/dea/ 
bitstream/handle/2437/104992/G\%C3\%B6m\%C3\%B6ry\%20Korn\%C3\%A9lia\%20-\%20\% C3\%A9rtekez\%C3\%A9s-t.pdf?sequence=7\&isAllowed=y

Hrubos, I.(2012): A társadalmi esélyegyenlőtlenségek új színterei a felsőoktatásban. Iskolakultúra, 2012/1-2; Letöltés: 2015. október 30. Web: file:///C:/Users/edit/Downloads/ korrekt\%C3\%BAra.pdf

Róbert, P. (2001): Hipotézisek az oktatás és a társadalmi mobilitás összefüggéseiről. Társadalmi mobilitás,2001, 1 156-164.

Róbert, P. (1990): Társadalmi mobilitás; Társadalmi Riport 1990. Szerk.: Andorka - KolosiVukovich; 356-372.

Ruff, T. (2013): Ifjúsági mobilitás: hajlandóság, lehetőségek és tervek in: Magyar Ifjúság Tanulmánykötet 2012 Letöltés: 2015. október 30. Web:http://kutatopont.hu/files/2013/09/ Magyar_Ifjusag_2012_tanulmanykotet.pdf

Ságvári, B.(2012): Az átmenetek kora?- A magyar fiatalok társadalomképéről, in: Társadalmi integráció a jelenkori Magyarországon, Tanulmányok; MTA Társadalomtudományi Kutatóközpont (Szociológiai Intézet), Argumentum Kiadó; p. 63-82.

Teichler, U.(2011): A hallgatói mobilitás esete a Bolognai folyamattal Letöltés: 2015. október 30. Web: http://epa.oszk.hu/01500/01551/00058/pdf/educatio_EPA01551_201104_tan5.pdf

Utasi, Á.(2002): Társadalmi integráció és családi szolidaritás. Educatio 2002/3 (384-404. pp) Letöltés: 2015. október 31. Web: file:///C:/Users/edit/Downloads/2002_3_ tan_UA\%20(2).pdf

Veroszta, Zs. (2013). Letöltés: 2015.10.10. Web: www.felvi.hu/pub_bin/dload/ frissdiplomasok2011.../veroszta.pptx

Vukovich, G.(1999): Egyedülálló szülők és gyermeküket egyedül nevelő szülők. Letöltés: 2015. november 1. Web: http://www.tarki.hu/adatbank-h/kutjel/html/a615/

\section{Internetes hivatkozások}

Net 1: Tehetséges fiatalok menedzselése a felsőoktatási intézményekben Letöltés: 2015. október 26. Web: http://tehetseg.hu/sites/default/files/19_kotet_net.pdf\#page=11

Net 2: Ponthatárok, statisztikák, rangsorok Letöltés: 2015.október 26. Web: http://www.felvi.hu/felveteli/ponthatarok_rangsorok

Net 3: Decodig global talent Letöltés: 2015.oktober 29. Web:https://www.bcgperspectives. com/content/articles/human_resources_leadership_decoding_global_talent/

Net 4: Miért indulnak útnak a magyarok Letöltés: 2015.oktober 29. Web: http://hataratkelo.blog.hu/2015/10/13/miert_indulnak_utnak_a_magyarok

Net 5: Az ország gerince megy el Letöltés: 2015.oktober 29. Web: http://hataratkelo.blog. hu/2014/06/05/az_orszag_gerince_megy_el 


\section{MÓDSZERTANI TANULMÁNYOK}




\section{A FEJLESZTŐPROGRAMOK HATÁSVIZSGÁLATÁT SZOLGÁLÓ ADATBÁZISOK SZERKEZETE EGY INGYENES STATISZTIKAI SZOFTVERBEN: AZ R-BEN}

\section{Szerző:}

Abari Kálmán

Debreceni Egyetem

Mező Ferenc

Debreceni Egyetem

Mező Katalin

Debreceni Egyetem

Máth János

Debreceni Egyetem

\section{Lektorok:}

Demetrovics János

Eötvös Lóránd Tudományegyetem

Nagy Dénes

Nemzetközi Szimmetria Társaság

Varga Imre

Szegedi Tudományegyetem

Koncz István

Professzorok az Európai Magyarországért

Egyesület

Első szerző e-mail címe:

abari.kalman@arts.unideb.hu

Abari Kálmán, Mező Ferenc, Mező Katalin és Máth János (2015): Fejlesztőprogramok hatásvizsgálatát szolgáló adatbázisok szerkezete egy ingyenes statisztikai szoftverben: az Rben. Különleges Bánásmód, I. évf. 2015/2. szám, 37-47. DOI 10.18458/KB.2015.2.37

\section{Absztrakt}

A (gyógy)pedagógiai fejlesztôprogramok matematikai statisztikai alapokon nyugvó hatásvizsgálatához lényeges: 1) ismerni a minimálisan szükséges matematikai alapfoalmakkal (ezeket lásd: Máth és tsai, 2015), 2) egy megfizethetö áru statisztikai szoftver, 3) e szoftverek alkalmazásához szükséges - legalább felhasználói szintü - jártasság is. E két utóbbi szükségletre nyújt praktikus megoldást jelen tanulmány, miközben bemutatja az $R$ nyelvet, $s$ annak lehetöségeit.Az $R$ egy ingyenesen letölthetö, matematikai statisztikai számítások végrehajtására is alkalmas szoftver, mely praktikus segédeszköze lehet a különleges bánásmódot igénylök kutatásának. Jelen tanulmány az R-röl szóló rövid tájékoztatót követöen a kutatások során keletkezett adatok adatbázissá, adattáblává szervezését foglalja össze a fejlesztöprogramok hatásvizsgálatának három jellegzetes esetében.

Kulcsszavak: fejlesztőprogram, hatásvizsgálat, statisztika

Diszciplinák: matematika, pszichológia, gyógypedagógia, pedagógia

\footnotetext{
Abstract

STRUCTURES OF DATABASES FOR IMPACT STUDIES OF DEVELOPMENT PROGRAMMES IN A FREE STATISTICAL SOFTWARE: IN THE SOFTWARE 'R'

In order to carry out effectiveness study of the development programmes (e.g. education, children with special needs) based on mathematical statistical methods, the follwing factors are important: 1) you need some basic mathematical definitions (Math et all., 2015), 2) a
} 
statistical software (e.g.: the ' $R$ ') at a reasonable price, 3) some experience in working with this software. The ' $R$ ' is a free downloadable software (that can be applied in mathematical statistical calculations too) which can be a very useful instrument of research of children who need special treatment. This paper provides a practical solution in connection with the last two factors, and introduces language ' $R$ ' and its possibilities.

Keywords: development programme, effectivenes study, statitics

Disciplines: mathematics, psychology, special education, pedagogy

A különleges bánásmódot igénylő tanulók számára kidolgozott (gyógy)pedagógiai, pszichológiai fejlesztőprogramok hatásvizsgálata főként különbségvizsgálatok révén valósulhat meg. E különbségvizsgálatok alkalmával:

a) Egymintás különbségvizsgálatról beszélünk, ha egy fejlesztésbe bevont csoport vizsgálati eredményét vetjük egybe a fejlesztési célként kitüzött célértékkel.

b) Összetartozó mintáról beszélünk akkor, ha egy csoport két (pl. fejlesztést megelőző és követő) vagy több alkalommal (pl. több éven keresztül történő nyomon követéses jelleggel) mért vizsgálati eredményeit hasonlítjuk össze.

c) Független mintás vizsgálatról beszélünk akkor, ha két (pl. a fejlesztésbe bevont vizsgálati, $\mathrm{s}$ be nem vont kontrollcsoportot) vagy több (pl. három különbözö olvasástanítási módszerrel fejlesztett) csoport eredményeit hasonlítjuk össze.

E hatásvizsgálatok közül az egymintás és az összetartozó mintás esetek szervezési szempontból egyszerübben megoldhatók, hiszen „csak” a fejlesztésbe bevont tanulókról szükséges adatot gyüjteni, s kontrollcsoport(ok) keresésére, vizsgálatára nincs szükség. Éppen ezért egy fejlesztőprogram hatásvizsgálatával kapcsolatban az egymintás, illetve az összetartozó mintás különbségvizsgálatok matematikai statisztikai alapokon nyugvó elemzése fogalmazható meg olyan minimum követelményként, amely a nem eseti jellegü fejlesztőhatás bizonyításához szükséges (a Magyar Tehetségsegítő Szervezetek Szövetsége által koordinált tehetségpont-hálózatban például az önkontrollos hatásvizsgálatokkal történő bizonyítás igénye jelenik meg - Balogh és Mező, 2010). Természetesen a független mintás vizsgálatok további bizonyítékokkal szolgálnak a programok fejlesztőhatásával kapcsolatban.

Bármely különbségvizsgálatot válasszuk is azonban, a szükséges adatok - például megfigyelés, kísérlet, interjú, tartalomelemzés, kérdőív felvétel, tesztelés révén történő összegyüjtését követően azokat adatbázisba kell rendeznünk, s ezt követően kezdödhet el a matematikai statisztikai szintü adatelemzés. Ugyanakkor: már a vizsgálat(sorozat) tervezésekor célszerü átgondolni a későbbiekben létrejövő adatbázis szerkezetét, s figyelemmel érdemes lenni a matematikai statisztikai számításokhoz alkalmazott szoftvernek az adatbázisokra, adatbázis-szerkezetekre vonatkozó követelményeire.

A fentiek alapján, jelen tanulmány csak az egymintás és az összetartozó mintás hatásvizsgálatokra fókuszál a továbbiakban, s foglalja össze tömören a matematikai statisztikai elemzéshez használható $\mathrm{R}$ szoftverrel kapcsolatos leglényegesebb információkat (független mintás esetekkel kapcsolatban lásd: Mező, Máth és Abari, 2008). E tanulmány feltételezi Máth és tsai (2015) összefoglaló tanulmányában közölt matematikai statisztikai alapfogalmak (pl. változó, skála, eloszlás, populáció, minta, hipotézis vizsgálat, szignifikancia) ismeretét. 


\section{Az R nyelv}

Az R egy magas szintü programozási nyelv és környezet, melynek legfontosabb felhasználása az adatelemzés és az ahhoz kapcsolódó grafikus megjelenítés. Az $\mathrm{R}$ egy szabadon használható, többplatformos (Windows, OS X, Unix és Linux operációs rendszereken futó) programcsomag, amely 1995-ös létrehozása óta egyre közkedveltebb a statisztikai elemzés területén. Népszerüsége nem csupán ingyenességének köszönhető. Az R a statisztika és a programozási nyelvek világából érkező szakemberek nemzetközi együttmüködésének a terméke, így a kínált statisztikai eljárások szinte végtelen, dinamikusan növekedő tárházat egy teljes értékü, objektum-orientált programozási nyelv segítségével érhetjük el. Az R kiváló grafikus képességekkel rendelkezik és rendkívül jól dokumentált. Elsajátítása azonban nagyobb kezdeti befektetést igényel, ugyanis az R-rel való kommunikáció parancsok egymás utáni megadásán alapul.

Az R nyelv egy ún. interpretált szkript nyelv, azaz az utasításainkat nem fordíthatjuk le futtatható állománnyá, hanem a végrehajtandó parancsokat az $\mathrm{R}$ egyesével értelmezi (ellenőrzi a parancs szabályosságát, ha megfelelőnek találja, rögtön végrehajtja). Az $\mathrm{R}$ program legfontosabb része tehát az R-értelmező (interpreter), amely a parancsok végrehajtásáért felelős. Az R-interpreterhez kétféle módon juttathatunk parancsot, vagy interaktívan, az egyes parancsok begépelésével, vagy „kötegelten” ún. szkript módban, előre összegyüjtött parancsok formájában.

Az R hivatalos oldala a http://www.r-project.org, ahol számos információt találunk az Rkörnyezetről, valamint itt találhatjuk meg az operációs rendszerünknek megfelelő telepítőt is. A Windows verzió közvetlenül a http://cran.r-project.org/bin/windows/base oldalról tölthetö le. Itt az R-3.2.2-win.exe linken kattintva tölthetjük le számítógépünkre az R telepítőt, ugyanis jelen tanulmány írásakor a legfrissebb változat a 3.2.2 volt. Ez a hivatkozás folyamatosan változik, mivel évente kb. 2 új $R$ verzió megjelenése várható. A telepítő program futtatásával az R-t számítógépünkre installálhatjuk.

Az $\mathrm{R}$ Windows verziójának indítása után egy rendkívül egyszerü felhasználói felületet kapunk (RGui), amelynek legfontosabb eleme az $R$ Console nevü ablak. A konzolban megjelenö '>' (nagyobb jel) jelzi számunkra, hogy az $\mathrm{R}$ várja a parancsainkat. Ez az ún. prompt, amely után egy tetszőleges karaktersorozat begépelésére van lehetőségünk. A begépelt parancsot az ENTER billentyüvel küldjük el az R értelmezőnek, amely ha mindent „rendben” talál a parancsunkban, akkor végrehajtja azt.

Az alábbiakban a teljesség igénye nélkül összefoglaljuk az $\mathrm{R}$ adatkezelésével kapcsolatos fontosabb függvényeket és operátorokat:

1) Az R-környezet parancsai:

- Objektumok listázása: ls(), objects()

- Objektumok törlése: rm()

- Beépített adatobjektumok kezelése: data()

- Csomag letöltése, telepítése: install.packages()

- Telepített csomag betöltése: library()

- Munkakönyvtár kezelése: getwd(), setwd(), dir()

- Szkript futtatása: source()

- Környezetek kezelése: search(), attach(), detach()

- Segítség kérése: help(), ?, help.search(), help.start(), find(), apropos(), example(), vignette(), demo(), RSiteSearch()

2) Alapmüveletek parancsai:

- Értékadás: $<-,,=,<<-,->,->>$

- Matematikai müveletek: $+,-, *, /, \wedge, * *, \% / \%, \% \%$ 
- Logikai müveletek: ==,!=, <, >, <=, >=, \&, |, !

- Karakteres müveletek: paste(), nchar(), substr()

- Vektor vagy (rendezett) faktor indexelése: $x[4], x[2: 3], x[-2], x[-(3: 5)], x[c(2,4,6)]$, $\mathrm{x}$ ["elemnev"], $\mathrm{x}[\mathrm{x}<5], \mathrm{x}[\mathrm{x}>7$ \& $\mathrm{x}<11]$

- Lista vagy adattábla indexelése: d[3], d[[3]], d\$elemnev

- Mátrix vagy adattábla indexelése: $\mathrm{m}[2,3], \mathrm{m}[, 2], \mathrm{m}[, 3], \mathrm{m}[1: 3,-4], \mathrm{m}[\mathrm{c}(3,2,6), \mathrm{c}(2,4)]$

- Adatobjektum módja és hossza: mode(), length()

3) Adatok beolvasása és kiírása:

- Adattábla beolvasása tagolt szöveges állományból: read.table(), read.csv(), read.csv2(), read.delim(), read.delim2()

- Fix oszlopszéles állomány beolvasása: read.fwf()

- Adattábla és mátrix kiírása tagolt szöveges állományba: write.table(), write.csv(), write.csv2()

- Egyéb input is output lehetőségek szöveges és bináris állományokkal: dget(), dput(), cat(), load(), save(), save.image()

- Adatok begépelése: scan(), fix(), edit()

- Olvasás a vágóasztalról: readClipboard()

4) Adatobjektumok létrehozása:

- Vektor létrehozása: c(), vector(), : (kettőspont operátor), seq(), rep(), sequence()

- Lista létrehozása: list(), c()

- Faktor létrehozása: factor(), gl(), ordered()

- Mátrix létrehozása: matrix(), rbind(), cbind()

- Adattábla létrehozása: data.frame(), rbind(), cbind()

5) Haladó adatkezelés az R-ben:

- Adatobjektum szerkezetének listázása: str(), ls.str()

- Adatobjektum „típusának” meghatározása: class(), typeof(), is.numeric(), is.data.frame(), is.factor()

- Típuskonverzió: as.numeric(), as.character(), as.logical(), factor()

- Elemnevek, oszlopnevek, sornevek, faktorszintek megváltoztatása: names(), colnames(), rownames(), levels()

- Numerikus változóból faktor: cut(), ifelse()

- Adattáblák egyesítése: merge()

- Adatszerkezet átalakítása: reshape(), $\operatorname{stack}(), \operatorname{unstack}()$

- Két faktor értékeinek kombinálása: interaction()

- Kereszttáblák létrehozása: table(), xtabs()

6) Matematikai és statisztikai alapfüggvények:

- Logaritmus, exponenciális, négyzetgyök és abszolút érték függvények: $\log (\mathrm{x}), \log 10(\mathrm{x})$, $\log 2(\mathrm{x}), \exp (\mathrm{x}), \operatorname{sqrt}(\mathrm{x}), \operatorname{abs}(\mathrm{x})$

- Trigonometrikus függvények: $\sin (\mathrm{x}), \cos (\mathrm{x}), \tan (\mathrm{x}), \operatorname{asin}(\mathrm{x}), \operatorname{acos}(\mathrm{x}), \operatorname{atan}(\mathrm{x})$

- Legkisebb és legnagyobb érték: $\min (\mathrm{x}), \max (\mathrm{x})$, range(x)

- Átlag, medián, kvantilisek: mean(x), median(x), quantile(x)

- Szórás, variancia, korreláció: sd(x), $\operatorname{var}(\mathrm{x}), \operatorname{cor}(\mathrm{x}, \mathrm{y})$

- Több leíró statisztikai mutató: summary(d)

- Eloszlásokkal kapcsolatos függvények: $\operatorname{dnorm}(), \operatorname{pnorm}()$, qnorm(), $\operatorname{rnorm}(), \operatorname{pt}(), \operatorname{pf}()$, pbinom() 
Magyar nyelven az R programcsomagot részletesebben ismerteti: Reiczigel és mtsai, 2007; Solymosi, 2005; Abari, 2008. Az R-rel végezhető különbségvizsgálatok matematikai statisztikai útmutatóját közli: Mező, Máth és Abari, 2008.

\section{Egymintás hatásvizsgálatokhoz szükséges adatbázis szerkezete az R-ben}

Amennyiben egyetlen (fejlesztésbe bevont) csoport vizsgálati eredményeit hasonlítjuk egy fejlesztési célként megjelölt célértékhez (vö.: Mező, Máth és Abari, 2008, 1.1. fejezet), akkor az elemzés alapját képező adatbázist egy legalább két oszlopból álló táblázatként vizualizálhatjuk. Az első oszlop a vizsgálati személyek azonosítására szolgál (név-, jeligevagy kódszám szerint), a második a vizsgált (pl. $X$ ) változó adott személyhez tartozó értékeit tartalmazza. E táblázatnak a fejlécen túl a vizsgálati személyek számának megfelelő sora van (1. ábra).

1. ábra: példa az X vizsgálati változóval kapcsolatos egymintás különbségvizsgálat adatbázisának szerkezetére (forrás: a Szerzők)

\begin{tabular}{|c|c|c|c|}
\hline \multicolumn{2}{|c|}{ Általános szerkezet: } & \multicolumn{2}{|c|}{ Konkrét példa: } \\
\hline Személy & $\mathbf{X}$ & Tanuló & IQ \\
\hline 1 & 4 & 1 & 102 \\
\hline 2 & 7 & 2 & 98 \\
\hline stb... & stb... & stb... & stb... \\
\hline 10 & 8 & 10 & 100 \\
\hline
\end{tabular}

Az 1. ábrán látható adatbázis két formában vonható be az R-rel történő további statisztikai vizsgálatokba: a) egy külső táblázatkezelő vagy szöveges fájlba rögzítjük az adatokat, s ezt a fájlt nyitjuk meg az R számára (lásd a tanulmány későbbi részét); b) közvetlenül az R-be írjuk be az adatokat a 2. ábrán látható módon.

2. ábra: $R$ adatbevitel egymintás különbségvizsgálat esetében egy d nevü adatbázisba (forrás: a Szerzők)

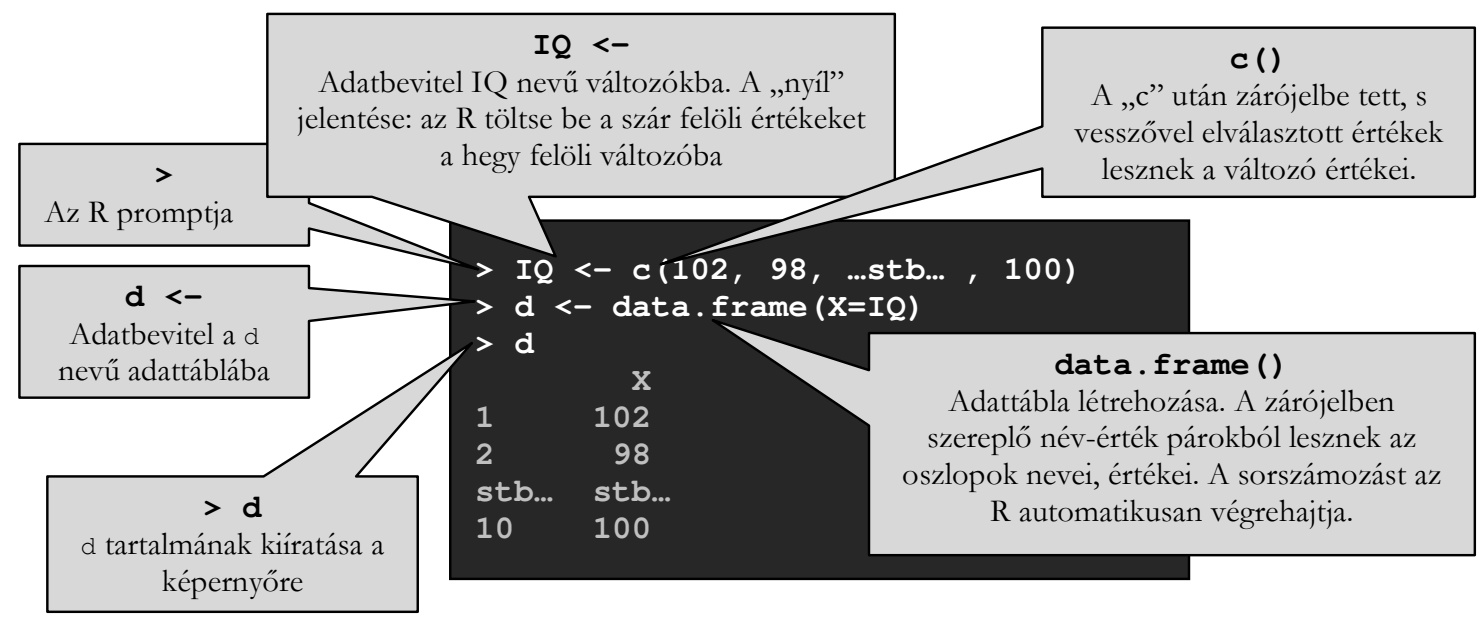


A változók skáláinak tulajdonságai (pl. kvantitatív, ordinális, nominális jellegük, eloszlásuk) függvényében az egymintás különbségvizsgálatokban alkalmazható matematikai statisztikai próbák és R parancsuk például (részletesebben lásd: Mező, Máth és Abari, 2008): Shapiro-Wilk-próba, R parancs: shapiro.test(); egymintás t-próba, R parancs: t.test(); elöjelpróba, R parancs: binom.test(); khi-négyzet-próba ( $\chi^{2}$-próba), R parancs: chisq.test().

\section{Két változós összetartozó mintás}

\section{hatásvizsgálatokhoz szükséges adatbázis szerkezete az R-ben}

Egy fejlesztőprogram önkontrollos hatásvizsgálatának sémája: elővizsgálat $\rightarrow$ fejlesztés $\rightarrow$ utóvizsgálat (Mező, Máth és Abari, 2008, 1.2. fejezet). A vizsgálati személyeket és eredményeket rögzítő adattábla ennek megfelelöen legalább három oszlopból áll. Ezek közül praktikusan az első oszlop a személyazonosítást szolgálja, a második oszlop az elővizsgálat változóját (pl. X1 változót), a harmadik oszlop az utóvizsgálat változóját (pl. X2) tartalmazza. A sorokat tekintve itt is igaz, hogy a fejlécen túl a vizsgálati személyek számának megfelelő sorból álló táblázatról van szó (3. ábra - R-be történő adatbevitellel kapcsolatban lásd: 4. ábra).

3. ábra: példa az X1 elövizsgálati és X2 utóvizsgálati változóval kapcsolatos összetartozó mintás különbségvizsgálat adatbázisának szerkezetére (forrás: a Szerzők)

\begin{tabular}{|c|c|c|c|c|c|}
\hline \multicolumn{3}{|c|}{ Általános szerkezet: } & \multicolumn{3}{|c|}{ Konkrét példa: } \\
\hline Személy & X1 & $\mathrm{X} 2$ & Tanuló & IQ1 & IQ2 \\
\hline 1 & 4 & 9 & 1 & 102 & 102 \\
\hline 2 & 7 & 9 & 2 & 98 & 105 \\
\hline stb... & stb... & stb... & stb... & stb... & stb... \\
\hline 10 & 8 & 11 & 10 & 100 & 103 \\
\hline
\end{tabular}

4. ábra: $R$ adatbevitel elö- és utóvizsgálatot magába foglaló összetartozó mintás különbségvizsgálat esetében egy d nevü adatbázisba (forrás: a Szerzök)

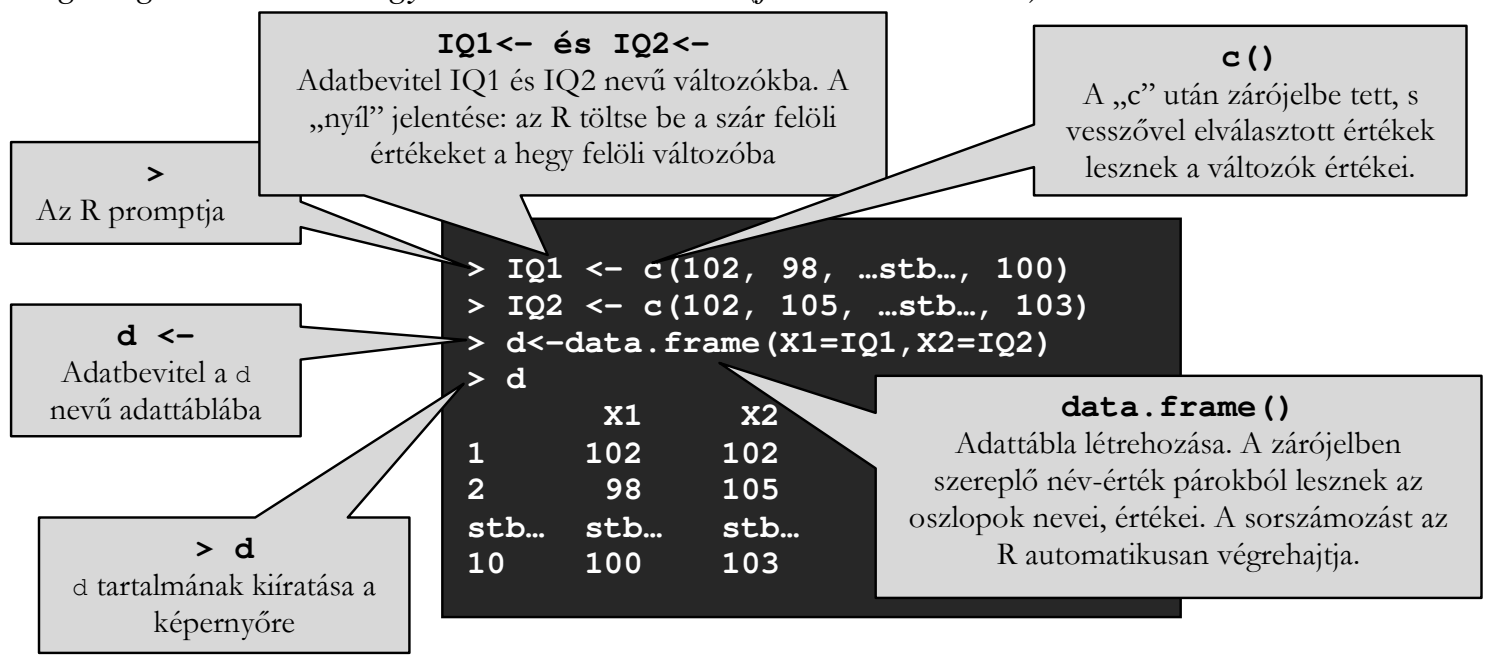


Az $R$ számára ebben az esetben is kétféle módon tehetjük elérhetővé adatbázisunkat. Az egyik lehetőség, hogy külső fájlból olvastatjuk be az adatokat - erről a lehetőségről a tanulmány végén részletesebben szólunk még. A másik lehetőség az, hogy magába az R-be írjuk be adatainkat - lásd: 4 . ábra.

A változók skálatulajdonságai (pl. kvantitatív, ordinális, nominális jellegük, eloszlásuk) függvényében az elő-/utóvizsgálat jellegű különbségvizsgálatokban alkalmazható statisztikai próbák és R parancsaik például (részletek: Mező, Máth és Abari, 2008): Shapiro-Wilk-próba, $\mathrm{R}$ parancs: shapiro.test(); páros t-próba, R parancs: t.test(); páros Wilcoxon-próba, $\mathrm{R}$ parancs: wilcox.test(); páros elöjel-próba, $\mathrm{R}$ parancs: binom.test(); McNemar-próba, $\mathrm{R}$ parancs: mcnemar.test(); marginális homogenitás vizsgálat, R parancs: mh_test().

\section{Három vagy több változós összetartozó mintás}

\section{hatásvizsgálatokhoz szükséges adatbázis szerkezete az R-ben}

Egy fejlesztőprogram nyomon követéses jellegü hatásvizsgálatában akár több éven keresztül is történhet adatfelvétel a vizsgálati személyekkel (Mezö, Máth és Abari, 2008, 1.3. fejezet). Ez azzal jár, hogy egy-egy vizsgálati személyt három vagy több alkalommal is vizsgálhatunk ugyanazon vizsgálati változó aspektusából, s ez az előzőekhez képest más adatkezelési eljárást fog kívánni tőlünk.

Amennyiben táblázatba rendezzük adatainkat, az esetek egy részében elég lehet a személyek azonosítását szolgáló oszlopot követően annyi további (pl. X1,X2..Xn nevü) oszlopot felhasználni, ahány vizsgálatot végeztünk egy-egy személlyel (5. ábra).

5. ábra: példa az X1, X2 és X3 vizsgálati változóval kapcsolatos összetartozó mintás különbségvizsgálat adatbázisának szerkezetére (forrás: a Szerzök)

Általános szerkezet:

\begin{tabular}{|r|r|r|r|}
\hline Személy & X1 & X2 & X3 \\
\hline 1 & 4 & 9 & 10 \\
\hline 2 & 7 & 9 & 13 \\
\hline stb... & stb $\ldots$ & stb... \\
\hline 10 & 8 & 11 & 7 \\
\hline
\end{tabular}

Konkrét példa:

\begin{tabular}{|r|r|r|r|}
\hline Tanuló & IQ1 & IQ2 & IQ3 \\
\hline 1 & 102 & 102 & 103 \\
\hline 2 & 98 & 105 & 105 \\
\hline stb... & stb $\ldots$ & stb $\ldots$ & stb... \\
\hline 10 & 100 & 103 & 102 \\
\hline
\end{tabular}

Az adatokat ebben az esetben is vagy egy külső fájlból hívhatjuk meg, vagy pedig a 6 . ábrán látható módon közvetlenül R-ben is létrehozhatunk adattáblát.

Azonban egyes statisztikai próbák az 5. ábrától eltérő (tehát az „egy személyhez tartozó adatok azonos sorba kerüljenek" szabálytól különböző) adatstruktúrát követelhetnek meg. Esetenként arra lehet szükség, hogy az egy személyhez tartozó $n$ számú mérés $n$ számú külön sorban szerepeljen (lásd: 7. ábra). Ekkor az az elv érvényesül, hogy „az azonos változóhoz tartozó adatértékek kerüljenek azonos oszlopba". Ebben az esetben hosszú adattáblákról beszélünk, míg az előző eset széles adattáblákat eredményez. 
6. ábra: $R$ adatbevitel három (X1,X2 és X3) vizsgálatot magába foglaló (nyomon követéses) összetartozó mintás különbségvizsgálat esetében egy d nevü adatbázisba (forrás: a Szerzők)

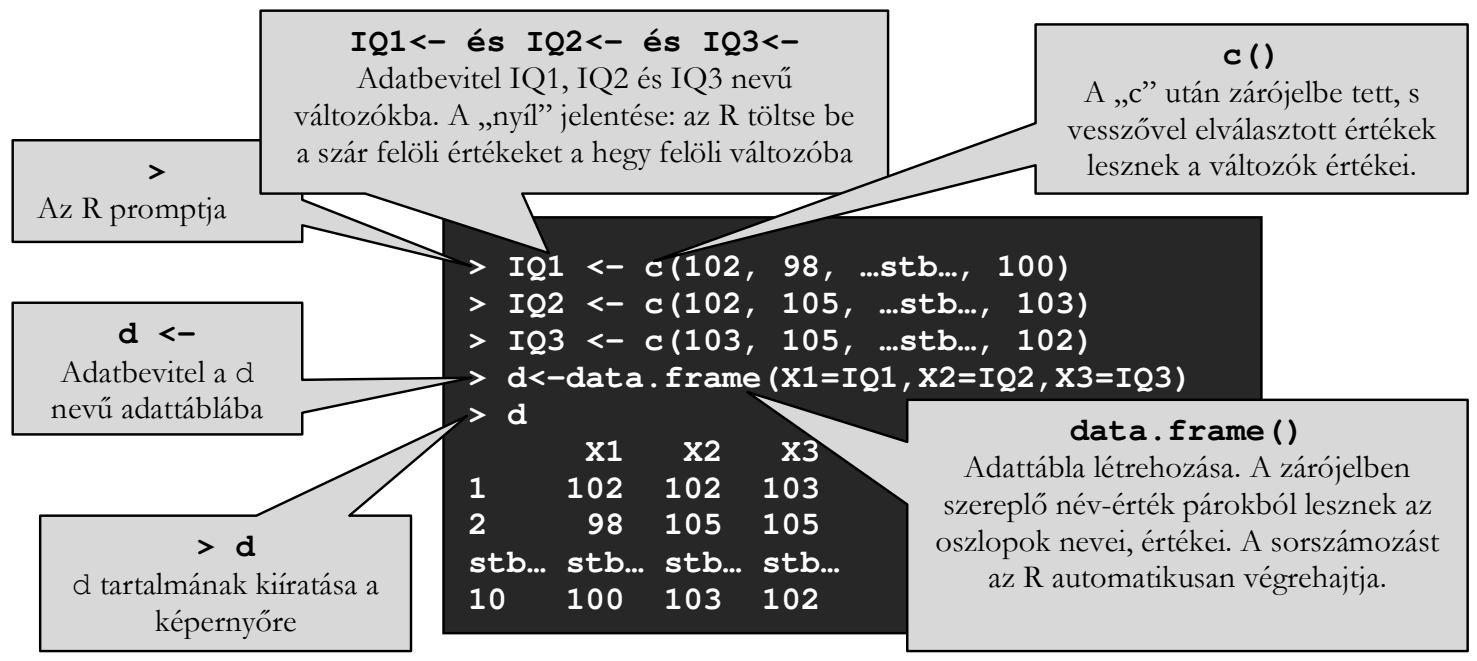

7. ábra: széles és hosszú szerkezetü adattáblák (forrás: a Szerzők)

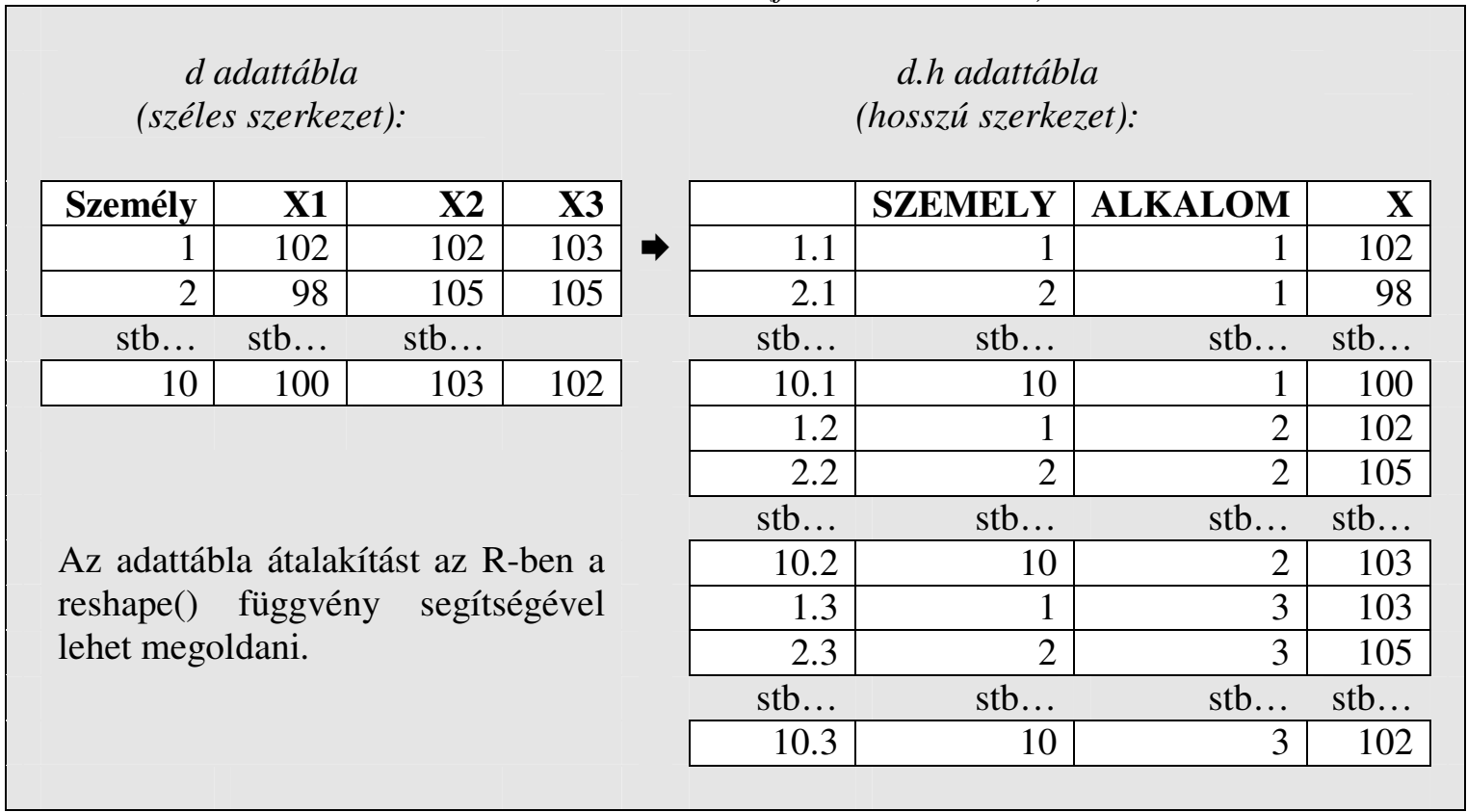

Az R-ben lehetöség van arra, hogy a 7. ábrán látható $d$ adattábla szerkezetetét néhány parancs kiadásával a szoftver transzformálja át ugyanezen ábra $d . h$ adattábla struktúrájába (8. ábra).

A változók skálatulajdonságai (pl. kvantitatív, ordinális, nominális jellegük, eloszlásuk) függvényében az elö-/utóvizsgálat jellegü különbségvizsgálatokban alkalmazható statisztikai próbák és R parancsaik például (részletek: Mező, Máth és Abari, 2008): Shapiro-Wilk-próba, $\mathrm{R}$ parancs: shapiro.test(); Bartlett-próba, $\mathrm{R}$ parancs: bartlett.test(); összetartozó mintás egyszempontos varianciaanalízis, R parancs: summary(aov()); Friedman-próba, R parancs: friedman.test(); marginális homogenitás vizsgálat, R parancs: mh_test(). 


\section{8. ábra: adattábla átstrukturálás az R-ben (forrás: a Szerzők)}

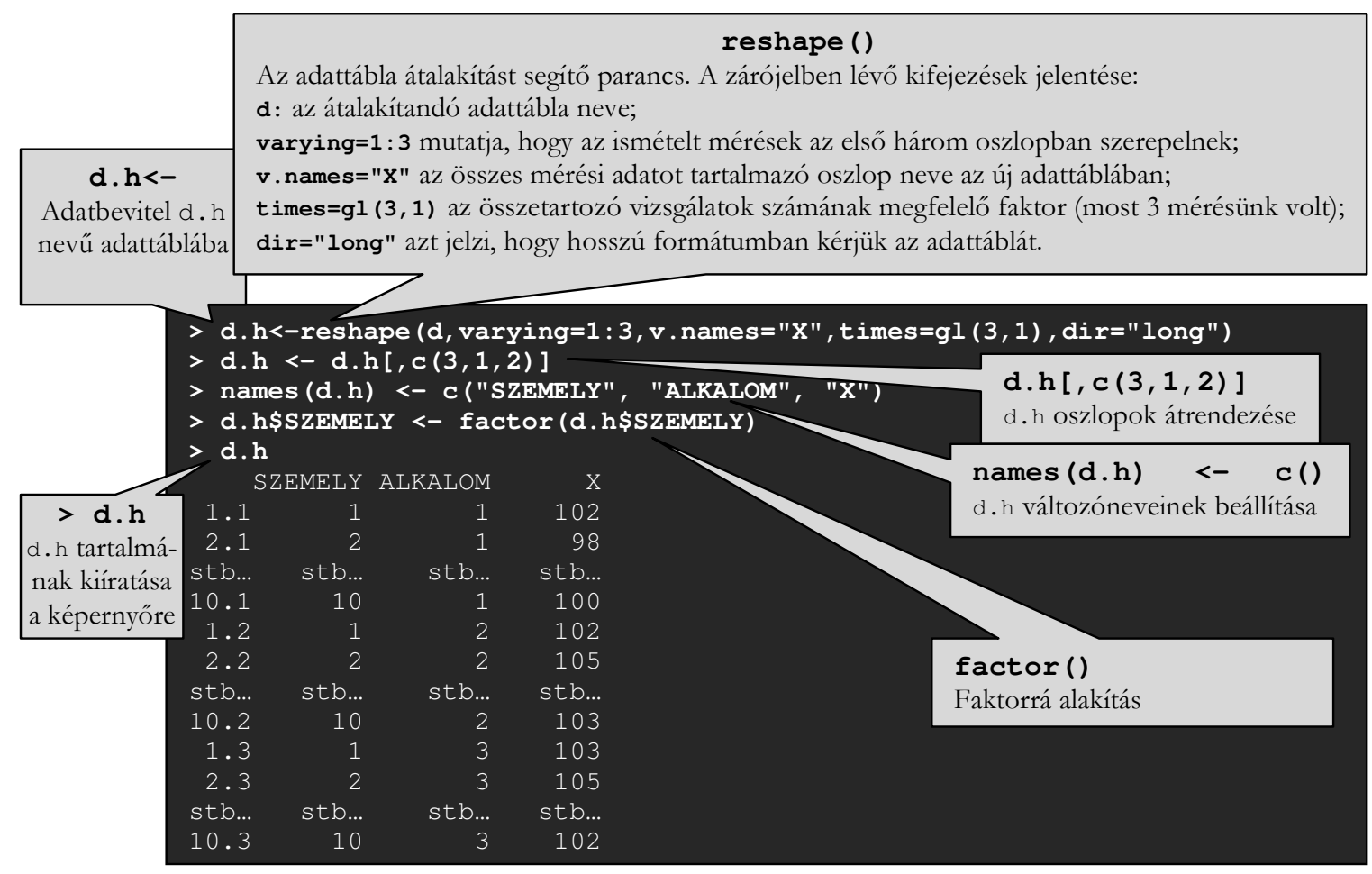

\section{Adatok beolvasása és kiírása az R-ben}

Adatok beolvasása az $R$-be: a fentiekben a hatásvizsgálatok során összegyüjtött adatainkat közvetlenül az R-ben rendeztük adattáblákká. Egy másik lehetőség az, amikor az adatokat egy táblázatkezelő vagy adatbázis-kezelő program segítségével rögzítjük, majd mentjük el szöveges állományba. Az adatok exportálása (mentése, fájlba írása) során tipikusan az adatokat elválasztó karaktert kell meghatároznunk, illetve az oszlopnevek állományba írásáról kell gondoskodnunk. Például, ha az Excel magyar változatában a „CSV (pontosvesszővel tagolt)" formátumot választjuk, akkor pontosvesszővel tagolt, oszlopneveket is tartalmazó szöveges állományt hozhatunk létre.

Tagolt szöveges állományokat (például egy c:/temp/adat.txt elérési útvonalú és nevü fájlt) a read.table() függvénnyel olvashatunk be az R-be - például:

$$
>\text { d<-read.table("c:/temp/adat.txt", header = T, sep = ";", dec = ",") }
$$

Az első argumentum a beolvasandó szöveges állomány neve, ha szükséges az elérési utat is meg kell adnunk. A header paraméterekben gondoskodhatunk az oszlopnevekröl, ha TRUE vagy $\mathrm{T}$ az argumentum értéke, akkor az állomány első sorát oszlopneveknek tekinti. Az elválasztó karaktert a sep argumentum tartalmazza. Az állomány tagolására tipikusan a szóközt (sep = " "), a tabulátort (sep = "It"), a pontosvesszőt (sep = ";") vagy a vesszőt (sep = ",’) használjuk. A szöveges állományban a tizedesvessző jelölésére használt karaktert a dec argumentum tartalmazza.

A read.table() függvény helyett használhatjuk a read.csv() és a read.csv2() függvényeket is, amelyek csak a paraméterek alapértelmezett értékeiben térnek el az alapfüggvénytől. Ezekben 
a függvényekben a header alapértelmezetten TRUE, az elválasztó karakter pedig a vessző ill. a pontosvessző, valamint a tizedesvessző alakja a pont ill. a vessző. Ha tabulátorral tagolt állományt szeretnénk beolvasni, akkor a read.delim(), ill. a read.delim2() függvényeket érdemes használni, mert az elválasztó karakter itt alapértelmezés szerint a tabulátor karakter.

Adatok kiírása az R-böl szöveges fájlba: adattáblák és mátrixok kiírására a write.table() függvényt használhatjuk. Például:

$$
\text { > write.table(szam.telj, "c:/temp/szam_telj.txt", row.names=F, sep=";") }
$$

Az első paraméter a kiírandó objektum neve, a második pedig a kimeneti állomány elérési útja. A row.names és a col.names logikai paraméterek szabályozzák, hogy a sor- és oszlopnevek szerepeljenek-e a kimeneti állományban. Ezek alapértelmezett értéke TRUE vagy T. Példánkban a FALSE vagy F értékkel letiltottuk a sorneveket. A sep argumentum itt is az elválasztó karakter alakját határozza meg. A write.table() paramétereinek alapértelmezett értékén változtat a write.csv() és write.csv2() függvény.

\section{Összefoglalás}

Tanulmányunkban azt tekintettük át és ahhoz igyekeztünk módszertani segítséget nyújtani, hogy az R program miként használható fel (gyógy)pedagógiai fejlesztőprogramok egymintás, illetve összetartozó mintás hatásvizsgálatának adatkezeléséhez. Egymintás vizsgálatról beszélünk, ha vizsgálati személyeinktől összegyüjtött adatainkat egy adott kritériumhoz (pl. fejlesztési tervben meghatározott célértékhez) hasonlítjuk. Ezzel szemben összetartozó mintás vizsgálatról van szó, ha a vizsgálati személyeinktől származó legalább két-két adatot (pl. fejlesztés előtti és utáni eredményeket) vetjük össze. Mint azt fent szintén láthattuk, a szükséges matematikai statisztikai próba megválasztása mindig függ a változó skálájától (tekintve, hogy kvantitatív, ordinális vagy nominális skálájúak-e), kvantitatív változók esetében pedig függ még a skála eloszlásától is (tekintve, hogy normális vagy nem normális eloszlást követ-e).

Noha a tanulmány terjedelmi korlátai nem tették lehetővé az $\mathrm{R}$ igazán sokoldalú lehetőségeinek bemutatását, az érdeklődők számára némi segítséget jelenthetnek azonban az alábbi segédletek:

- Az $\mathrm{R}$ használatát beépített súgórendszer segíti, bármelyik függvénnyel kapcsolatban kérhetünk segítséget a help() vagy a rövidebb ? operátor segítségével - például:

$$
\begin{aligned}
& >\text { help(t.test) } \\
& >\text { ?t.test }
\end{aligned}
$$

- További lehetőség az $\mathrm{R}$ megismerésére és a segítségkérésre a help.search(), help.start(), find(), apropos(), example(), vignette(), demo() és az RSiteSearch() függvény.

- Az R-rel kapcsolatban jelen tanulmány szándékánál és lehetőségénél mélyebb jellegü betekintést található magyar nyelven Reiczigel és tsai (2007), Solymosi (2005), illetve Abari (2008) müveiben.

- Az R-rel végezhető különbségvizsgálatok matematikai statisztikai útmutatóját közli: Mező, Máth és Abari (2008), illetve a Különleges Bánásmód folyóirat 2015. és 2016. évben megjelenő számaiban közlésre elfogadott több tanulmány is.

A fejlesztőprogramok hatásáról gyüjtött vizsgálati eredmények $\mathrm{R}$ adattáblába rendezését (s az adattábla elmentését, illetve beolvasását) követheti a leíró statisztikai, illetve a hipotézisvizsgálatra épülő matematikai statisztikai adatelemzés. A leíró statisztikai elemzés során egy tanulóra/csoportra vonatkozó átlagértékeket, szórásokat, minimum/maximum értékeke, abszolút és relatív gyakoriságokat, esetleg mediánokat vesszük figyelembe. A matematikai statisztikai elemzés ezzel szemben összetettebb, bonyolultabb számításokat, 
valószínüségi ítéletet tartalmaz. De: függetlenül attól, hogy leíró vagy matematikai statisztikai analízist végzünk-e, tartsuk szem előtt, hogy bármely statisztikai elemzés csak annyira lehet jó, amennyire a megelőző adatgyüjtési és adatrendezési munkálatok azt lehetővé teszik. Írásunkkal ez utóbbi, adatrendezési feladathoz kívántunk praktikus támogatást nyújtani.

\section{Irodalom}

Abari K. (2008): A tehetségdiagnosztika adatkezelésbeli alapjai R környezetben. In Mező F. (szerk.): Tehetségdiagnosztika. Kocka Kör \& Faculty of Central European Studies, Constantine the Philosopher University in Nitra, Debrecen. pp 105-130.

Balogh László és Mező Ferenc (2010): Tehetségpontok létrehozása, akkreditációja. MATEHETSZ, Budapest.

Máth J., Mező F., Mező K. és Abari K. (2015): Fejlesztő programok hatásvizsgálatának matematikai statisztikai alapfogalmai. Különleges Bánásmód, 2015, I/1. 69-77.

Mező F., Máth J. és Abari K. (2008): A különbségvizsgálatokon alapuló tehetségdiagnosztika matematikai statisztikai alapjai (adatelemzési útmutató). In Mező F. (Szerk.): Tehetségdiagnosztika. Kocka Kör \& Faculty of Central European Studies, Constantine the Philosopher University in Nitra, Debrecen. pp 131-207.

Reiczigel J., Harnos A. és Solymosi N. (2007): Biostatisztika nem statisztikusoknak. Pars Kft., Nagykovácsi.

Solymosi N. (2005): R<-...erre, erre...! Internetes R-jegyzet. Letöltés: 2015.09.14. Web: http://cran.r-project.org/doc/contrib/Solymosi-Rjegyzet.pdf 
KÜLÖNLEGES BÁNÁSMÓD, I. ÉVF. 2015/2. 


\title{
HIPERAKTÍV GYERMEK AZ OSZTÁLYBAN
}

Szerzők:

Nagy Lehocky Zsuzsa

Nyitrai Konstantin Filozófus Egyetem

(Szlovákia)

Patai Ilona

Nyitrai Konstantin Filozófus Egyetem

(Szlovákia)

Első szerző e-mail címe: znlehocka@ukf.sk

\section{Lektorok:}

Szabó Edina

Debreceni Egyetem

Szilágyi Barnabás

Debreceni Egyetem

Schréder Veronika

Debreceni Egyetem

Mező Katalin

Debreceni Egyetem

Nagy Lehocky Zsuzsa és Patai Ilona (2015): Hiperaktív gyermek az osztályban. Különleges Bánásmód, I. évf. 2015/2. szám, 49-58. DOI 10.18458/KB.2015.2.49

\begin{abstract}
Absztrakt
Az utóbbi évtizedben fokozott mértékben elötérbe került a hazai és külföldi pedagógiában egyaránt a tanulási és magatartászavarral küzdö gyerekek iskolai nevelésének problémája. A pedagógusok annak ellenére, hogy egyre gyakrabban tanítanak hiperaktív gyermeket, nincsenek rá kellöképpen felkészülve. Részükről a gond abban rejlik, hogy képzésük során nem ismerkedtek meg azokkal a módszerekkel, amelyek segítségével egyénileg fejleszthetöek a nehezen nevelhetö, problematikus személyiségü tanulók. A hiperaktivitás felismerésére és megítélésére a bizonytalanság és a végletek jellemzőek, mert minden túlmozgásos és eleven gyermeket lassan hiperaktívnak titulálnak. A zavarok korai kiszürése pedig lehetövé tenné, hogy a gyermekek időben, megfelelö segítésben részesüljenek.

A következö tanulmány két fö részböl, elméleti, illetve gyakorlati részböl áll. A gyakorlati rész konkrét esettanulmányokat mutat be, segítve ezzel az időbeni felismerést. Három hiperaktív gyermek viselkedésformáit, a rájuk jellemzö tüneteket fejtjük ki bövebben, figyelembe véve a családi és iskolai körülményeket. Felsorakoztatjuk a segítségnyújtás formáit az iskolában, konkrét ötletekkel, tanácsokkal látjuk el a pedagógusokat.
\end{abstract}

Kulcsszavak: hiperaktív, pedagógus, esettanulmány, segítségnyújtás

Diszciplínák: pszichológia, pedagógia

\begin{abstract}
HYPERACTIVE CHILD IN THE CLASS

In the last decade, the issue of school education of children struggling with learning and behavioural disorder has come to the front in domestic as well as foreign pedagogies. The recognition and judgment of hyperactivity is characterised by uncertainty and extremes since increasingly all lively kids with excessive movement are labelled hyperactive. In turn, early detection of the disorders would enable children to get appropriate help.
\end{abstract}


The following study consists of two main parts: a theoretical and a practical one. The practical part introduces concrete case-studies assisting the early detection. The behavioural forms of three hyperactive children and their characteristic symptoms are explicated more broadly taking into consideration the family and school circumstances. It also aligns the forms of assistance and help in schools and gives concrete ideas and advice to teachers.

Keywords: hyperactive, pedagogue, case-study, assistance

Disciplines: psychology, pedagogy

Az iskolakezdés rendkívüli változásokat jelent egy gyermek életében. Nemcsak az otthoni helyzete változik meg valamilyen szinten, hanem az iskola által felállított követelményeknek, előírásoknak, szabályoknak való megfelelés is nehéz feladat elő állítja a gyermeket. A hiperaktív gyerekeknek mindez még nagyobb megpróbáltatást jelent. Hiszen a hiperaktivitás, egy olyan magatartásbeli zavar, melynek során az egyén nem tudja figyelmét tartósan egy dologra összpontosítani és állandó mozgásra van szüksége.

\section{Történeti áttekintés}

A hiperaktív gyerekek egyik legrégebbi és egyúttal legismertebb ábrázolása Heinrich Hoffmann 1845-ben megjelent müve, a Struwwelpeter (Kócos Peti). E müben olvasható rövid tanmesék hőse csupa olyan gyerek, aki valamilyen gondot okoz a szüleinek. Az egyik történet kis hőse - Zappel Philipp - a hiperaktivitásban szenvedő gyerek minden tüneti sajátosságával rendelkezik.

A 20. század elején az angol dr. George Stiel ezeket a gyerekeket „akaratgyengének“ nevezte, a magatartás erkölcsi kontrolljának komoly zavarával, de nem zárta ki az esetleges neurológiai eredetet sem.

1934-ben Kahn és Cohen nevezte ezt a jelenséget „organikus nyugtalanságnak“.

Valamivel később Charles Bradley (1937) leírta a hiperaktív gyerekek tüneteit és bizonyos serkentő szerek adagolásával jó eredményeket ért el, a tünet-együttes pedig a „nyugtalansági szindróma“ elnevezést kapta.

A 60-as években, föleg Amerikában óvatosabban kezdtek bánni azzal a kijelentéssel, miszerint a szülők tehetők felelőssé a tünetek kialakulásáért.

A „minimális cerebrális diszfunkció“ (MCD) elnevezést Berger vezette be 1977-ben, amelyet néhol még ma is használnak.

Később a szindróma az „Attention Deficit Disorder“, ADD elnevezést kapta, amelyet „figyelemzavar tünetegyüttesként“ fordíthatnánk le, később megjelent a figyelemzavar hiperaktivitással együtt (ADHD) megnevezés.

Ehrat és Matmüller-Frick magyar fordításban megjelent müve „A nehezen kezelhető gyermekek (POS)“ pszichoorganikus szindrómáról beszél.

1994-ben a figyelemhiánnyal járó rendellenesség új nevén figyelemhiányos/hiperaktivitászavar tünetegyüttesként jelenik meg.

A szakirodalom tehát sokféle elnevezéssel jelöli a tünetcsoportot: MCD (Minimális agyi diszfunkció), POS (Pszichoorganikus szindróma), HKZ (Hiperkinetikus zavar), ADD (Attention Deficit Disorder, figyelemhiányos rendellenesség), ADHD (Attention Deficit Hyperaktivity Disorder, figyelemhiányos hiperaktivitás rendellenesség), FIMOTA (figyelemzavar - mozgászavar - tanulászavar). 
$\mathrm{Az}$ alaptüneteket három differenciáldiagnosztikai kategóriába rendezik, úgymint figyelemzavar (elkezdett cselekvés abbahagyása, feladatra összpontosítás nehézsége, fokozott elterelhetőség játék során is, stb.), impulzivitás (gondolkodás nélküli cselekvés, szervezetlen feladatvégzés, folyamatos felügyelet igénye, stb.) és hiperaktivitás (extrém expanzív viselkedés, állandó mozgás, nyugtalanság alvás közben is, stb.).

A gyakorisági felmérések adatai meglehetősen ellentmondásosak. Az 1980-as évek vizsgálatai szerint a gyermekkori hiperaktivitás előfordulása 5-10\%. Ugyanakkor az 1990-es évek kutatásai alapján a 3-5\% gyakorisági adat a nemzetközi szinten elfogadott arány. Jelenleg is az ADHD epidemiológiája az iskoláskorú gyermekpopulációban 3-5\%, a fiúk körében jóval gyakrabban fordul elő.

\section{Módszer}

A jelen tanulmány részletesen bemutat három esettanulmányt, melyek alátámasztják azt a feltételezést, hogy a hiperaktív gyermek szülei,t illetve pedagógusait is fel kell készíteni ezen gyerekekkel való különleges bánásmód lehetöségeire.

Az esetelemzések kidolgozása során a következő kutatási módszereket alkalmaztuk:

- Anamnézis (kórelőzmény), amely nem más, mint szóbeli kikérdezés, mellyel az volt a célunk, hogy a vizsgált jelenség előzményeit feltárjuk.

- Interjú, mint kutatási módszer: azért tünt a legcélravezetőbbnek, mert ezzel lehetett a legtöbb, nagyobb mélységeket tükröző információkhoz jutni. Az interjúkat a szülőkkel végeztük el.

- Megfigyeléseink során nyomon követtük a gyermekek viselkedésformáit, megnyilvánulásait (otthon és az iskolában).

- A Conners-féle minősítő skála szülői és pedagógusi változatát alkalmaztuk.

\section{Minta}

A vizsgálatban több gyermek is részt vett, de jelen tanulmányban három esetet mutatunk be részletesen.

\section{Eszközök}

A Conners-féle rövidített tanári minősítő skála (Conners, 1988) a gyermekkori hiperaktivitás vizsgálatánál alkalmazott ismert eljárás. Az iskolai környezetbeli tartós megfigyelésre épülő, 10 viselkedéses jellemzőt tartalmazó szempontsor a figyelemzavarhiperaktivitás szindróma különböző minőségü és súlyosságú tüneteit fejezi ki. A pedagógus mind a 10 viselkedési minősítő kategóriáról eldönti, hogy azok milyen mértékben jellemzőek a kérdezett gyermekre. Meg kell jegyezni, hogy önmagában ez a skála nem alkalmas a diagnózis felállítására, a hivatalos diagnosztizáláshoz több terület szakemberei általi vizsgálat és vélemény szükséges.

A kiválasztott esettanulmányban két fiú és egy kislány történetét mutatjuk be, akik mindannyian diganosztizáltan is sajátos nevelési igényü gyerekek. Alsó tagozatos tanulókat választottunk, hiszen esetükben is a korai segítségnyújtás volt az elsődleges szempont.

\section{Kérdések}

A következő kérdések megválaszolására törekedtünk az esetelemzések elvégzése során. 
1. A terhesség és a szülés lefolyása milyen volt? Jelentkeztek-e komplikációk? (Mivel a szakemberek véleménye szerint a terhesség és a szülés lezajlása nagymértékben befolyásolhatja a hiperaktivitás kialakulását)

2. A szakirodalom által leírt tünetek ténylegesen jellemzik-e a vizsgált gyermeket?

3. Az igazi problémák az iskola szabályokkal irányított rendszerében felerősödtek-e?

4. A hiperaktív gyermekeknél fellépnek-e tanulási zavarok vagy bármilyen problémák, amelyek akadályozzák a tanulásban?

5. Miként viselkedik az ADHD-s gyerek a társas térben, mikro- és makrotársadalmi szinten?

6. Hogyan viszonyulnak a problémához a szülők, az óvoda és az iskola?

\section{Eredmények, esettanulmányok}

Szándékunk szerint esettanulmányaink bemutatása ahhoz járulhat hozzá, hogy a pedagógusok egységes, konkrét képet alkothatnak a hiperaktív gyerekek jellemzőiröl.

\section{1. esettanulmány:}

Zs., 8 éves tanulónál figyelemzavar és hiperaktivitás állapítható meg az eddigi vizsgálatok és tapasztalatok alapján. A Conners-skála alapján végzett kiinduló teszt eredménye 20 pont volt.

A terhesség 42. hetében született, 3500 grammal és 52 cm-rel, császármetszéssel a túlhordás miatt. Az anyuka elmondása alapján már magzatkorban is igen aktívnak bizonyult, az átlagnál többet és jóval intenzívebben mozogott. Félő volt, hogy emiatt koraszülés lép fel.

Csecsemőként nehezen volt nyugtatható, sokat és sokáig sírt, sokszor minden különösebb ok nélkül. Gyakorlatilag éberen aludt. Napközben és éjszaka is a kevés alvásigény volt rá jellemző. 10 hónaposan már ment egyedül. Kisgyermekként örökmozgó, temperamentumos és akaratos, az óvodában elevennek, igazi kis vadócnak tartották. Az óvodai jellemzésében szerepelt, hogy rajzai kusza firkák, túl halványak vagy túl erösek a vonalai, görcsösen fogja a ceruzát, a formák másolása, emberrajzai felismerhetetlenek, elnagyoltak. Nem tud vonal mentén nyírni, általánostól nagyobb ügyetlenség jellemzi a kézmüves tevékenységekben. Ügyetlen az apróbb játéktárgyakkal való játékokban. Figyelme szakaszos.

Nagyon mozgékony. Domináns a csoporton belül. Szokatlanul hangos és impulzív kitörései vannak. Veszélyérzete csekély, gyakran éri és érte őt baleset. Az óvodai séták során hangsúlyosan kellett figyelni rá, gyakran lelépett a járdaszélről, és kifutott az úttestre. Pedagógusainak köszönhetően, nem volt ebből kifolyólag balesete. A játszótéren viszont az impulzivitása miatt mindig adódtak balesetek, leesett a mászókáról, lelépett a mászóka magasabb fokáról, mert nem tudta felmérni a helyzetet, a labdajátékok alatt folyamatosan elesett a saját lábában, a többiekkel sem tudott közremüködni, mert a játékokat idő elött „megunta” és tovább állt. Szülei beíratták egy sportkörre, ahol a rossz mozgáskoordinációs nehézségekre irányuló sporttevékenységekkel és játékokkal foglalkoznak.

Iskolaérettsége nem volt megfelelő, amit a pszichológiai tesztek is igazoltak, ezért egy évet halasztottak. Viselkedését szocializálhatónak minősítették, agresszív jellemvonásokkal. Finommotorikája kezdetleges, figyelme szétszórt, önbizalma normában volt, de kiemelten a részképességzavarok miatt ajánlották az egy év halasztást. Relációkészsége, tartalmi következtetése, íráskoordinációi nem érték el a norma határát.

Nagy benne az újdonság iránti igény, ami az iskolában is megfigyelhető. Ennek következtében gyakran fordul elő, hogy nem tudja végigülni a tanórákat. Különösen akkor, ha számára kevésbé érdekes a tananyag, vagy csak egyszerüen nem sikerül felkelteni és fenntartani az érdeklődését. Ilyenkor unatkozni kezd, és elkezd magának érdekesebb elfoglaltságokat találni. Zavarja a tanórát, beszélget, játszik, olvas, esetleg feláll valamilyen 
mondvacsinált ürüggyel, csak hogy végre mozoghasson egy kicsit. Írása rendezetlen, sok külalaki és helyesírási hibával. Zs. balkezes, ami miatt a szülők nehezebben tudtak segítséget nyújtani az írás elsajátításánál. Olvasása a másodikos osztályos szintnek felel meg, diszlexiás és diszgráfiás jegyekkel. A nyelvtan és olvasás órákat nem szereti. Nehézséget okoz számára egy hosszabb szöveg elolvasása és értelmezése. A szövegértési feladatait akkor teljesíti sikeresen, ha rövidebb a feldolgozandó anyag, egyszerüek a kérdések és számára érdekes a téma.

A figyelemzavar miatt a helyesírása gyenge, gyakori ékezethibával, mivel nem olvassa el maga után a szöveget. A matematikát, a természet- és honismeret órákat kedveli, a feladatokat idő előtt elvégzi, bár gyakran ejt hibákat a figyelmetlensége miatt, pl. hogy nem olvassa végig az elvégzendő feladatokat. Az iskolai munka menetét a gyakori beszólásaival és türelmetlenségével megzavarja. Osztálytársai nehezen viselik, hogy mindenbe beleszól és elsőként füz megjegyzést. Tanító nénije ismerve terhelhetőségét és érdeklődését mindig készít önálló feladatokat a tanórákra. Ezeket az önálló feladatokat gyorsan megcsinálja. Általában gyorsabban dolgozik, mint a többiek, ami további problémák forrása, hiszen ha végzett a feladattal és még várni kell a többiekre, unatkozni kezd, és biztosan talál magának elfoglaltságot. A feladatok megoldásának minősége nagyban függ attól, hogy milyen témát kap, hangsúlyosan tekintettel kell lenni sajátos igényeire. Lehetőséget kell biztosítani számára a mozgást tanóra közben, tehát ő szokta letörölni a táblát, segíteni, felakasztani a térképet, kiosztani a dolgozatokat vagy a feladatlapokat. Terhelni kell őt, hogy ne legyen ideje unatkozni. Az óvodában is ö terített, osztotta ki a lapokat, segített megvetni az ágyakat.

A testnevelés órákon nagyon aktív, nincs kiemelkedő sportteljesítménye, sem érdeklődési köre, csupán szeret mindenben részt venni. Sportkörre és futballra jár heti 1-1 alkalommal, nem jobb és gyorsabb a többieknél, csak állandóan mozgásban kell lennie. Hipermobilitása a szülők elmondása szerint sokszor eredményezi a térdei, lábfeje és bokái erős fájdalmát a nap végén, vagy éjszaka.

Nem viseli jól a bezártságot és a kötött rendszert. A napköziben gyakran feláll, sétál a teremben, többször kikéredzkedik a mosdóba, hogy a folyosón futhasson egyet. Átlagnál gyorsabban fejezi be a házi feladatait. Játék közben szintén megfigyelhetőek a hiperaktivitásra utaló jelek: a kirakós, logikai játékokat, kifestőket nem részesíti előnyben. A mozgást igénylő játékok kötik le, de nem jó csapatjátékos, nem viseli el, ha valaki lassúbb vagy jobb teljesítményre képes, mint ő.

Sok esetben haragos, akaratos és makacs, együttműködésre nem hajlandó. A család elmondása szerint folyamatos konfliktusforrás, hogy nem viseli el öccse „lassúságát”, megfontoltságát és hogy nem partnere a kedvenc játékaiban. Nehezen tud együttmüködni másokkal, látszólag nem törődik a másik érzéseivel, hajlamos a basáskodásra. Mindig ő akar a vezér lenni - mondják az osztálytársai és öccse is. Nem feltétlen az a célja, hogy irányítsa a játékot, hanem nem tudja elviselni, ha nem történik azonnal az, ami eszébe jutott. Emiatt is az iskolában a többi gyerek kiközösíti.

A családi közös étkezések alatt sem bír folyamatosan egy helyben maradni, ami megfigyelhetö az iskolai étkezdében is. A terítésnél a legaktívabb, elsőként végez az evéssel, nem várja meg, míg a többiek befejezik, ilyenkor szórakoztatja a többieket, asztal alá mászik.

Gyakori dühkitörései miatt, pszichológiai és pszichiátriai kivizsgálások sora után, a szakemberek centedrin típusú nyugtatók használatát javasolták, mert a hagyományos nyugtatóktól még inkább impulzívabbá vált.

2. esettanulmány:

S. tünetei igen változatosak, mégis jól körülírhatók. A Conners-skálán 25 pontot ért el. Érdekes, hogy 10 és fél hónaposan már futkározott, egyedül viszont csak 3 évesen tanult meg enni és inni. Kerékpárjáról csak elsős korára vették le a pótkereket, mert figyelmetlensége 
miatt állandóan balesete volt. Észlelése ugrándozó, a feladatokat elsőre nem érti meg, nem képes folyamatosan odafigyelni. Mindez problémát okoz többek között a matematika tanulásánál, főleg a szöveges feladatok megoldásánál. Az egyszerübb matematikai feladatokkal még viszonylag gond nélkül megbirkózik, de szöveges feladatoknál nem érti az állítások közti összefüggéseket. Geometriából az egyszerübb tér és síkalakzatok szerkesztésénél egyfajta térészlelési zavar figyelhető meg nála. Képtelen sorrendiséget felállítani, nemcsak a feladatokban nem tudja ezeket követni, hanem mindennapi tevékenységében sem tudja, hogy mi a fontosabb. Képtelen az idejét hasznosan és megfontoltan beosztani, ezért sokszor lemarad a többiektől. Önálló tanulásra nem képes, folyamatos felügyeletet kíván, nemcsak tanulási zavara miatt, hanem viselkedési zavar miatt is. Gyakran mondják a szülei, hogy "mindent megígér, de semmit nem tart be", mindig halogatja a leckét azért, hogy kibújjon a feladat alól, vagy sokáig ül a könyv mellett, mégsem jut előbbre.

Óvodás kora óta észlelhető volt hirtelen temperamentuma, hamar nyugtalanná vált. Nem viselte el a kudarcot semmilyen formában. Öntörvényü, gyakran alkudozott, makacs és akaratos. A játékszabályokat gyakran megszegte, ami számtalanszor komoly konfliktusokhoz vezetett. Barátai nincsenek, mindenki elpártolt tőle impulzív természete miatt. A játszótéren tönkretette mások játékait, direkt módon bosszantotta a többieket. Az óvodában nehezen birkózott meg a finommotorikát igénylő feladatokkal. Nehezen szocializálható.

Az iskolaérettségi vizsgálaton intellektuálisan érettnek véleményezték, megjegyezték, hogy szabálytartása, feladattudata gyengébb, szociálisan kissé éretlen. Képességei nem térnek el jelentősen az átlag gyerekekétől az iskolában, de ha nem öt szólítatják fel, vagy nem az ö füzetét nézik meg elöször, indulatossá válik, durcás lesz. Mivel decemberi születésü, egy évvel később kezdte az első évfolyamot. Írni és olvasni gyengébb kimenetellel tanult meg, írásképe rendezetlen, olvasása most harmadik évfolyamban is lassúbb és szaggatottabb az átlagnál.

Képtelen a tanítási órákat nyugton végig ülni, mindent kommentál. Folyton babrál, valamije mindig lepottyan, kidöl, vagy éppen a társa holmiját borítja le. Minden mozdulatát hangosan kommentálja. Az iskola és tanító nénije kezdetben nagyon toleránsnak tünt, jelezték a nehézségeket, de bíztatták a szülőket, hogy majd csak belerázódik az iskolás életbe. Második osztály végén váratlanul érte a családot a gyermekről kapott gyenge bizonyítvány a javaslattal, hogy viselkedése, éretlensége miatt ne menjen felsőbb osztályba. A szülök kérésére azonban folytatta tanulmányait. A helyzet nem változott, sőt, a problémák súlyosbodtak, nyíltan megtagadta a tanulást, állandóan zavarta a tanítást, provokálta a tanító és nevelő nénijét. A harag és a düh háttérét nem értették, míg a szülők gyermekpszichiáterhez vitték, megtörtént a kivizsgálás, a figyelemzavar-hiperaktivitás igazolódott. Kognitív viselkedésterápiában részesül (Ayres terápia).

\section{3. esettanulmány:}

K. elsős kislány, akinek súlyos beilleszkedési zavarait hiperaktivitása okozza. A Conners skálán 29 pontot ért el.

A terhesség átlagosnak mondható volt, két alkalommal mértek magasabb vérnyomást, ettől eltekintve minden norma szerint folyt. A születést követően a dolgok viszont megváltoztak, a család élete teljesen felbolydult. K. rendkívül nyugtalan csecsemő volt, anyja szinte 2 évig nem aludt, állandóan sírt, rosszul evett. Anyukája egy idő után már nem is tudta megnyugtatni. Úgy érezte, nem jó anyja a kislányának, talán nem szereti őt a gyermeke. Viszonylag korán, 9 és fél hónaposan elindult egyedül. Az oviban csak két óráig lehetett a csoportban kezelhetetlen agresszivitása, nyugtalansága miatt. Az iskolában is hasonló volt a helyzet, emiatt nem járt napközibe. Társai nem szívesen játszanak vele. Gyakran bosszantja a 
gyerekeket, úgy próbál kapcsolatot teremteni, hogy megzavarja őket, pl. az óvodában lerombolta a többiek által épített várat, tornyot, az iskolában összefirkálja mások füzeteit, elveszi a tízóraijukat.

Gyakorlatilag csak szaladgálva közlekedik. Önállótlan, nem tud elhatározni és végrehajtani. Nem tudja viselkedésének következményeit a jövőre előrevetíteni. Ugyanígy a múltat sem tudja a jelenhez megfelelöen kapcsolni, vagyis úgy tünik, nem tanul az állandóan hangoztatott hibákból. Csak az "itt és most" létezik számára. Nem tud nyugodtan étkezni, nem tud türelmesen ülni az asztalnál. Iskolás kora előtt szinte soha nem tudták hosszabb ideig feladathelyzetben tartani. Mindent hamar megunt, semmi sem kötötte le. Édesanyja otthoni munkát vállalt, mivel egy percre sem hagyhatja magára. Mindenhova felmászik, leugrik.

Rendkívül kíváncsi. Semmivel nem tudja magát lefoglalni, gyakran segítséggel sem. Nem képes egy mesét sem végighallgatni. Mindig mást csinál, mintha nem is hallaná, amit mondanak neki. Tévé mellett sem marad meg hosszabb ideig. Játszása abban merül ki, hogy kiönti játékait a szoba közepére és további elfoglaltság után néz.

Az anyuka félve járt gyermekéért az óvodába, iskolába, hiszen minden alkalommal történt valami galiba. A szülők egy idő után úgy érezték, elveszítették minden kapcsolatukat, elmaradtak a barátaik. Kislányuk felügyeletét már egyetlen nagyszülő sem vállalta, miután mindig adódtak balesetek. Ezen problémák miatt eléggé elromlottak a családi kapcsolatok, felelősség és bünbakkeresés folyt. Ismerősük ajánlására fordultak szakemberhez. A kivizsgálást követően figyelemzavar-hiperaktivitás mellett súlyos beszédértésbeli zavart állapítottak meg. Gyógyszeres kezelés nem volt szükséges, mert megfelelő gyógypedagógiailogopédiai fejlesztésben részesül heti három alkalommal.

Az iskolát egy év késéssel kezdte, ez idő alatt a speciális pedagógus mellett az anyuka is rengeteget foglalkozott gyermeke fejlesztésével. A szülők képzésben, tréningen vesznek és vettek részt, hozzáállásuk változott, felszabadultabban, határozottabban, pozitívan igyekeznek szabályozni kislányuk viselkedését. Az iskolai feladatok megvitatásában is partnerek, jól tudják kezelni lányuk állapotát és helyzetét. A szülők nem szeretették volna speciális iskolába íratni lányukat, külön kérvényezték lányuk állapotára való tekintettel, hogy átlagos iskolában tanulhasson. Szakpedagógus, szociálpedagógus és pszichológus segítségével hangolták össze a tananyagot számára, hogy ne legyen lemaradása a többiekkel szemben, és hogy a tanítás menete és minősége sem csorbuljon. Közös megegyezéssel a napközis oktatásban nem vesz részt, az adottságaira alapozva oktatják őt otthon szülei. K. fizikailag terhelhetőbb, szellemileg kevésbé. A motorikája sokat fejlődött, bár a házi feladat írása még mindig a legmegosztottabb programok egyike, de jelenleg úgy tünik, meg fog birkózni vele. Jobbkezes. A szótagoló olvasást játékos mozgásos formában tanulják, ezt ügyesen befogadja. Tanító nénijük ötletes mozgásos, dalos játékokat is beépít/ett a tanórákba, hogy ezzel is lehetőséget biztosítson mozgásigénye kielégítésére, ez egyébként normális és elvárt ebben az évfolyamban. A szülők aggódnak, hogy a felsőbb évfolyamokban, mikor már a tananyag mennyisége és az idő rövidsége nem teszi mindezt lehetővé, mi lesz lányukkal.

A pedagógus szándékos szófogadatlanságnak tartja viselkedését és ennek visszajelzésére az adott tantárgyból elégtelen érdemjegyet alkalmaz. A pedagógus eszköztelenségét jól tükrözi a beírások sokasága, fekete pontok. Ennek a módszernek az alkalmazása a hiperaktív gyereknél a teljesítmény teljes visszaesését, a tanulás iránti motiváció elvesztését eredményezi.

\section{Segítségnyújtás az iskolában}

A gyermek otthon biztonságban érzi magát, szülei szeretik és elfogadják őt olyannak, amilyen. Ha viszont bekerül idegen gyerekek közé, és egy idegen felnőtt mondja meg neki, hogy mit csináljon, akkor rendkívül bizonytalanná válik, az ingerek közül nem tud szelektálni, szétesik, magatartása az új helyzetek miatt zilálttá válik. Félelmetes és nyomasztó 
érzés ez számukra. A hiperaktív gyerekek állandó és még alaposabb, átgondoltabb felkészülést igényelnek a tanároktól, igazságot, határozottságot, türelmet és sok-sok humort kívánnak.

A következőkben összefoglalunk néhány olyan tanácsot, mely segítheti a munkát egy olyan osztályban, melyben hiperaktív gyermek is jelen van.

\section{Hová ültessük az osztályban a gyerekeket?}

Legjobb az első padba ültetni, középre, mert így kevéssé vonják el figyelmét a különböző dolgok: nem bámészkodik ki az ablakon, az ajtónál ki-bejárnak, hátul ülve minden előtte zajló történésre felfigyelne. Mivel a figyelme nagyon hamar elterelödik, egyszerü és ingerszegény környezetre van szüksége. Sokszor segíthet, ha csendes, szorgalmas, nyugodt társ mellé ültetik.

\section{Magyarázat}

Fontos, hogy mindig teremtsünk vele szemkontaktust. Lassan, érthetően és röviden magyarázzunk. A feladatokat több lépésben adjuk meg, mindig csak egy dolgot kérjünk tőle. Ellenőrizzük, hogy megértette-e a feladatot. Igyekezzünk őt emocionálisan motiválni. Minden új információt próbáljuk meg meghatározott rendszerrel bevezetni, használjunk képeket, diagramokat, ábrákat, szemléltessünk mindent. A figyelmük hosszabb ideig fenntartható, ha minél több érzékszervet kapcsolunk be.

Segítségnyájtás a munka szervezésében

Fontos a tervezés, hogy a gyerek képes legyen lebontani a feladatokat, különben reménytelennek érzi magát és nem tudja elvégezni a feladatot. A padon tanítsuk meg elrendezni a dolgait, semmi felesleges dolog ne maradjon ott, mert eltereli a figyelmét.

\section{Önállóság növelése}

Bevezethetünk saját leckefüzetet, ahova saját maga, padtárs vagy akár tanár is bejelölheti a leckét. Kevesebb házi feladatot adjunk, hiszen nekik minden sokkal több időd vesz igénybe. Praktikus lehet tanulási útmutató tervezése otthonra.

\section{Számonkérés}

Lehetőség szerint ez legyen egyéni számonkérés, legjobb és legkönnyebb ezeknek a gyerekeknek a szóbeli feleltetés. Mivel a kézírásuk gyakorta olvashatatlan, rendetlen, ezért sohase a külalakot értékeljük. Az írás kuszasága, szaggatottsága, a betűk nagyságának egyenetlensége, a nehézkes, görcsös írásmód, a szem és kéz koordinációjának problémáival hozható összefüggésbe. A kézírás minőségére súlyosbítóan hat a csekély figyelmi feszültség is.

\section{Önkontroll erösítése}

A gyerekek maguk is érzik a nyugtalanságot és szeretnének változni, ezért fontos a követelmények pontos megfogalmazása. Megegyezhetünk a gyerekekkel bizonyos szabályokban, mint például:

1. A tanítási órákra rendszeresen készülök.

2. Az osztálytársaimmal és a felnőttekkel kedves és tisztelettudó leszek.

3. Az önálló munkák alatt nem zavarom az osztálytársaimat.

4. Ha valamit szeretnék mondani, előbb jelentkezem.

5. Nem kiabálok, mindig nyugodtan és higgadtan beszélek.

6. Odafigyelek az órán. 
Környezete legyen rendezett, de rugalmas. Fontos, hogy pontos szabályokat építsünk ki, de úgy, hogy amellett elegendő mozgástere, szabadsága maradjon, ne érezze magát korlátozva. A szabályok legyenek határozottak, következetesek, kiszámíthatóak és egyértelmüek. A gyereknek tudnia kell, hogy tettei milyen következményekkel járnak, esetleges szabálysértés esetén. A szabályokon ne változtassunk, csak a gyerek fejlődésének megfelelően. Inkább kevesebb, határozott szabály legyen, mint sok, amit nem tart be.

Megbeszélhetünk saját, egyéni szabályokat is a gyerekkel. Ha bizonyos idő után ezeket nem szegi meg, jutalmazzuk meg érte. Segítsünk felismerni saját érzéseiket és megérteni mások érzéseit. Meg kell tanítani őket az önkontrollra. A feszültség levezetésére nagyon alkalmasak a légzőgyakorlatok, pl. „minden mély belégzéskor és kilégzéskor elszáll belőlem a feszültség". Ha nagyon ingerültnek látjuk a gyermeket, simogatással érdemes megnyugtatni és rövid, világos utasítást adni, pl. „úgy látom, szükséged van egy kis nyugalomra, nyugodtan menj hátra a pihenő sarokba és nézegess egy könyvet”. A tanítónak éreztetni kell a gyerekkel, hogy nem akarja ellenségként kezelni. Minél barátságosabb a viselkedésünk, sok-sok humort használva, annál nagyobb biztonságban érzi magát a gyerek, és jobban tudjuk a tanulásra motiválni. Ha ez sikerül, ezek a gyerekek talán még nagyobb szárnyat kapnak, mint társaik.

\section{Szervezetlen időbeosztás}

Nagyon rosszul viselik a gyerekek, ha valami elöre megbeszélt dolog változik, pl. esik az eső és nem mehetünk ki az udvarra, ilyenkor valami teret kell biztosítani, mozgási lehetőséget.

\section{Jutalom - büntetés}

Amikor sikerül változnia, bármilyen kis mértékben, azt azonnal meg kell erösíteni. Minden sikeres reakciót meg kell dicsérni, pl. „Tetszik nekem, milyen szépen jelentkeztél és csendesen vársz. Nagyon örülök, hogy sikerült megnyugodnod és készen vagy újra rám figyelni”. A hiperaktív gyerekeknél csak a jutalmazással érhetünk el hatást. Dicséret során az értékeléseinkbe mindig foglaljuk bele, hogy mi az, amit jónak látunk. Sokszor nincsenek tisztában azzal, hogy milyen az a jó viselkedés, szükségszerü, hogy konkrétan leszögezzük, mit is várunk el tőle. Ha rossz viselkedés felé tart a gyerek, minél hamarabb meg kell fékezni.

Nem szabad tehát megfeledkezni a jutalmazásról és a büntetésről. Csak az azonnali jutalmazás, ill. büntetés hatásos a hiperaktív gyerekeknél. Az ígéretekkel, fenyegetésekkel az ő esetükben nem megyünk semmire. Dorgálás esetén egyszer közöljük, hogy mi a büntetés, mert ha ismételjük magunkat, akkor a gyerek végül maga dönti el, hogy hányadszorra óhajt szót fogadni. Ha így nem érjük el célunkat, a következménynek azonnal kell történnie, különben nincs értelme. A büntetés nagyon nehéz a hiperaktív gyerekeknél, mivel nem úgy hat rájuk, mint az átlagos gyerekekre. Talán a leghatékonyabb, ha olyan tevékenységtől vonjuk meg őket, ami fontos számukra. Jutalmazni szintén azonnal kell, nem ígérgetni, mivel fontos számukra a sikerélmény, hogy tudják, jót cselekedtek, és ügyesek voltak. Az értékelés minden esetben a tetteikre vonatkozzon, ne a személyiségükre.

\section{Szabad mozgások beiktatása}

A hiperaktív gyerekeknek sokkal nagyobb a mozgásigényük, mint az átlagos társaiknak, ezért fontos mindig lehetőséget adni, ahol kiélhetik fokozott aktivitásukat. A mozgásos feladatok megvalósíthatóak az egész osztállyal, de szólhatnak csak neki is. Keressünk valami ürügyet, hogy elhagyja az osztálytermet, pl. küldjük őt el krétáért, töröltessük le vele a táblát stb.

Ezeknek a gyerekeknek a nevelését az ő sajátosságaikhoz kell alakítani, szeretik a mozgást, a teret, a változatosságot, az új dolgokat, ezért törekedni kell, az ilyen környezet létrehozására. 
Sokat segít, ha konkrét időbeosztásuk van, tehát mindig tájékoztassuk őket, hogy mikor mi fog történni. A feladatok nem szabad, hogy meghaladják képességeiket. Fontos a türelem, a megértés, és legfőképpen az odafigyelés, mert biztos, hogy azoknál a gyerekeknél, akik megkapják a kellö törődést, segítséget, csökkenthetők a negatív reakciók, ezáltal is könnyítve beilleszkedésüket.

\section{Zárógondolatok}

Tom Hartman „A figyelemzavar-szindróma másfajta megközelítése” címü könyvében úgy jellemzi őket, mint „vadászt a földmüvesek társadalmában (Neuhaus, 1997). A hiperaktív gyerek, vagyis a „vadász” mindig a környezetét fürkészi, amivel a figyelmének elterelhetőségét magyarázhatjuk. A vadász rugalmas, bevetésre kész, kedveli a kockázatot, amit tekinthetünk szervezetlenségnek, impulzivitásnak és a következmények figyelmen kívül hagyásának. Az „itt és most”-ban él, amit felfoghatunk türelmetlenségnek. A sztereotip módon rendszerességgel visszatérő dolgok untatják őt. Új ötletekre és lelkesedésre van szüksége, emiatt tartják álmodozónak. A lényegre tér, nem teketóriázik a szociális kommunikációval. Ezt pedig, mint a szociális érintkezési formák ismeretének hiányát róják fel neki.

A jó adottságok kihasználásával gyakran kiemelkedő eredményeket érnek el a társadalomban. Fantáziagazdagság, hajlékonyság, állandó érdeklődés, szokatlan asszociációs lépések, szokatlan ötletek, megfelelő motiváció esetén lenyügöző kitartás, ezek azok a tényezők, amelyek hozzásegítik őket a csúcsteljesítményhez. A saját érdeklödési köreiken belül és tehetségükhöz mérten többé-kevésbé mindegyikük „szenzációs”.

\section{Irodalom}

Conners, C. K. (1988). Conners' teacher's questionnaire. North Tonawanda, NY.: MultiHealth Systems Inch.

Franz, S. (1998). A hiperaktív gyerek. Budapest: Trivium Kiadó.

Gordon, T. (1994). Tanitsd gyermeked önfegyelemre. Budapest: Studium Effektive.

Goetz, M. és Uhlíková, P. (2010). ADHD Porucha pozornosti s hyperaktivitou. Praha: Galén s.r.o.

Jones, M. (2001). Hiperaktív gyermekek. Budapest: Édesvíz Kiadó,

Munden, A. \& Arcelus, J. (2006). Poruchy pozornosti a hyperaktivita. Praha: Portál.

Neuhaus, C. (1999). Hiper-és hipoaktivitás, figyelemzavar. Budapest: Kairosz kiadó.

Ranschburg J. (1998). Pszichológiai rendellenességek gyermekkorban. Budapest: Nemzeti Tankönyvkiadó.

Pokorná, V. (2001). Teória a náprava vývojových porúch učení a chovaní. Praha: Portál s.r.o.

Salló K. és Tóth J. (1995). Problémás a gyermek. Részképességzavarok kialakulása, felismerése, kezelése. Budapest: Littera Nova. 


\title{
NARRATÍV SZEMLÉLET A SEGÍTŐ KAPCSOLATBAN
}

\author{
Szerzők: \\ Bojti István \\ Integratív Medicina Kft. \\ Schéder Veronika \\ Debreceni Egyetem
}

\section{Lektorok:}

Madácsi Mária
Nyíregyházi Főiskola
Hüse Lajos
Debreceni Egyetem

Kondé Zoltánné Inántsy-Pap Judit

Debreceni Egyetem

Első szerző e-mail címe: ungvar35orvos@gmail.com
Koncz István

Professzorok az Európai Magyarországért Egyeület

Bojti István (2015): Narratív szemlélet a segítő kapcsolatban. Különleges Bánásmód, I. évf. 2015/2. szám, 59-70. DOI 10.18458/KB.2015.2.59

\begin{abstract}
Absztrakt
A szerzők a narratív szemléletben egy nagyon rugalmas gondolkodási keretet mutatnak be, ami nemcsak a segítö kapcsolatok széles skálájában, de akár a magánéletben is alkalmazható. Tárgyalják a narratív pszichológia alapját képezö posztmodernista és konstruktivista modellt. Három esetet használnak fel a módszer lehetöségeinek bemutatására. Az elsö esetben a viselkedés hátterében rejlö narratíva könnyen feltárható és egyszerü módon megváltoztatható, ezáltal a probléma megoldható. A második eset bonyolult problémát képez, és itt a narratív pszichoterápia eszközei kerülnek bemutatásra. Külön kiemeljük ebben a nyelvi eszközök tudatos felhasználását. A harmadik eset azt illusztrálja, hogy a problémák hátterében többféle narratíva lehetséges, és a megfelelö narratíva kiválasztása a megoldások lehetöségét is meghatározza. A narratívák választásakor a személy saját sorsát formálja meg, melyért felelösséggel tartozik.
\end{abstract}

Kulcsszavak: segítő kapcsolat, posztmodern, konstruktivizmus, narratíva, externalizálás

Diszciplina: pszichológia

\begin{abstract}
NARRATIVE APPROACH IN THE HELPING RELATIONSHIPS

The authors present a very flexible cogitative framework by using the narrative approach, which can be applied not only in a wide range of helping relationships, but also in private life. They discuss the postmodern and the constructivist model which form the basis for the narrative psychology. Three cases are presented to demonstrate the potential of the method. In the first case, the narrative behind the behaviour is easily detectable and can be altered in a simple manner, thus the problem can be solved. The second case encompasses a complex
\end{abstract}


problem, and the instruments of the narrative psychotherapy are presented here. The authors here emphasised the thoughtful use of linguistic instruments. The third case illustrates the possibility of multiple narratives for the underlying problems, and that choosing the right narrative determines the possibility for solutions. A person creates his/her own destiny when choosing the narratives, for which he/she bears the responsibility.

Keywords: helping relationship, postmodern, constructivism, narrative, externalization

Discipline: psychology

A társadalom gyorsuló ütemben változik. Az információtechnológia robbanása, a globalizált kultúra, a tekintély átalakulása, az egzisztenciális bizonytalanság, munkanélküliség, bevándorlók - olyan fogalmak, amikről egy emberöltővel ezelött alig hallottunk még. Hol van már a békebeli szexuálneurózis, amiből Freud felépítette a személyiségmodelljét? Ha a társadalom változik, a segítő kapcsolatnak is változnia kell. Vajon érvényesek-e a korábbi elméletek az új kihívások esetében? Hogyan lehet a segítőknek a rendkívül összetett új típusú problémákat követniük? Ma már nem a kliensek helyét kell az elméleti rendszerekben megtalálni, hanem az elméleteket kell a kliensekhez igazítani. Mindenki különleges bánásmódot igényel.

Terápiás gyakorlatunkban a posztmodern narratív pszichológia lehetőségeiben hatékony eszközöket találtunk, amelyekkel rugalmasan reagálhatunk a kliens problémájára.

\section{A posztmodernizmus}

A sokféleség kezeléséhez a posztmodernizmus megfelelő keretet jelent. Kialakulása a modernizmus elégtelenségére adott válasz volt.

A modernista gondolkodás a felvilágosodással kezdte diadalútját, az ipari forradalom, a napjainkban is tartó tudományos, technikai haladás hátterét adja. Alapszemlélete a megelöző korszak mitikus gondolkodásával szemben az, hogy a természet és a társadalom a maga teljes objektív valóságában megfelelő tudományos módszerekkel megismerhető, ez csak idő és források kérdése. Miután a valóság összes vonatkozása megismerszik, nyilván a helyes válaszok is megszületnek. A modernizmus az emberiség életminőségének korábban elképzelhetetlen javulásához vezetett (Wilber, 2009).

Bár a modernizmus alapvetése kétségtelenül logikus, egyre több viszonylatban derült ki, hogy mégsem érvényes. A fizikában a Heisenberg-féle bizonytalansági relációra, vagy a modellfüggő realitás elméletére utalok (Hawking és Mlodinov, 2011). Mindkét elmélet elvileg zárja ki a valóság objektív megismerhetőségét. A társadalomtudományok mindegyikéről elmondható az, hogy a kutatók hipotéziseit, a használt fogalmakat, módszereket a kutatók kulturális környezete meghatározza. Ezek a körülmények a kutatott jelenségnek általában nem részei, viszont a megállapításokban szükségszerüen visszaköszönnek (László, 2005). Az irodalomtudomány nagyon szépen fejezi ki a valóság variábilis jellegét, amikor azt állítja, hogy az irodalmi mü a befogadóban keletkezik (Bókay, 2006). Még a teológiában is találunk olyan állítást, hogy „Isten (...) ember elötti önmegnyilvánulása már függ attól, ahogyan az ember felfogja ezt a megnyilvánulást” (Tillich, 2002, 64. o.). A müvészi alkotásoknak pedig egyenesen fő témája éppen az a dráma, amit a valóság eltérő értelmezése jelent. Itt most kapcsolódóan csak Martin Scorsese Kazantzakis regénye alapján készült Krisztus utolsó megkísértése címü filmjére utalok. 
Mi adja a posztmodernizmus lényegét? A fenti példák mindegyikében közös az a tétel, hogy a valóság a maga objektív minőségében nem ismerhető meg. A megismerés aktusa maga befolyásolja a valóságot, valamint a megismerő szubjektuma befolyásolja a valóságról nyert mentális reprezentáció tartalmát (Goldenberg és Goldenberg, 2008). A posztmodernizmus tehát elutasítja azt a modernista állítást, hogy a valóság megfelelő módszerekkel teljesen megismerhető.

Ennek az alapállásnak több következménye van. Elöször is lemond a végső valóság megismerésének lehetőségéről, ami egyet jelent azzal, hogy elfogadja, hogy egymással párhuzamosan több, esetleg egymást kizáró valóságértelmezések érvényesek lehessenek. Mivel nincs egységes, mindenre érvényes elmélet, ezért a sokféleség természetes állapot, ami a sokféleség toleranciáját tételezi. A sokféle értelmezés jogossága bátorítja az egyéni szabadság nagyobb mértékü kiteljesítését. Ez az uralkodó felfogás kritikáját vonja maga után. A hagyományok háttérbe szorulnak, a nagyobb felelősség pedig előtérbe kerül.

\section{A narratív pszichológia}

A posztmodernizmus természetesen a pszichológiában is megjelent. Az egyik legismertebb ilyen rendszer a narratív pszichológia. A narratíva szó történetet jelent, egy nyelvi képződményt, alapjelentésében valamilyen időbeli eseménysor kezdettel, kibontakozással és befejezéssel (László, 2005). Például egy történet:

Amikor a szomszédomnak a karja zsibbadt, végül kiderült, hogy szívinfarktusa volt. Kórházban feküdt hetekig, megrokkanva jött haza és egy év múlva egy második infarktusban meg is halt.

A narratív pszichológia a történetet nemcsak egy konkrét eseménysorként, hanem ettől tágabban is értelmezi. A gondolkodásnak arra a sajátosságára utal, hogy a személynek a környezetére és a saját magára vonatkozó fontos tudása jellemzően történetekből eredeztethető. Ezek együttesen egy szubjektív élettapasztalattá állnak össze, mely a narratíva szó tágabb jelentése. Ebben az értelemben egy-egy narratíva formailag akár már nem is tekinthetö történetnek, hanem inkább valamilyen tapasztalaton alapuló vélekedésnek, vagy társadalmi normának, és a mögöttes konkrét történetek már homályba vesztek (Payne, 2014). A fenti példa mögött álló élettapasztalat narratívát a következőképpen lehet megfogalmazni:

Az ember életét mindenféle betegség veszélyezteti, jó lesz vigyázni.

Minden narratívára igaz, hogy a benne rejlö tudás eredete szubjektív, töredékes, valamilyen események személyes értelmezéséből származik. Minden narratíva lehetne más is. Ellentéte az „objektív” tudás, amely tudományos igényü vizsgálatok hozadéka (Payne, 2014).

Nemcsak az egyes egyének gondolkodása narratív jellegü, a különböző embercsoportoknak, a társadalomnak, egy-egy civilizációnak is vannak közös narratívái (erkölcs, értékek, szokások stb.). Ezeket a közös narratívákat diskurzusoknak is szokták nevezni, utalva csoportos jellegükre. Könnyen belátható, hogy a különböző narratívák hierarchiát alkotnak, illetve sok konfliktus értelmezhető a narratívák harcaként (Kecskeméti Molnár, 2004).

\section{A konstruktivizmus}

Annak érdekében, hogy az emberek biztonságosan eligazodjanak a világban, mindenki megpróbál a fontos tapasztalatainak valamilyen jelentést adni. Fontos körülmény, hogy a személy számára kevésbé az eredeti tapasztalat a lényeges, sokkal inkább az, hogy milyen jelentést tulajdonít neki (Goldenberg és Goldenberg, 2008). Például ha valakinek zsibbad a karja, egészen másként reagál akkor, ha azt fáradtságnak, mint ha szívinfarktusnak tulajdonítja. A valóságnak ez az értelmezése gyakran evidenciaérzéssel jár, holott pusztán egy mentális konstrukcióról van szó. Könnyü összetéveszteni a valóságot a róla alkotott 
konstrukcióval. Erre a helyzetre közismert a térkép és a táj metaforája (O'Connor és Seymour, 1996). A konstruktivista felfogás szerint a megismerés folyamatában a valóságról alkotott minden tudásunk csak konstrukció, ami töredékes, és biológiai, pszichológiai, kulturális hatások által befolyásolt.

A személyes és a társadalmi narratívák, valamint a tapasztalatokat értelmező konstrukciók között szoros összefüggés van. A narratívák együttese felfogható egy keretként, amelybe az egyén a konkrét tapasztalatait beilleszti, és a kerettel összhangban alkotja meg értelmező konstrukcióit. Természetesen párhuzamosan több különböző narratívát egyaránt érvényesnek tekinthetünk, amelyek ugyanazon valóság különböző konstrukcióihoz vezetnek (Payne, 2014).

Amennyiben a narratívákat az egyéni konstrukciók megalkotásának kereteként definiáljuk, úgy a nyelv nevezhető a konstrukciók hordozó közegének, „ruhájának”. Ahhoz, hogy a narratívák, illetőleg az értelmező konstrukciók kommunikálhatóvá váljanak, nyelvi jelleget kell ölteniük. A nyelvi rendszer keretei azonban mindig szegényebbek, szükebbek, avagy egyszerüen csak mások, mint a narratívákéi. Ez gyakori oka lehet a kommunikáció zavarainak a segítő kapcsolatokban. A segítő kapcsolatok csatornája ugyanis elsődlegesen a nyelvhasználat.

A szó, amely megnevez valamit, mindig három összetevő kapcsolata. Ez a három összetevő: a jelölő (azaz a hangalak), a jelölt (azaz a jeltárgy, a denotátum) és a beszélő/hallgató személye (Tolcsvai, 2002). A szavak elsődleges jelentését mindig a jelölő és a jelölt közötti közmegegyezésen alapuló kapcsolat adja. A jelölők és a jelentések közötti kapcsolat azonban többféle lehet. Szavaink többségének nem egy, hanem több jelentése is van. Előfordul, hogy ezek a különböző jelentések összefüggenek egymással (poliszémia), de az is lehet, hogy azonos alakhoz más-más jelentés társul (homonímia). A magyar anyanyelvüek ráadásul sokszor tulajdonítanak új jelentéseket egy-egy régi kifejezésnek - ez az egyik legtermékenyebb szóalkotási módunk. Ennek föként az az oka, hogy mindig több megneveznivalónk akad, mint ahány szó ezeknek a tartalmaknak a kifejezésére a rendelkezésünkre áll. A szó teljes, a beszélő és a hallgató számára értelmezett jelentésében ezen kívül egyéb jelentésfajták is megmutatkoznak. A konnotatív jelentés pl. a denotatívhoz valamilyen egyéni vagy közösségi értékrend/tudás alapján hozzárendelt képzettársításos jelentés: a csavar szó mást jelent egy müszerésznek, mást egy fodrásznak, egy jégtáncosnak stb. Az érzelmi jelentés a beszélő érzelmeit jelöli, ami leginkább a hangsúlyban, hanglejtésben, ill. a szóválasztásban mutatkozik meg (pl. ha azt mondom: Te csibész! - ebben az esetben a csibész szó használata részemröl kedveskedés).

A narratívák és konstrukciók megfelelő nyelvi formába öntése mind a kliens, mind a terapeuta számára bonyolult feladat, hiszen az érzelem maga, ami a narratívák és konstrukciók táptalaja, „túl van a szavakon”. A világot azonban az anyanyelveink által lefektetett irányvonalak mentén elemezzük - a közismert Sapir-Whorf hipotézis szerint a nyelv befolyással van arra, hogyan érzékelünk és emlékezünk, meghatározza a gondolkodásunkat (Crystal, 2003).

\section{A narratív gondolkodás a gyakorlatban}

A narratív szemléletű gondolkodás jellemzője tehát, hogy bár minden érintett tapasztalatainak a forrása azonos lehet, az eseményeknek mégis meglepően különböző jelentést tulajdoníthatnak. Ezért a segítö kapcsolatban különösen fontos, hogy a tapasztalatok személyes jelentését megismerjük.

A kliensek problémával kapcsolatos releváns történetei általában könnyen megismerhetőek, elég rákérdezni. Ezt követően a narratív szemléletü segítő kommunikáció a kliens narratíváját felhasználja az ellátás során, arra választ ad, hiszen a kliens elégedettsége alapvetően függ 
attól, hogy a saját problémájára választ kapott-e. Sok esetben valamilyen egyszerü intervencióval, például informálással, edukációval megnyugtató megoldás születik. A kommunikációnak ezt a formáját közvetlen vagy explicit kommunikációnak nevezzük (Schulz, 2012 - vö.: 1. esetbemutatás).

A narratívák más része azonban csak részben, vagy egyáltalán nem tudatosul a személyben, viszont annál nagyobb hatású a gondolkodására. A tapasztalatok széles körére kiterjed, a jelentésadó mentális folyamatokat konzekvensen valamilyen maladaptív irányba befolyásolja, egy beszükült világot teremt a kliens számára (Payne, 2014). Ezeket a narratívákat nemcsak azonosítani nehéz, de a megváltoztatásuk is erőfeszítést igényel. Az edukáció általában nem elegendő. Az ilyen narratívák tehát csak implicit módon jelennek meg a kommunikációban, észlelésük és értelmezésük a segítőtől többszempontú elemzést kíván.

Ezek a kliens gondolkodását alapvetően befolyásoló narratívák, amelyek már a tudatos gondolkodás határain kívülre kerültek, önálló tudattartalom entitásukat elveszítették. Azaz a személy ezeket egy érzelmi beállítódásnak, a gondolkodás alaptónusának érzékelné, ha a figyelmét erre irányítaná. A narratíva határai sem érzékelhetőek, mindent áthat. Nem is nyelvi karakterü ez a tudattartalom, mert nem lehet megnevezni, a hatása pedig nem szavakban érvényesül. A fenti karzsibbadással kapcsolatos eset példájában ezt valamilyen lebegö félelemnek, a testi érzésektől való riadalomnak próbálhatjuk meg leírni.

A narratívának ez a minősége érthetővé teszi, hogy a szokásos gondolkodás számára megfoghatatlan, így kezelhetetlen. A logikus érvelés hatástalan rá. A tapasztalatok igen nehezen befolyásolják, hiszen nem a tapasztalatok vannak a narratívára hatással, hanem fordítva, a narratíva adja meg a tapasztalatok jelentését. A merev, maladaptív viselkedés hátterét ez a modell értelmezhetővé teszi (2. esetbemutatás).

A narratív szemléletü intervenció meghatározó mozzanata az, hogy a fenti diffúz lelki tartalmat a nyelv segítségével azonosítjuk, más lelki tartalmaktól elhatároljuk. Ez a gyakorlatban azt jelenti, hogy a kliens bizonyos tulajdonságait, késztetéseit, gondolatait hozzárendeljük, és névvel látjuk el. Fontos, hogy a segítő saját nyelvhasználatát a klienshez igazítsa. J. L. Austin az ún. beszédaktus-elméletben fogalmazta meg elöször azt, hogy egyes megnyilatkozások nem csupán információt közvetítenek, hanem cselekvésértékük van. Az ilyen típusú közlések valamilyen új pszichológiai vagy társadalmi realitást eredményeznek (Crystal, 2003). A névadással egy, a kliens tapasztalataival koherens új entitás jön létre, a szavak valami fontos újat teremtettek. Korábbi esetünket követve az új entitásnak lehetne a neve Félelem. Félelem fő üzenete az, hogy az élet fenyegető, Te esendő vagy, és bármikor baj érhet. Ez az új entitás a hétköznapi gondolkodás számára könnyebben kezelhető. Plasztikus metaforája lehet egy személyiségrész. Tovább segíti az új entitással való munkát az, hogy a szándékai, a hatásmódja, a története a kliens számára énközeli, hiszen minden mozzanatban a saját lelki tartalmaiból építkeztünk. Nem utolsósorban az új entitás elkülönül az egyéntől, mintegy külsővé lesz, és bünbakká válhat. Azaz elhordozza a problémákért a felelösséget. Ezért az intervenció elterjedt elnevezése az externalizáció. Nem az ember a probléma, hanem a probléma a probléma (Kecskeméti Molnár, 2004). Ez a hatás a felelősség szempontjából körültekintést igényel a segítő részéröl, de a büntudat által bénított depressziós kliensek esetében nagyon pozitív lehet.

A segítő folyamat további részében ez a korábban beazonosíthatatlan és elérhetetlen tudattartalom externalizálva a gondolkodás reflektorfényébe kerül. Részletes elemzésnek, értelmezésnek vethető alá, melynek során az evidens állítások megkérdőjeleződnek, ellentmondásosságuk kiderül, a részletező perspektívában differenciálódnak, azaz dekonstruálódnak. Az új alternatívák kidolgozása és kipróbálása a rekonstrukció folyamata, aminek során átalakul egy remélhetőleg adaptív viselkedés motivációjává (Prochaska és Norcross, 2011). 
Külön kiemelést érdemel, hogy a személy a narratívák révén nemcsak jelentést ad a tapasztalatainak, hanem az adott jelentés alapján alakítja is a viselkedését. Végeredményben tehát a narratívák a jövőre is irányulnak, és teremtik a valóságot. Tekintettel arra, hogy mindenkinek van valamilyen mértékü választási lehetősége arra, hogy milyen narratívákat alkosson a világról, végeredményben így mindenki alkotója a saját világának. A szabadság felelősséggel jár (Yalom, 1978). Lehetőleg előrevivő narratívákat kellene alkotni, amelyek jó programot kínálnak a probléma meghaladásához. A problémákkal küzdő személyek narratívái ezzel szemben tehetetlenséget sugallnak (3. esetbemutatás).

\section{A segítő narratívái}

A narratív szemlélet sajátossága, hogy nemcsak a kliens, hanem a segítő narratíváit is tekintetbe veszi. Bár magától értetődik, hogy a segítő lelki munkamódja alapjaiban megegyezik a kliensével, a segítő önreflexiója mégis gyakran háttérbe szorul, ezért különös figyelmet igényel. A szimmetrikus alapállásból következik, hogy a narratív szemléletü segítő kapcsolat nem az alá-fölérendeltséget hangsúlyozza, hanem a klienst a saját élete, a segítőt pedig a saját szakmája szakemberének tartja. Ennek a kétfajta mellérendelt szakértelemnek az együttműködésétől várja a probléma megoldását.

A segítő releváns narratívái számos témában jelenhetnek meg, mellyel Bálint Mihály részletesen foglalkozott az orvos apostoli funkciója fogalom megalkotásakor és elemzésekor (Bálint, 1990). Csak néhány fontosabbat említünk meg az alábbiakban:

A személyes szakmai tapasztalatok nyilvánvaló értéket jelentenek. Ezek a tapasztalatok a narratívák olyan együttesét jelentik, amik a segítő látásmódját döntően befolyásolják. Ebből eredően azonban fennállhat a veszélye az elöítéletességnek, a sematikus, redukcionista problémakezelésnek.

A segítök képzésük során különféle szakmai elméleteket tanulnak meg, melyek a problémákat kategorizálják, értelmezik, prognosztizálnak, és a kezelés módját lefektetik. Az ember hajlamos e tekintélyszemélyek által is bebetonozott tételekre evidenciaként tekinteni, pedig mindegyik elmélet csak egy modell, korlátozott érvényességi tartománnyal. Egy konstrukció, nem pedig maga a valóságos folyamat.

Ugyancsak fontosak azok a narratívák, amik a társadalom szokásos gyakorlatára vonatkoznak, és ezekkel könnyü a segítőnek azonosulni. Például hagyományok, etikai álláspontok, viselkedési szabályok tartoznak ide.

Tágan értelmezve a segítő munkahelyének is vannak közös narratívái, melyben a dolgozók osztoznak. Például a munkamegosztás, a konzultáció szabályai, a segítő kapcsolat helyi értelmezése és egyéb szokások. Ezek a segítő munkának nagyon fontos keretfeltételei, amikre adottságként szoktunk tekinteni. Holott csupán egy csoport konstrukciói, és minden eleme másképp is lehetne.

Az előzőekben a segítő munka olyan szilárd alapvetéseit kérdőjeleztük meg, mint a személyes szakmai tapasztalatok, az elméleti megalapozás, a kulturális feltételek, a munkahelyi kultúra. Mindezeket a valóság érvényes leírása helyett csak konstrukcióknak tekintjük, ugyanúgy, mint a kliensek narratíváit. Milyen nyereség származik ebböl? Egy szélsőséges relativizmus inkább bénító hatású lehet.

Elöször is, bár a narratív szemlélet elismeri, hogy minden lehetne másként is, ez nem jelenti azt, hogy ne lennének sokszorosan bevált jó konstrukciók, amikhez érdemes ragaszkodni. Csak annyit jelent, hogy a segítő nyitott arra, hogy ezeket a konstrukciókat felülvizsgálja. Ezzel nagy felelősséget vállal, hiszen biztonságosabb a hagyományokhoz igazodni, mint azokat mérlegelni. 
A saját beállítódások narratívaként észlelése a segítőt rugalmassá teszi, a klienshez jobban tud alkalmazkodni. A rugalmasságból ered, hogy kevesebb konfliktussal találkozik, ezért kisebb a kiégés veszélye.

A posztmodernizmus hozadéka az a felismerés, hogy a segítő sohasem ismerheti meg a klienst és környezetét a maga valóságában, azért, mert ebben puszta jelenlétével változást idéz elő és a részévé válik. Tehát az a karteziánus beállítódás, hogy a külsős szakember megvizsgálja a helyzetet, megérti, majd a megoldást kigondolja és megtanítja a klienssel, ebben a keretben nem lehet érvényes. Ehelyett a segítő folyamatot a segítő és a kliens narratíváinak egyeztetéseként, kölcsönös egymásra hatásaként, a közös narratíva megtalálásaként értelmezi (Launer, 2002). E szemlélet talán segít abban, hogy az esetek növekvő hányadában sikerüljön a problémákra kielégítő megoldást találni.

\section{1. esetbemutatás}

Az 5 éves Noémi szülei válását követően enurezis tüneteivel lovasterápiás kezelésben részesült. 3 hónap után tünetmentesen hagyta el a terápiát (ezalatt heti 1 alkalommal 30 perces foglalkozásokon vett részt), de újabb fél év elteltével visszaesett. Édesanyja szerény, kicsit szorongó alkatú asszony, lánya a kisebbik gyermeke. A lovasterápiás foglalkozásokon korábban nagyon jó kapcsolatunk alakult ki, nemcsak Noémivel, hanem az édesanyjával is. Rendszeresen utolsóként jöttek, a ló gondozására még ottmaradtak, és olyankor fontos dolgokról beszélgettünk. Az újabb terápia csak néhány hétig tartott, eredményesnek látszott és a befejezését terveztük. Érezhető volt, hogy az édesanyát valamiért aggasztja a terápia közeli befejezése. Új problémát hozott szóba, és a tervezett utolsó órára Noémi visszaesett. Rákérdeztünk a félelmeire. Kiderült, hogy egyrészt attól tart, hogy a lovasterápiás kezelések nélkül a kislány tünetei újra jelentkezni fognak (ami immár be is következett), és ezt az állapotot egyedül nem fogja tudni kezelni. Másrészt bevallottan neki magának is nagyon sokat jelentettek ezek a foglalkozások, a tartalmas közös beszélgetéseink, és most ezt is elveszni látja.

Átéreztük a félelmeit. Megerősítettuik az édesanyát, hogy nekünk is fontos volt a közöttünk kialakult kapcsolat, és nem ragaszkodunk ahhoz, hogy hirtelen megszakítsuk. Megállapodtunk abban, hogy 3 hetente még továbbra is fogunk találkozni, annyi alkalommal, ahányszor ezt ő szükségesnek tartja. Ha Noémi tünetei kiújulnának, akkor várhatóan azok már csak hamar múló panaszok lesznek. (Példaként hoztuk fel a korábban is megtapasztalt sikereket, nem pedig a kudarcokat.) Láthatóan mindenki elégedett volt ezzel a megállapodással, és megkönnyebbülve váltunk el egymástól.

Összesen kétszer jöttek még el, több találkozást nem igényeltek. A bemutatott esetben az édesanya és a lánya a terápia végére szorongóvá vált. Ezt burkoltan fejezték ki: Noémi visszaesett, édesanyja új problémákkal hozakodott elő. Gyanítható volt, hogy a háttérben valamilyen félelem húzódhat meg. Az aggodalmat kiváltó narratívájuk könnyen kiderült, elég volt rákérdezni, hogy mitöl tartanak: egy sikeres kezelés után is könnyen visszaesés következhet be (ez éppen megtörtént), és az édesanya a támaszát érezte elveszíteni. Csak feltételezhetjük, hogy az intervenciónk melyik eleme járult hozzá az elválási probléma sikeres megoldásához.

Először is szóba jöhet az, hogy a kimondatlan félelmetes narratíva nyílt megfogalmazása önmagában is fontos volt. A terápiás kapcsolatot mélyítette.

Másrészt a narratíva lényegére adekvát megoldást ajánlottunk: nem kell elválnunk egymástól, a találkozások számát édesanya kontrollálhatja - bár nem hetente, hanem 3 hetente.

Noémi prognózisát tudatosan a pozitív tapasztalatok folytatásaként alkottuk meg, számítva ennek szuggesztív hatására. Azt akartuk elérni, hogy egy esetleges visszaeséshez az anya ne katasztrofizáló jelentést konstruáljon. 
Az esettel azt kívántuk szemléltetni, hogy sok probléma hátterében a kliens egy kimondatlan narratívája lehet. Ezt gyakran egyszerü módon is fel lehet tárni, és megnyugtató választ találva a probléma megoldható.

\section{2. esetbemutatás}

A klienssel egyéni pszichoterápiás helyzetben találkoztunk. Az eset bemutatásakor a terapeuta és a kliens narratíváira és az externalizációra fókuszálunk.

Egy 36 éves férfi azért keresett meg, mert először 3 hónapja, majd egyre gyakrabban gyors szívveréssel, remegéssel, szédüléssel, zsibbadással, halálfélelemmel járó rohamszerü rosszullétei voltak. Amikor nem volt rohama, akkor attól félt, hogy mikor lesz a következö. Emiatt a vállalkozását csak nagy szenvedés árán tudta felügyelni, emiatt anyagi hátrány is érte már. A szülei és a felesége segítökészen és türelmesen viselték a betegség következményeit. Az élettörténetéből még kiderült, hogy 8 éve folytatta a jelenlegi kereskedelmi vállalkozását, ami nagyon kimerítette. Évek óta nem volt szabadságon, gyakran csak 3-4 órát aludt, fizetési nehézségei voltak, elhúzódó konfliktusa volt a hatóságokkal. Több orvosi vizsgálaton volt túl, mire terápiába jelentkezett. Ezek a vizsgálatok kicsit ingadozó vérnyomást igazoltak, ami azonban a panaszával nem volt összefüggésbe hozható. Más tekintetben szervi eltérés nem volt kimutatható. Pánikbetegséget állapítottak meg, és háziorvosa küldte pszichoterápiára.

A terapeuta narratívái: tapasztalataink alapján a bármilyen ok miatt túlhajszolt, arányaiban felborult életmód vezethet hasonló tünetekhez. A rövid kórtörténet, rendezett család, anyagiak és a betegség előtti jó teljesítmény alapján jó prognózisra, rövid terápiára számítottunk. A terápiás módszer választása kérdésében modernista szemléletet nem akartunk alkalmazni, mert úgy éreztük, hogy ha valamilyen kész elméleti modellbe próbáljuk kliensünk történetét beilleszteni, akkor lehet, hogy a számára legfontosabb dolgoktól eltérítjük a terápiás folyamatot. Ez időveszteség lenne és nem szolgálja a terápiás kapcsolatunkat. Tovább figyeltünk, és rákérdeztünk a saját narratívájára.

A kliens narratívája: számára a fő problémát a pánikbetegség tünetei jelentették. Ha nem lett volna a betegség, folytatta volna a munkáját, úgy és ahol abbahagyta. Mivel beteg volt, ezért nem tudott dolgozni, a problémák csak nőttek, egyre kevésbé látta a betegsége végét, és még betegebb lett emiatt. Ebböl az ördögi körből nem tudott kilépni. Jól érzékelhető a maladaptív narratívákra jellemző kilátástalanság.

Mivel az elsődleges panasza a pánikbetegség volt, a szorongás mögött húzódó halálfélelem egzisztencialista narratíváját beszéltük meg, és kitértünk a halálfélelem csökkentésére szolgáló stratégiákra is. Néhány viselkedésterápiás szorongásoldó manőverre (légzéskontroll, figyelemkontroll) is megtanítottuk, és kilátásba helyeztük a betegsége jó prognózisát. Gyógyszeres kezelést nem igényelt.

A következő alkalommal a szorongás gyengüléséröl számolt be. Ebben visszamenőleg jelentősnek ítélte meg a jó prognózisra vonatkozó megjegyzésünket, valamint a halálfélelmet is a beszélgetés után távolságtartóbban tudta szemlélni. Ez a változás lehetővé tette, hogy kevésbé a tüneteivel foglalkozzunk, hanem további részleteket, érzelmeket ismerjünk meg az életéből. Szerettük volna megfigyelni, hogy milyen meghatározó narratívák vannak a fö életproblémák hátterében. Kiderült, hogy ez a vállalkozás túl nagy terhet jelentett számára. Mostanáig megoldott mindent, de túlságosan stresszelt. Nem szeretett a partnerekkel érintkezni, a hatósági vizsgálatoktól pedig egyenesen rettegett. Viszont abbahagyni sem lehetett, mert tisztességes megélhetést biztosított, és a család már hozzászokott a magasabb életszínvonalhoz. Korábban tanár volt, előrelépésnek tartotta a vállalkozást. A származási családját is ez a feltörekvő szellem hatotta át. Szülei másodállásban gazdálkodtak, öccse vállalkozó háziorvos volt.

A terapeuta narratívája a következőképpen alakult: tehát a kliens a feltörekvő családja narratíváját vallotta magáénak, miszerint a szorgalom, munka, gyarapodás az érték, és ennek 
alá kell rendelni a nyugalmat, arányosságot. Láthatóan a klienst ez nyomasztotta, de nem volt bátorsága szembefordulni ezzel a mélyen a nyugati civilizációban gyökerező domináns narratívával. Az alternatív emberközelibb narratíva alárendelt pozícióban volt, meg sem merte fogalmazni. A terapeuták a helyzetet a domináns narratíva elnyomó hatásaként értelmezték, melynek szükségességét megkérdőjelezhetőnek tartották.

A másik alternatíva lehetett volna az, hogy a kliens megtartja a feltörekvő narratívát, és emellett a terapeuták megtaníthatták volna konfliktuskezelésre, a vállalkozás szerkezetében strukturális változtatásokat beszélhettek volna meg, esetleg még elmehetett volna a kliens valamilyen menedzserképzésre. Várhatóan így kisebb megterhelést jelentett volna a cég vezetése.

Tekintettel arra, hogy a két alternatíva közötti választás a terápia és a beteg sorsának is egy fordulópontja, a terapeuták nem dönthettek, hanem ezt a dilemmát megbeszélték a beteggel. Ö pedig már annyira kiégett a vállalkozásban, hogy az első opciót, a domináns narratíva vizsgálatát választotta.

A domináns narratíva dekonstrukciójának első lépése az externalizálás volt:

Ahogyan figyeljük Önt, amikor a vállalkozásának nehézségeiről beszél, az az érzésünk, hogy az Ön lelkének egy része folyamatosan és kíméletlenül arra kényszeríti Önt, hogy csak csinálja, eröltesse, nem számít, mibe kerül, a vállalkozásának termelnie kell. Mi a véleménye, hogy pontosan látjuk-e ezt mi?

Ebben a mondatban láthatóan egymásra találtunk a klienssel, lelkesen megerősített, hogy igen, pontosan így érzi. Megkértük, hogy adjon a lelke ezen részének egy nevet, hogy tudjunk róla beszélni. A „Törekvés” nevet adta neki. Ettől kezdve minden lehetséges alkalommal a mondat alanya Törekvés volt. Például Törekvés nem hagyta elaludni, amikor túl sokáig dolgozott éjszaka. A házi feladata is az volt, hogy Törekvés hangját vegye észre a gondolataiban, és írja le, ügyelve Törekvés alanyiságára.

A későbbi beszélgetések alatt a Törekvés sugallta gondolatok és cselekedetek beazonosítása után Törekvés kialakulásának körülményeiről beszélgettünk, Törekvés céljáról, pozitív hatásáról, és arról, hogy mibe került Törekvés - a kliensnek és másoknak. Eljutottunk oda, hogy Törekvés eszköz helyett életcél lett, a kontroll alól kiszabadult, mint egy hajóágyú. Innen már magától következett, hogy Törekvés helyett milyen életcélokról tud gondolkodni, és ehhez milyen feltételeket kell megteremtenie, milyen áron.

Közben a szorongásos tünetek háttérbe szorultak, el is felejtkezett róluk.

A kliens úgy döntött, hogy a vállalkozását értékesíteni fogja, és állást fog keresni.

Ebben az esetleírásban a kliens pánikbetegség tüneteivel jelentkezett, melyet egy kulturálisan mélyen megalapozott feltörekvési narratíva által keltett feszültség következményének minősítettünk. Bemutattuk az externalizáció technikáját, a kliens és a terapeuta narratíváinak kölcsönhatását, a dialektikus fejlödésük folyamatát, melynek eredményeként végül elkészült a közös narratívájuk.

\section{3. esetbemutatás}

Párterápiás kontextusban történt az eset, és a narratívák kiválasztásának felelősségéről szól.

Egy negyvenes éveiben járó házaspár jelentkezett terápiába a feleség házasságon kívüli szerelmi kapcsolata miatt. A pár mindkét tagja diplomás volt, munkahelyükön vezetö beosztást töltöttek be. A munkahely sok idejüket és energiájukat igénybe vette. Két alsó tagozatos gyermekük volt. Az utóbbi években a kapcsolatuk elszürkült, kölcsönösen elhanyagolták egymást, a munka és a gyermekek gondozása töltötte ki az idejüket. A szexuális életük is ellaposodott. Az asszony az új párkapcsolatban megtalálta a boldogságát. Azonban nagy válságba került mindenki, amikor lelepleződött a viszonyuk, és a férje mindent megtett azért, hogy visszaszerezze a feleségét. A terápia során eldőlt, hogy az asszony a családját választja és megszakítja a házasságon kívüli kapcsolatát. A döntést közvetlenül 
követően kapcsolódunk be a terápiába, amikor még a „hogyan tovább” kérdése függőben van. Így még meg kell találniuk az új életük szabályait, megoldást kell találniuk a büntudatra és a megbocsátásra.

A házaspár mindkét tagját megkértük, hogy mondják el, hogyan értelmezik a történteket.

A kérdés jelentése az volt, hogy készítsék el a krízisük narratíváját, azaz adjanak magyarázatot arra, hogy mi miért történt. Ez a jelentésadás nagy fontosságú volt a jövőre nézve. Nézzünk meg több lehetséges narratívát:

1. Az asszony csapodár természetü, nem tud ellenállni a kísértésnek.

2. A férj alulmaradt riválisával szemben.

3. Egy húsz éves házasság már érzelem nélküli, kiég, gyakran így ér véget másutt is.

4. A kölcsönös érzelmi elhanyagolás vezetett a hütlenséghez, és a külső kapcsolat nyújtott kárpótlást. De a család ereje visszafordította a folyamatot.

Abból a szempontból vizsgáljuk meg a lehetséges narratívákat, hogy milyen utakat nyitnak meg a jövőre nézve!

1. Az asszony csapodár természetével nem lehetett volna mit kezdeni, hacsak nem egy elhúzódó féltékenységi stratégia kidolgozását. Ez nagyon hátrányos lett volna a jövőre nézve.

2. Ha a férj alulmaradt, akkor abból kisebbségi érzés és féltékenység, gyötrődés következik. Kétséges kimenetelü lett volna a férj önbizalmának erősítése. Ez is borús perspektíva.

3. A húsz éves házasság menetrendszerü kiégése szinte normává teszi a hütlenséget és a válást, felmenti a felelősség alól a szereplöket. Sodródást jelent a válás felé.

4. Ha a kölcsönös elhanyagolás következményének tartjuk a krízishelyzetüket, akkor ebböl következik egy program, hogy hogyan ne hanyagolják el egymást a jövöben. Ha a család erejének tulajdonítjuk a folyamat visszafordítását, akkor ezzel a férjet elsősorban, de a feleséget is megerősítjük, hiszen olyan emberekként tünnek föl, akik képesek a családjukért egy ilyen gödörből felküzdeni magukat. Egyúttal a büntudat és a megbocsátás felé is teszünk egy lépést, azáltal, hogy a krízis után jobb lesz a kapcsolatuk, mint előtte volt. Egy végeredményében pozitív hatású cselekedetért miért kellene megbocsátani, illetve büntudatnak lenni? Ez persze nem ilyen egyszerü, lehet ok a büntudatra, de ez a narratíva mindenképpen könnyíti a megbocsátás és a büntudat feldolgozását is.

Az eset követését itt nem folytatjuk, mert csak a narratívák fontosságát akartuk demonstrálni. Lépjük át a párterápia kontextusát, mert az eset tanulságai minden segítő kapcsolatban, sőt a magánéletben is érvényesek.

Láthatóan több lehetséges alternatív értelmezés is szóba jöhet, bár erre a gyakorlatban nem mindig gondolunk. Nagy felelösség, hogy az érintett személy átgondolja a lehetséges értelmezéseket és megfelelően válasszon. A fenti példákból az következik, hogy az a jó narratíva, amelyik valamilyen járható utat kínál a megoldás felé. Amelyik előrevisz. Aki azokat a narratívákat választja, amelyek nem kínálnak megoldásokat, felelőssé válik a saját kudarcaiért.

Felmerül az a kérdés, hogy bár nyilván számít, hogy milyen megoldásokat kínál egy narratíva, de melyik narratíva az igaz? Ebben a helyzetben az igazság nem látszik egy jól használható fogalomnak több szempontból sem. Először is ritkán fordul az elö, hogy egy fontos döntésnek egyetlen magyarázata lenne. Az „,igazság” tehát az okok között egy százalékos megoszlás lenne.

Másrészt kérdéses az is, hogy a több szereplő közül kinek az ,igazságáról” beszélünk? Kinek-kinek az események során változik a személyisége, és korábbi véleményét már saját 
maga is érthetetlennek tartja. Akkor ilyen esetben melyik időpontban érvényes „,igazságát” vesszük tekintetbe?

Ha a megoldás érdekében a felek úgy döntenek, hogy függetlenül a ,igazságtól” egy előrevivő értelmezést választanak, akkor az a narratíva meg fogja határozni a tetteiket és valósággá válik. Az eredeti ,igazságuk” csak egy lépcsőfoknak nevezhető, mely a megoldáshoz vezetett.

Természetesen a narratív szemlélet alapján sem lehet a múltat meg nem történtté tenni, a felelősséget elkenni, de a megoldás felé mutató narratívákat lehet mérlegelni.

A segítő helyzetben a terapeuta felelősséget vállalhat abban, hogy a kliensekben a narratívák közötti választás lehetőségét tudatosítsa.

\section{Konklúziók}

A gyorsan változó társadalomhoz a segítő kapcsolatnak is alkalmazkodnia kell. A posztmodern narratív szemlélet sok vonása mutat ebbe az irányba. A valóság mentális reprezentációját szubjektív konstrukcióknak tartja, ugyanígy a társadalom domináló diskurzusait, például az értékrendet, a divatot, a hagyományokat is. A konstrukciós jelleg lényegéből fakad, hogy mindezek megkérdőjelezhetőek, bár az emberek ezeket jellemzően evidenciaként élik meg. A narratív szemlélet a konstrukciók átalakíthatóságában látja a beavatkozás lehetöségét.

A legegyszerübb narratívák könnyen kommunikálhatók, megválaszolhatók, lezárhatók, ha gondolunk rá. A mélyen gyökerező, csak részben tudatos narratívák már nagyobb erőfeszítés révén, a nyelv lehetőségeit felhasználva dekonstruálhatók.

A narratív szemléletű segítő intervenciók viszonylagos gyorsaságát és rugalmasságát az adja, hogy szorosan a kliens aktuális problémájához illeszkednek, személyre szabottak. Újszerü vonásuk, hogy a segítőt partneri szerepbe helyezik, akinek a saját narratíváival ugyanúgy feladata van, mint a klienséivel.

Tekintettel arra, hogy a szemlélet a valóság sokféle értelmezésének szabadságát támogatja, különösen fontos mind a kliensnek, mind a segítöjének a saját és a mások sorsáért viselt fokozott felelösséget észben tartania.

\section{Irodalom}

Bálint, M. (1990). Az orvos, a betege és a betegség. Budapest: Animula Egyesület.

Bókay, A. (2006). Bevezetés az irodalomtudományba. Budapest: Osiris Kiadó.

Crystal, D. (2003). A nyelv enciklopédiája. Budapest: Osiris Kiadó.

Goldenberg, H. és Goldenberg, I. (2008). Áttekintés a családról. Budapest: Animula Kiadó.

Hawking, S. és Mlodinov, L. (2011). A nagy terv Budapest: Akkord Kiadó.

Kecskeméti Molnár, M. (2004). Narratív terápia * bemutató és ajánlás Új-Zélandból. Pszichoterápia, 13, 366-376.

László, J. (2005). A történetek tudománya. Budapest: Új Mandátum Könyvkiadó.

Launer, J. (2002). Narrative-based Primary Care. Abingdon, Egyesült Királyság: Radcliffe Medical Press.

O’Connor, J. és Seymour, J. (1996). NLP. Piliscsaba: Bioenergetic Kft.

Payne, M. (2014). Narratív terápia. Budapest: Magyar Családterápiás Egyesület.

Prochaska, J. O. és Norcross J. C. (2011). A pszichoterápia rendszerei. Budapest: Animula Kiadó.

Schulz von Thun, F. (2012). A kommunikáció zavarai és feloldásuk. Budapest: Háttér Kiadó. Tillich, P. (2002). Rendszeres teológia. Budapest: Osiris Kiadó. 
Tolcsvai Nagy, G. (2002). Szójelentés. In Sipos, L. (szerk.), A magyar nyelv és irodalom enciklopédiája (pp. 112-115) Budapest: Magyar Könyvklub.

Wilber, K. (2009). A müködő szellem rövid története Budapest: Ursus Libris Bt.

Yalom, I.D. (1978). Egzisztenciális pszichoterápia. Budapest: Animula Kiadó. 


\title{
A DINAMIKUS SZENZOROS INTEGRÁCIÓS TERÁPIA (DSZIT) A VERBÁLIS KOMMUNIKÁCIÓS ZAVAROK REHABILITÁCIÓJÁBAN
}

\author{
Szerző: \\ Szabó Edina \\ Debreceni Egyetem \\ Szerző e-mail címe: \\ szedina5@ hotmail.com
}

\section{Lektorok:}

Szilágyi Barnabás

Debreceni Egyetem

Schéder Veronika

Debreceni Egyetem

Mező Katalin

Debreceni Egyetem

Mező Ferenc

Debreceni Egyetem

Szabó Edina (2015): A dinamikus szenzoros integrációs terápia (DSZIT) a verbális kommunikációs zavarok rehabilitációjában. Különleges Bánásmód, I. évf. 2015/2. szám, 7180. DOI 10.18458/KB.2015.2.71

\begin{abstract}
Absztrakt
A tanulmány bemutatja a DSZIT (Dinamikus Szenzoros Integrációs Terápia) alkalmazhatóságát a felnött stroke betegek logopédiai rehabilitációjában. Rávilágít azokra a viselkedési, kommunikációs zavarokra, amelyek jelenléte utal szenzoros integrációs eltérésre, vagyis indikálhatja a terápia felajánlását a páciensnek.
\end{abstract}

Kulcsszavak: szenzoros integrációs terápia, rehabilitáció, kommunikáció

Diszciplína: gyógypedagógia

\begin{abstract}
DYNAMIC SENSORY INTEGRATION THERAPY (DSZIT) IN REHABILITATION OF VERBAL COMMUNICATION DISORDERS

The study presents the DSIT (Dynamic Sensory Integration Therapy) and its applicability to adult stroke patients with speech therapy rehabilitation. It explains the kinds of behavioral and communication disorders, which may mean the presence of sensory integration disorganisation, so may indicate offering the therapy to the patient.
\end{abstract}

Keywords: sensory integration therapy, rehabilitation, communication

Disciplines: special education 
Dr. A. Jean Ayres 1960-ban javaslatot tett a foglalkozásterápia területének kiterjesztésére az érintett személyek motorikus zavarainak a kezelésre vonatkozóan (Spitzer és társai, 1996). A munkája kiterjedt a tervszerü mozgásos gyakorlatok alkalmazására, a szenzoros stimuláció, az érzelmek, a viselkedés befolyásolása érdekében, illetve, hogy a kezelt személy belső erőtől vezérelve dolgozzon a saját idegrendszere fejlődésén.

A szenzoros integráció egy lehetőség a viselkedés leírására, magyarázatot adhat bizonyos viselkedési eltérésekre. Segít megérteni például, hogy egyes személyek miért viselkednek és reagálnak bizonyos módon, miért zavar embereket a ruhák belsejében található címke, miért nem akar megenni bizonyos konzisztenciájú ételeket, és miért képtelen egy emberektől zsúfolt helyen lenni. A szenzoros integrációs teóriák segítenek leírni az agy-viselkedés kapcsolatát, választ adnak például arra, hogy a motoros tervezési képesség hogyan függ össze a taktilis-kinesztetikus információk adekvát feldolgozásával. A beérkező információk feldolgozása segíti az agy fejlödését, illetve egy belső modell leképezését önmagunkról. A hipotézis szerint a taktilis-kinesztetikus információk adekvát feldolgozási képességének a sérülése eredményeképpen a motoros tervezés zavara (vagyis a diszpraxia, apraxia) áll fenn, amely a beszédprodukcióban is hozza a tüneteit.

A Dinamikus Szenzoros Integrációs Terápia (DSZIT) ismert eljárás gyermekek tanulási, figyelmi, magatartási eltéréseinek kezelésében, de egyre több tudományos bizonyíték van arra vonatkozóan is, hogy a felnőtt populáció rehabilitációjában is hatékony kezelési forma lehet (]ongbloed, Stacey, és Brighton, 1989)

A beszámolók szerint elsőként pszichiátriai alkalmazásban jelent meg, skizofréniában szenvedő beteg kezelésénél (King, 1974). Továbbá találunk adatot katonák tanulási zavarainak szenzoros integrációs terápiás kezeléséről (Riggan, 1983). Geriátriai alkalmazásról (Breines, 1988, Gielow, Hobler, 1986, Ross és Burdyck, 1981). Illetve koponyatrauma és stroke kezeléséröl is találunk korai feljegyzéseket (Niestadt, 1988; Niestadt, 1990; Siev, Freishtat és Zoltan, 1986).

Többnyire ergoterapeuták alkalmazták a terápiát ez utóbbi esetekben, annak elősegítésére, hogy a páciensek a mindennapi életben szükséges cselekvéseket könnyebben képesek legyenek kivitelezni, illetve a szociális készségek normalizálása érdekében. A gyógytornászok körében is ismert az eljárás, ők a durva motoros készségek, az egyensúly és a testtudat építésére alkalmaztak terápiájuk során szenzoros integrációs terápiás elemeket. Logopédiai tevékenységben való DSZIT alkalmazhatóság a felnőtt rehabilitációra szorulók körében az eddigiekben leginkább a táplálkozási, nyelési zavarok kezelésében merült ki.

Magyar populációra adaptált DSZIT vizsgálóeljárás sajnos nem elérhető, talán ez is oka a rehabilitációs alkalmazás csekély számának. Amerikai tesztanyag rendelkezésünkre áll, melyek támpontot adhatnak arra vonatkozóan, hogy milyen esetekben, milyen eltéréseknél lehet indokolt a szenzoros integrációs terápia alkalmazása (Jongbloed, Collins és Jones, 1986).

A diagnózis felállításában segítségül hívhatjuk a szenzoros integrációs megfigyelési szempontokat, amelyek magukba foglalják a következő területek diagnosztikus megfigyelését:

Vizuális percepció megfigyelése: A téri elemek percepciójára vonatkoztatva mennyire képes a páciens a formákat a megfelelö helyre illeszteni. Figura-háttér percepcióra vonatkozóan a téri pozíció észlelésére teszünk megfigyeléseket. Egyszerübb geometriai minta másolási teljesítményt is megfigyelhetünk.

Szomato-szenzoros percepció megfigyelése: Kinesztézia megfigyelésére alkalmas egy céltábla feladat. Megnézzük, hogy egyszerübb, illetve szokatlan testhelyzetet utánzással képes-e felvenni. Taktilis diszkrimináció próbákat is végzünk: manuális forma percepciót, ujjazonosítási próbát. A grafesztéziát is megfigyeljük, vagyis, hogy mennyire képes 
visszaadni a kézfejre rajzolt formát. Megfigyeljük a páciens tapintásos lokalizációs képességét, illetve kettős taktilis inger percepciós képességét.

Motoros teljesítmény megfigyelése: Szomato-praxis, motoros tervezés: Poszturális kontroll próbával. Ujj- és kézmozgás próbák: Ujj-orr próba, ujj-hüvelykujj próba. Tenyérforgatás, dinamikus sorrendi praxis, ököl-tenyér-él próba. Apróságok a dobozba, cipőfüzés, gombolás. Emberrajz próba, ábrák rajzolása. Vágás próba. Orális praxis: Száj nyitása, nyelvöltögetés, nyelvmozgatás fel-le szájtéren belül, nyelvkörzés. Fújás, csücsörítés, alsó-felső ajkak harapása. Hangok artikulációs mozzanatainak kivitelezése önállóan és/vagy utánzással.

Okulo-motoros praxis: Szemmozgatás. Bilaterális motoros koordináció megfigyelése. Állás egyensúly, tartási egyensúly próbák. Izomerő, izomtónus megfigyelése.

Megfigyeljük továbbá, hogy testközépvonal átlépésére, illetve jobb-bal diszkriminációs próba kivitelezésére képes-e a páciens.

Megfigyeljük az alap mozgásformákat, ülőegyensúlyt, labdadobást.

Magyar nyelven elérhető a Szenzoros Integrációs Leltár (kézirat formájában), ami további szempontokat közvetít a terápia szükségességének megítéléséhez. A leltár a következö területek megfigyelését veszi számba:

- Általános reakciók: környezeti változásokhoz való alkalmazkodás, érzelemkifejezési képesség, szociális kommunikációs képesség, túlérzékenység érintésre, hangra, fényre, figyelmi képességek, pszichomotorium.

- Taktilis feladatok: Öltözködés, egyéb napi feladatok, személyes tér, szocializáció.

- Vesztibuláris feladatok: izomtónus, egyensúlyreakciók, testtartás és mozgás, kétoldali koordináció, térészlelés, érzelmek kifejezése.

- Proprioceptív feladatok: izomtónus, motoros tervezés, öningerlö, önbántalmazó magatartásformák.

Összefoglalva tehát kiknek is ajánlhatjuk a DSZIT-et a rehabilitáción? Ha nagyon leegyszerüsítenénk a választ, mindazoknak, akik „olyan furcsák”, akiknél a hagyományos funkcionális terápiák nagy erőfeszítések mellett sem hoztak eredményt. Természetesen ezt a „furcsaságot” részletesebben is körül tudjuk határolni, vagyis ajánljuk a terápiát azoknak a személyeknek, akiknél szenzoros feldolgozási zavart észlelünk a taktilitás területén, ők azok, akik:

- Érzékenyek különböző anyagú vagy típusú ruhadarabokra: nem tud viselni nyakkendőt, garbót, harisnyanadrágot. Zavarja a ruhában lévő címke.

- Nem szereti a nagy tömeget, a tolakodást, sorban állást, zsúfolt üzletben a vásárlást.

- Irritálják a fények vagy a hirtelen érintés, nehezen alakít ki intim kapcsolatot.

Ajánljuk továbbá a terápiát azoknak a személyeknek, akiknél a szenzoros feldolgozási zavart a vesztibuláris területen észleljük:

- Nehézségei vannak az egyensúllyal, nem szeret egyenetlen talajon sétálni.

- Nem szeret liftben vagy mozgólépcsőn közlekedni.

- Hányingere van a kocsiban, muszáj elől ülnie vagy neki kell vezetni az autót. Nem szeret repülön utazni.

- Nem szívesen hagyja el a házat.

Szenzoros feldolgozási rendszer zavarára utal a hallás területén:

- Érzékeny a hangos hangokra.

- Irritálják bizonyos hangok, például toll vagy ceruza által adott hang a papírlapon írás közben, bizonyos lámpák, fényforrások hangja, evés, rágás hangja, cukorka papírjának a hangja miközben kicsomagoljuk az édességet. 
Szenzoros feldolgozási rendszer zavarának manifesztációja a motoros teljesítményben, ami szintén indikálhatja a terápiát:

- Nehézsége van az autóvezetéssel, parkolással, sebességváltással, autópályára való behajtással.

- Nehézsége van az otthoni vagy az irodai készülékek kezelésével.

- Ügyetlen bizonyos tevékenységekben vagy csak kényelmetlennek érzi: például szabadidős sportokat vagy akár az öngondoskodási feladatokat.

A szociális (társas) teljesítményben megmutatkozó szenzoros feldolgozási zavarra utal:

- Nehézsége van vizuális és auditív jelek értelmezésével.

- Testtudat, testkép zavar, testének határaival nincsen tisztában.

- Nehézsége van az egyes hangok, zajok diszkriminálásával, szóbeli utasítás követésével.

Szenzoros alapú érzelmi szabályozási zavarra utal:

- Vizuális és auditív jelek megkülönböztetésére nem fogékony.

- Nem tudja értelmezni más emberek érzelemkifejező megnyilvánulásait, emiatt harag, frusztráció, szorongás jelentkezhet.

Ha BNO kódok szerint kívánjuk meghatározni, ajánlható a terápia a következő kórképek kiegészítő kezelésére, amennyiben a fent leírt tünetek némelyikét produkálja páciensünk:

1-es BNO szerint: agyi infarktus (I61.0-I69.8), agyállomány vérzett (I.61.x vagy I62.x), koponyaüri sérülés (S06.7, S06.8), agysérülés knm (S06.9), kp-i idegrendszer tumora (mütét után, C71, C72), különféle KIR gyulladások (G04.20, G04.80, G04.90, G05.0, G05.01, G05.02, G05.08), neuropathiák (G60-63).

3-as BNO szerint: Beszédzavarok mno -aphasia, dysarthria, apraxia- (R47), Dyslexia és egyéb jel-dysfunctiók mno, Apraxia, diszpaxia (R48), Beszédhang zavarok (R49).

A szenzoros integrációs deficit megmutatkozik az aphasiákban, dysarthriákban, apraxiákban, dyslexiákban. A motoros beszédzavarok (dysarthria, apraxia) esetében talán nem szükséges részletezni (motorikus érintettség következtében) a mozgásos terápiák létjogosultságát a kezelésben, szintúgy, mint a diszlexia és egyéb tanulási zavarok esetében sem (tekintettel a gazdag szakirodalmi feldolgozottságra: Szvatkó, 1999, Szvatkó, 2002), de az aphasiák esetében célszerü rávilágítani azokra a funkciózavarokra, amelyek a DSZIT segítségül hívását indikálhatják.

A Broca aphasia kiemelkedő tünete az expresszív beszéd zavara, a páciens beszéde nonfluenssé válik, a szavak hangalakja szinte a felismerhetetlenségig torzul, vagyis ebben az aphasiában a fonémikus dezintegrációs zavar kórképe jelenik meg elöttünk, mind a megnevezés próbákban, mind a konverzációban láthatjuk, hogy a szavak elvesztették pontos artikulációs mintájukat, súlyos probléma van a beszédiniciációval (Osmánné, 1997). A tradicionális logopédiai terápia erre a zavarra a fonémikus cue módszerével reagál, a DSZIT ennek alternatív kezelését kínálja terápiás módszereivel. A Broca aphasia esetében szintén dezintegrációs zavarra utalnak a beszédmegértés területén jelentkező eltérések, ugyanis abban az esetben, ha a betegek külön-külön vagy elszigetelten hallanak egy szót, képesek a jelentéssel kapcsolatba lépni, viszont már 2-3 szóból álló kifejezések, mondatok megértésénél jelentkezik a probléma. Itt megjegyezzük, hogy felvetődik a kérdés, hogy ez a deficit a rövid idejü verbális emlékezet zavarára utal-e. A Broca aphasia nyelvi tüneteihez (agrammatizmus: hiányzó toldalékok, ragok, mondatrészek; fonémikus parafáziák; szótalálási nehézségek; nehezített utánmondás; enyhe/középsúlyos beszédmegértési zavar; monoton intonáció) 
viselkedésregulációs problémák is társulnak, aminek kezelésére szintén lehetőséget kaphatunk a DSZIT-böl.

A transzkortikális motoros aphasiában az utánmondási képesség szinte teljes egészében megtartott lehet, de az artikulációs folyamat önálló elindításában súlyos zavar mutatkozik, tehát a beszédiniciációs defektus legalább olyan súlyosan, vagy még súlyosabban manifesztálódik, mint a Broca aphasia esetében (Osmánné, 1997). Ebben az aphasiatípusban figyelhetjük meg leginkább a beteg öngyógyító tevékenységére tett kísérletét, megfigyeléseink alkalmával láthatjuk, amint a páciens megmutatja, hogy milyen tevékenységekkel próbálja akadozó beszédét fluensebbé tenni (leggyakrabban kézmozdulatokat használ kommunikációs rámpaként). Ezen a ponton a DSZIT kiváló terep lehet az öngyógyító folyamat megtámogatásában. A beszédmegértési teljesítmény hasonló képet mutat a Broca aphasiához, viszont határozottabban megjelenik a névszókkal együtt álló, ahhoz való viszonyt jelölő szerkezetek (föleg névutós szerkezetek) dekódolási nehézsége. Illetve gyakran echolálnak ebben az aphasiatípusban a páciensek.

Az izolációs aphasia, mint ahogyan arra az elnevezés is utal, a beszédzónák izolációjának a következménye. A páciensnek erős késztetése van a beszédre, de kommunikációja többnyire üres, információtartalom nélküli, illetve verbális automatizmusokra korlátozódik. Az utánmondási képesség viszonylag ép, de minden más funkció (spontán beszéd, beszédmegértés, megnevezés, írás, olvasás) károsodott. A DSZIT tapasztalati bizonyítékokban megjelenő kiemelkedő eredményeket ér el az idegsejt-kapcsolatok integrációja terén, ezért ajánlható az izolációs problémák kezelésére.

Globális aphasiában mind a spontán beszéd, mind a beszédmegértés, utánmondás, megnevezés, írás, olvasás súlyosan károsodott. Viszont kompenzációs képességükkel egyes páciensek képesek bevonódni a terápiába, többnyire a nonverbális kommunikációs rendszerben képesek eligazodni. Itt a tradicionális logopédiai terápiákra kevésbé építhetünk, leggyakrabban az AAK-t (Alternatív Augmentatív Kommunikáció) ajánlja a szakirodalom, illetve ugyanilyen mértékben létjogosultsága van a mozgásos terápiáknak is, önálló formában mindaddig, míg a nyelvi rendszert nem tudjuk kezelésbe vonni, azt követően pedig kiegészítő terápiás eljárásként.

A Wernicke aphasia tüneteit mutató páciens beszéde fluens, sőt szinte logorreás, de tartalmilag többnyire üres, nem ritkán a páciens által alkotott neologizmusok összefüggö verbális zsargont eredményeznek. Amennyiben elfogadjuk, hogy a Broca aphasiát a fonémikus dezintegráció manifesztációjának tekintjük, akkor a Wernicke aphasia a szavak értelmének a dezintegrációjának a megtestesítője. A kórképhez viselkedési zavar is társulhat, előfordul, hogy nincs tisztában beszédmegértési zavarával, reakciói a szituációhoz inadekvátak lehetnek, ritkán paranoiddá válhat, környezetét hibáztatja beszédmegértési problémáiért, agresszív is lehet ebben az esetben (Osmánné, 1997). A fentiekben kiemelt tünetek indikálhatják a DSZIT alkalmazását a Wernicke aphasia esetében.

A kondukciós (vezetéses) aphasia esetében önmagában a beszédmegértési képesség és a beszédprodukciós képesség is jónak imponál, de a spontán beszéd és az utánmondási képesség között feltűnő a diszkrepancia. Legjellemzőbb tünet (az utánmondási zavar mellett), hogy a páciens tudja mit szeretne mondani, a szót is megtalálja, de beszédprodukciója fonémikus parafáziával telített. A beteg észleli megnyilatkozásának deficitjeit, állandóan javítja magát. A DSZIT segítségül hívható arra az esetre, hogy ez a javítás még a beszédprodukciós megnyilatkozás előtt megtörténjen.

A transzkortikális szenzoros aphasia tünete a parafáziával tarkított beszédprodukció, ami gyakran üres verbalizmust eredményez a konverzációban. Legfeltünőbb tünete az echolália. Vagyis az utánmondás tesztben a leghosszabb mondatot is utánmondja, de értelmezése nem történik meg. Mint ahogyan a Wernicke aphasiánál szenzoros integrációs zavarról beszéltünk, 
ebben az esetben is hasonló a helyzet, tehát a DSZIT jogosultsága ezen a ponton indokolttá válhat.

Az anómikus aphasia bár a fluens típusú aphasiákhoz tartozik, az állandó szókeresés, körülírás igen nehézkes kommunikációt eredményez. A szindróma lényege a megnevezési zavar, amely nem midig hidalható át a Broca aphasiánál bevált fonémikus cue-val (Osmánné, 1997). Talán az anómikus aphasia az az aphasia típus, ami a legeredményesebben kezelhető sérülésspecifikus aphasia terápiával, de az épülés során alkalmazott kompenzációs technikák előhívásában a páciens segítségére lehet a DSZIT.

A szenzoros integrációs terápia hangsúlyos eleme a szenzoros input feldolgozási zavarának a kezelése, különös tekintettel a taktilis és a vesztibuláris-propriocepciós rendszer ingereire vonatkozóan, az inputnak megfelelő adaptív motoros válasz megszületése érdekében. A terápia nem egyenlő képességek építésével, percepciós-motoros kezeléssel vagy szenzoros stimulációval, illetve kognitív tréninggel, a terápia az agy plaszticitására vonatkozó tanulmányokra építve olyan szenzoros ingerek biztosításával foglalkozik, amelyek hozzásegítik az agyat öngyógyító folyamatok véghezviteléhez. Sikeres szenzoros integrációs terápia segíthet a koordináció, az egyensúly, a beszéd, illetve a rágási, nyelési készségek területén, fejlődik a figyelem, ezáltal a beteg rehabilitációban való aktivitási szintje, az énkép, önbizalom és a szociális készségek területén is számíthatunk eredményekre.

A terápia, mint ahogyan az elnevezés is mutatja, dinamikus. Vagyis minden esetben a páciens az irányító személy, a terapeuta a facilitátor. Nondirektív, alkalmazkodunk a páciens önindított tevékenységeihez, csupán hozzásegítjük az adaptív válasz eléréséhez. Annak függvényében, hogy a páciens milyen szintü tevékenységek elvégzésére alkalmas önállóan, változhat a terapeuta aktivitási szerepe, aktív segítőből akár egy terápiás alkalom során is passzív megfigyelövé válhat. Bármilyen aktivitási szerepben legyen is a terapeuta, nagyon fontos, hogy érzelmileg jelen legyen, képes legyen olyan légkört teremteni, amiben a páciens kiegyensúlyozott lehet, örömteli érzés tölthesse el abban a terápiás órában. Nagyon fontos, hogy igyekezzünk hátrahagyni terápiás elvárásainkat, eredménycentrikus szorongásainkat, és csak engedjük magunkat bevonni páciensünk világába. Abban az esetben is, ha betegünk egész terápia alkalmával a felkínált lehetőségek közül csupán egy tevékenységet akar csinálni, bízzunk benne, hogy most számára az a legfontosabb, és közben történik valami a központi idegrendszerben, ami a fejlődését szolgálja. Legyünk hálásak, hogy beengedett a világába, és kísérhetjük ebben a folyamatban, miközben bár látszólag semmi nem történik, ő keményen dolgozik. A terapeuta partner, társ a terápiában, de közben éreztetnie kell biztonságot nyújtó szerepét is. A terápia második fázisa, mikor kihívásokat állítunk a páciens elé, amin keresztuil ő olyan fontos területekhez juthat közel, mint a gondolkodás, társas kapcsolatok, kommunikáció. De ebben a fázisban is nagyon fontos, hogy a páciensünk igényeit, tempóját kövessük. Mindig figyeljünk a reakcióira, és annak függvényében építsük fel saját válaszunkat, következő lépéseinket. Adaptív választ ugyanis csak az „éppen jó” kihívás válthat ki, tehát sem az unalomig ismert és gyakoroltatott cselekvés, sem a páciens számára teljesíthetetlen kihívás. A DSZIT-ben általános elv, hogy ami kellemes, annak integráló hatása van, ami kellemetlen, a pácienst frusztrálja, annak inkább dezintegráló hatása van, mivel túllépi az agy feldolgozó kapacitását (vö. Kiss, 2002).

Célunk a szenzoros ingerek integrálása az adaptív motoros válasz elérése érdekében, amihez új idegsejt kapcsolatok épülése szükséges. A plaszticitás elméletek kutatói igazolták, hogy minden életkorban képes az agy arra, hogy új kapcsolatokat építsen, de nagyon fontos, hogy a nucleus basalis bekapcsolt állapotban legyen. Vagyis a plaszticitás felnőtt korban is jelen van, és ha elegendő munkát fektetünk bele, bizonyos funkciók újraépíthetők. A nucleus basalis bekapcsolása óriási segítséget jelenthetne az agysérülést szenvedett emberek rehabilitációjában, hiszen sok esetben csupán azért nem sikerül olyan tevékenységek, mint az 
írás, olvasás, beszéd vagy éppen a járás elsajátítása, mert nem tudnak eléggé odafigyelni a tanulásra, nem termelődik dopamin és acetilkolin így a plasztikus változások nem tudnak végbemenni. Merzenichtől tudjuk, hogy plaszticitás tekintetében az idős agyban is megtörténhet ugyanaz, mint a fiatal agyban, az egyetlen követelmény, hogy az illetőt megfelelő jutalmazással vagy büntetéssel vegyük rá az igazi odafigyelésre (Doige, 2010).

A szenzoros integrációs eljárások jellemzői (Cermak, 1992):

- Aktív részvétel a terápiában

- Kliens vezérelt

- Személyre szabott

- Tervszerü cselekvések

- Szükséges adaptív válasz

- A kliens válaszaihoz alkalmazkodó változatos input

- Taktilis, vesztibuláris és propriocepciós ingerben gazdag cselekvések

- Implicit és explicit célok az élmények feldolgozásának és rendszerezésének fejlődése érdekében (NEM képességek megtanítása)

- Képzett terapeuta

„A szenzoros integrációs terápia (SZIT) egy nonverbális, mozgásos (pszicho)terápiás forma. Nonverbális, de ez nem jelenti az absztrakt, nyelvi szint teljes negligációját, a hangsúly azonban a történések, változások konkrét, testi szintü megélésén van. Ezt követheti szükség esetén - annak absztrakt feldolgozása. Mozgásos, ami nem jelenti azt, hogy a kliensnek mozognia kell, a terápiás forma - ellentétben pl. a klasszikus pszichoanalízissel, vagy a verbális terápiák nagy többségével - ennek a lehetöségét kínálja fel. A kliens teljes testi valójában van jelen, és a terápiás forma test és lélek állandó kölcsönhatására építve biztosít számára lehetőséget problémáinak konkrét, fizikai szintű „megmunkálására”, feldolgozására, ami implikálja a pszichés feldolgozást is" (Kiss, 2002). A terápia az egyént megakadt fejlödésében segíti tovább a saját útján.

A kommunikációt összetett tevékenységnek, kompetenciának ítéljük meg, amely csakis abban az esetben tud hatékonyan funkcionálni, ha több készséget együttesen kezelünk. Ezért a kommunikációs kompetenciát úgy fejlesztjük, hogy pácienseink mozgását, kognitív kompetenciáját, pszichikumát szintén kezeljük a komplex terápián a célirányos kommunikációs terápiákkal együtt (Szabó, 2007). A komplex kommunikációs terápia nem kizárólag a „,beszédfejlesztésről” szól. A terápiás program feladata növelni a kommunikációs képességet, maximalizálni a pszicho-szociális jóllétét, társadalmi reintegrációját mindazoknak, akik neurogén nyelvi zavarral élnek együtt. Ha egyetértünk ezzel a gondolattal, akkor tudjuk logopédiai terápiánkat szenzoros szemlélettel folytatni, illetve a sérülésspecifikus aphasia, dysarthria terápia mellett a DSZIT-et alkalmazni.

Ha még ennek tükrében is felvetődik a kérdés, hogy miért éppen egy mozgásos terápia járulhat hozzá a logopédiai terápia sikeréhez, elmondhatjuk, hogy a beszéd az egyik leglenyügözőbb motoros tevékenységeink egyike, hiszen megfelelö müködéséhez a központi idegrendszer számos egységének együttmüködésére van szükség. Ezt a felnőttek akkor élik meg, mikor beszédmozgásaikra egy agyi történés következtében kényszerülnek odafigyelni. A beszédprodukciós deficit a motoros beszédzavarok esetében a neuromuscularis és/vagy a motoros vezérlő rendszer károsodásának a következményeként alakul ki. De a DSZIT nemcsak a motoros beszédzavarok, hanem az aphasia kezelésében is ajánlható, mivel az aphasia a beszéd rendszerjellegü zavara, ami kihat a beszédszerveződés minden szintjére, dezintegrálva a kommunikatív funkciót.

Az agyi plaszticitásnak köszönhetően, természetesen a sérülés helyének és nagyságának függvényében, a sérülés következtében elveszített kompetenciák újjáépíthetők, a speciális aphasia terápiákon túl, a szenzoros ingerek feldolgozásában, rendszerezésében, 
összehangolásában nyújtott megsegítéssel, ezáltal a pácienst hozzásegítve az adaptív motoros válasz megtalálásához. Az alábbiakban kiemelem azokat a területeket, amelyek biztosan helyet kell kapjanak a stroke rehabilitációban, és aminek a kezelésére a DSZIT kiegészítő terápiás eljárásként alkalmas lehet:

- Szenzoros alapú mozgás-rendellenességek kezelése

- Poszturális zavarok kezelése

- Test stabilitásának erősítése

- Izomtónus és a mozgáskontroll adaptivitásának elősegítése

-Egyensúlyozás

- Testsúly finom áthelyezése

- Felegyenesedési reakciók

- Mozgásintolerancia kezelése

- Diszpraxia kezelése

- Mozgástervezés- szekvenciálás- és a kivitelezés problémájának a kezelése

- Test elhelyezése a térben, viszonyítása a környezet tárgyaihoz, személyeihez

- Időzítés, erőbefektetés adaptivitásának fejlesztése

- Finommotoros manipuláció és az orális-motoros tevékenység rendezése

- Új iránti érdeklődés felkeltése

- Öltözködés, eszközhasználat gyakorlása

A tengeren túli szakirodalom a csoportterápiás formát részesíti előnyben költséghatékonyság miatt, illetve ebben a formában képesek a páciensek leginkább egymástól tanulni. Rehabilitációs alkalmazásban (föleg a fekvőbeteg ellátásban) tapasztalatom szerint a kezdeti időben mindenképpen az egyéni terápiás forma javasolható. Nagyon fontos, hogy megismerjük ebben a fázisban páciensünket, hagyjunk időt magunknak megfigyelni tüneteit és neki ahhoz, hogy feltárja előttünk azokat. Csakis ebben az esetben tudjuk értelmezni, hogy a fejlődés mely pontján valószínüsíthető az elakadás. Továbbá tudnunk kell, hogy mikor a rehabilitációs folyamatba belép a kliens, bár együttmüködőnek tünik, de még az állapotának elfogadásában nagyon az út elején tart. Helyzetét, félelmeit, gyengeségeit, haragját nem szívesen osztaná meg még mással. Ha minket, terapeutákat beenged a világába, az éppen elég ennek a hosszú útnak az elején. A csoportterápia egy későbbi stádiumban lehet indokolt, ha abba a formába a páciens is bevonódni kíván, illetve, ha a terapeuta elég felkészültnek érzi magát ehhez.

A terápia eszköztára a fejlődés segítője lehet, ha társul hozzá egy, a fentiekben kifejtett személyiséggel, tudással rendelkező terapeuta. Egyszerü eszközökről van szó, mint a terápiás nagylabdák, függőágyak, hinták, szivacsok, billenő, guruló, ingatag eszközök, de fontos, hogy ezeknek felnőttekre adaptált változata. A rehabilitációra szorulók körében nem biztos, hogy tudjuk alkalmazni például a gördeszkát, de ezt kiválóan helyettesíthetjük a kerekesszékkel (Breines, 1988). Az eszközök azonban csakis elfogadó légkörben, vidám hangulatban tudják betölteni szerepüket. Önmagukban, vagyis az eszközök segítségével történő funkciógyakoroltatás, „tornáztatás” nem tekinthető DSZIT-nek.

Hangsúlyozzuk, hogy a rehabilitációban nincs egyetlen üdvözítő terápiás eljárás, de a dinamikus szenzoros integrációs terápia kiegészítő terápiája lehet a sérülés-specifikus egyéb terápiáknak.

\section{Irodalom}

Ayres, A. J. (1972/1999). Sensory Integration and Learning Disorders, Western Psychological Services, Los Angeles; szemelvényes fordítás in: Szvatkó, A., Varga, I. 
(szerk.) (1999). Szenzoros Integrációs Terápiák, Tanfolyami segédanyag, kézirat, Budapest, 5-31.

Ayres, A. J. (1979/1999). Sensory integration and the child, Western Psychological Services, Los Angeles; citat: Arendt és mtsi (1991).; ill. az első és második fejezet fordítása in: Szvatkó, A., Varga, I. (szerk.) (1999). Szenzoros Integrációs Terápiák, Tanfolyami segédanyag, kézirat, Budapest, 32-49.

Bedő, I. (1999). Ritmus, autista gyermekek szenzoros integrációs terápiájának lehetöségéröl és a ritmus terápiás jelentőségéről, in: Szvatkó, A., Varga, I. (szerk.) (1999). Szenzoros integrációs terápiák, Tanfolyami segédanyag, kézirat, Budapest, 71-77.

Breines, E. (1988). The w:heelchair: An adult scooter board. Physical and Occupational Therapy in Geriatrics, 6, 25-33.

Bundy, A. (1991). Play theory and sensory integration, in: Fisher, A. G., Murray, E., Bundy, A. (szerk.) (1991). Sensory Integration, Theory and Practice, F. A. Davis Company, Philadelphia, 46-68.

Campos, J. A. (2000). A mozgásterápiás folyamat és lehetséges elméleti háttere, Kézirat.

Cermak, S. A. (1992). Sensory Integration with the Adult: Application and Misapplication. The Israel Journal of Occupational Therapy, Vol. 1, No. 3: E57-E74.

Cross, L. A., Coster, W. J. (1997). Symbolic play language during sensory integration treatment, American Journal of Occupational Therapy, Vol 51(10), 808-814.

Doige, Norman (2010). A változó agy. Budapest: Park Könyvkiadó.

Fisher, A. G., Murray, E., Bundy, A. (szerk.) (1991). Sensory Integration, Theory and Practice, F. A. Davis Company, Philadelphia, 71-107.

Gielow, D., Hobler, R. (1986). Sensory integrative activity in nursing home residents' cognitions, affect, self-esteem and behavior. Perceptual and Motor Skills, 62, 637-638.

Hegyi Ágnes (1995). Afáziaterápiák. Javaslat az afázia kognitív nyelvi terápiájára. Budapest: Nemzeti Tankönyvkiadó.

Jongbloed, L., Collins, J., Jones, W. (1986). A sensorimotor integration test battery for CVA clients: Preliminary evidence of reliability and validiti. Occupational Therapy Journal of Research, 6, 131-150.

Jongbloed, L., Stacey, S., Brighton, C. (1989). Stroke Rehabilitation: Sensorimotor Integrative Treatment Versus Functional Treatment. American Journal of Occupational Therapy, Vol. 43, 391-397.

Kagan, Aura (1998). Supported conversation for adults with aphasia: methods and resources for training conversation partners. Aphasiology, 12(9), 816-38.

King, L. J. (1974). A sensory-integrative approach to schizophrenia. The American Journal of Occupational Therapy, 28: 529-536.

KISS, T. C. (2002). A Szenzoros Integrációs Terápia és holisztikus kiterjesztése, a Holisztikus Szenzoros Balansz, Tudomány és Lélek, Vol. 4, No. 6, 72-97.

Niestadt, M. (1988). Occupational therapy for adults with perceptual deficits. The American Journal of Occupational Therapy, 42, 434-440.,

Niestadt, M. (1990). A critical analysis of occupational therapy approaches for perceptual deficit sin adults with brain injury. The American journal of Occupational Therapy, 44, 299-304.

Osmánné S. J. (1997). Az afáziák neurolingvisztikai alapjai. Budapest: Nemzeti Tankönyvkiadó.

Riggan, J. S. (1983). A learning abilities program for learning disabled soldiers. Occupational Therapy in Mental Health, 3, 49-54.

Ross, M., Burdyck, D. (1981). Sensory integration: A training manual for therapists and teachers for regressed psychiatric and geriatric patient groups. Thorofare, New Jersey: Charles B. Slack. 
Siev, E., Freishtat, B., Zoltan, B. (1986). Perceptual and cognitive dysfunction int he adult stroke patient. Revised edition. Thorofare, New Jersey: Slack.

Spitzer, S., Smith Roley, S., Clark, F., Parham, D. (1996). Sensory Integration: Current Trends in the United States. Scand J Occup Ther. 3: 123-138.

Szabó E. (2007). Az afázia csoportterápiás kezelése. Beszédgyógyítás. 18 (1), 29-58.

Szvatkó A. (2002). Hiszen ez játék! - Szenzoros integrációs terápiák a fejlesztésben. In: Martonné Tamás Márta (szerk.): Fejlesztőpedagógia. Budapest: Eötvös Kiadó.

Szvatkó, A. (1999). Bevezetés a szenzoros integrációs terápia szemléletébe, in: Szvatkó A., Varga I. (szerk.) (1999). Szenzoros integrációs terápiák, Tanfolyami segédanyag, kézirat, Budapest, 50-56. 


\title{
TANULÁSBAN AKADÁLYOZOTT GYERMEKEK KOGNITÍV FEJLESZTÉSÉNEK LEHETŐSÉGEI
}

Szerzők:

Orbán Réka

Babes Bolyai Tudományegyetem

(Románia)

Szerző e-mail címe:

reka.orban@ubbcluj.ro

\section{Lektorok:}

János Réka

Babes Bolyai Tudományegyetem

(Románia)

Kiss Szidónia

Babes Bolyai Tudományegyetem

(Románia)

Mező Ferenc

Debreceni Egyetem

Mezö Katalin

Debreceni Egyetem

Orbán Réka (2015): Tanulásban akadályozott gyermekek kognitív fejlesztésének lehetőségei. Különleges Bánásmód, I. évf. 2015/2. szám, 81-86. DOI 10.18458/KB.2015.2.81

\begin{abstract}
Absztrakt
Jelen tanulmány a Sindelar-Zsoldos program alkalmazását mutatja be egy tanulásban akadályozott elemi osztályos gyermek esettanulmányán keresztül. Az elméleti rész a tanulásban akadályozott tanulók kognitív struktúrájára fókuszál. A módszertani rész azt fejti ki, hogy ha a kognitív struktúra harmonikus, akkor egy tanulásban akadályozott gyermek is sikeres lehet az iskolában és a teljes inklúzió lehetségessé válik.
\end{abstract}

Kulcsszavak: kognitív fejlesztés, kognitív képességek, Sindelar-Zsoldos program

Diszciplina: gyógypedagógia

\begin{abstract}
POSSIBILITIES OF COGNITIVE DEVELOPMENT OF CHILDREN WITH LEARNING DIFFICULTIES

This study presents the Sindelar-Zsoldos program through a case-study of an elementary school boy with learning difficulties. The theoretical part is focused on the cognitive structure of the learning of disabled students. The methodological part emphasizes that if the cognitive architecture is harmonized, then even a child with learning difficulties can be successful in the school and full inclusion is possible.
\end{abstract}

Keywords: cognitive development, cognitive skills, Sindelar-Zsoldos program

Disciplines: special education 


\section{Az értelmi akadályozottság fogalma és kognitív jellemzői}

A tanulásra való képesség az emberi létezés meghatározója és minőségének, fejlettségének mutatója. A tanulási folyamat szorosan összefügg az értelmi szint fejlődésével, de nem azonos vele, bizonyos esetekben színvonala magasabb lehet, mint az értelmi teljesítmény (Mesterházi, 1995).

A tanulásban akadályozottakra jellemző a kognitív müködés generalizált korlátozottsága, illetve számos képességük hiányzik vagy számottevően gyenge. A kognitív, nyelvi, motoros, pszicho-szociális képességek zavara erőteljesen befolyásolja mindennapi életüket (Westendorp és tsai, 2011).

Sarkady Kamilla és Zsoldos Márta (1992/93) vizsgálatai alapján elkülöníthetőnek tartja a tanulásban akadályozottak azon populációját, akik specifikus tanulási zavarokkal is küzdenek.

Tanulási zavarnak tekintik azt az - intelligenciaszint alapján elvárhatónál lényegesen alacsonyabb tanulási teljesítményt, amely neurológiai deficit vagy funkciózavar talaján jön létre, sajátos kognitív pszichológiai tüneteggyüttessel. A tanulási zavar társuló tünetként megjelenhet enyhe értelmi fogyatékosságnál, érzékszervi sérülésnél és beszédhibáknál. Ezekben az esetekben is (specifikus) tanulási zavarról beszélünk.

A legutolsó meghatározás a DSM-V (2013) valamennyire eltér az előzőektől: A személy hatékony és pontos észlelését és információ-feldolgozását zavaró sajátos nehézségeket nevezzük specifikus tanulási zavarnak. Ennek az idegrendszeri fejlődési zavarnak a tünetei az első iskolai években jelennek meg. Jellemző az olvasás, írás és/vagy matematikai képességek kialakulásának tartós zavara. A teljesítmény az érintett területen jelentősen elmarad a korosztályától elvárttól, vagy az elfogadható teljesítmény elérése nagy erőfeszítést igényel. Tanulási zavar elöfordulhat tehetséges személyeknél is, ilyenkor a tünetei csak akkor jelentkeznek, ha a felmérési eljárások vagy a tanulási követelmények olyan akadályt jelentenek, melyeket nem tud természetes intelligenciájával és kompenzációs stratégiákkal legyőzni. A specifikus tanulási zavarok egész életen át problémát jelentenek azokban a tevékenységekben, amelyekben ezekre a képességekre kell támaszkodnia, beleértve a munkahelyi teljesítményt is.

Piaget (in Demetriou, Shayer és Efklides, 1994) megismerésröl alkotott kognitív konstruktivista elmélete nagyban hozzájárult az információfeldolgozással kapcsolatos elméletek fejlődéséhez, melyek a kogníciót „folyamat-egésznek” tekintik, és amelyek körülhatárolt részei a részképességek: észlelés, figyelem, emlékezet, intermodalitás, szerialitás, téri orientáció.

Brigitte Sindelar (Sedlak és Sindelar, 2000) a kognitív képességek egy hierarchikusan szerveződő struktúrában helyezhetők el és a sikeres tanuláshoz ezek megfelelő müködése és együttmüködése kulcsfontosságú, a problémás gyermekek képességprofilja diszharmonikus. A részképességek elemi bázisfunkciók, melyek müködése és összerendeződése előfeltétele a komplexebb mentális müveleteknek, problémamegoldásnak, intelligenciának, az írás-, olvasás-, és számolási készségek kialakulásának (Affolter, 1972, Sindelar, 1994, Zsoldos, 1999).

A szenzomotoros rendszer differenciált fejlesztését célozza, és nagy hangsúlyt fektet a megelőzésre. Programját Affolter (1972) háromdimenziós észlelésfejlődési modelljére alapozva dolgozta ki. A vizuális, auditív és taktilo-kinesztéziás észleletek három fö kognitív területen, az emlékezeten, észlelésen és figyelmen keresztül, valamint három fejlödési szinten, modalitás-specifikus, intermodális és szeriális felfogáson át vezetnek azokhoz a magasabb rendü képességekhez, amelyek lehetővé teszik többek között az írás, olvasás és számolás elsajátítását is. A rácsszerkezet bármely pontján keletkező deficit gátja lehet az iskolában szükséges képességek kialakulásának. Sindelarnak a részképesség-kiesés vagy -gyengeség területének azonosítására kidolgozott vizsgálati módszerei és a korrekciót szolgáló gyakorlatok ezen gyenge pontok feltárására, illetve megerősítésére szolgálnak. 
Minden alulteljesítő diák jól tanítható. A leghatásosabb, ha minden gyereket egyéni sajátosságai, szükségletei szerint oktatunk, ezzel egyenlő esélyt biztosítunk számukra. A jó tanítás érdekes, tanulásra motiváló órák tartását jelenti. Ehhez szükséges, hogy a tanár megértse a tanulók egyéni szükségleteit, és ezeknek megfelelő oktatási programot dolgozzon ki.

A kognitív architektúra alappillére az észlelés (Kiss, Zsoldos, 2008). Engel-Yeger, HardalNasser, és Gal (2011) kutatása kimutatta, hogy az értelmileg akadályozottak szenzoros feldolgozási képességei atipikusak. Figyelmük önkéntelen, spontán, kevésbé tartós, könnyen elterelhető, valamint hullámzó és szétszórt. Hiányzik a figyelem megosztására való képesség (Szabó, 2006). Neuropszichológiai kutatások azt mutatják, hogy a figyelemzavarok jelentős tényezője a kognitív fejlődési rendellenességeknek, ami hátráltatja a tanulásban, az észlelésben és a motoros funkciókban az értelmileg akadályozott gyerekeket (DjuricZdravkovic, Japundza-Milisavljevic és Macesic-Petrovic, 2010).

Térben bizonytalanul tájékozódnak, a téri relációkat bizonytalanul ismerik fel és határozzák meg. Az egyszerübb téri helyzeteket, mint például a föl, le, elöre, hátra, stb. gesztusokkal kísért utasításokkal viszonylag gyorsan megértik, megtanulják, és végre is hajtják, azonban önállóan reprodukálni majd csak jóval később tudják. Az értelmileg akadályozott személyek körében a térbeli memória kapacitása csökkent (Alevriadou, 2010).

A továbbiakban a Sindelar-Zsoldos program alkalmazhatóságát mutatom be tanulásban akadályozott és specifikus tanulási zavaros gyermekre egy esettanulmány formájában.

\section{Az eset ismertetése}

Tíz éves, harmadik osztályos fiú. A szakértői bizottság véleményezése alapján tanulásban akadályozott, teljesítménye hullámzó és bizonyos feladatokban az elvártnál is sokkal gyengébben teljesít. A szülő kérte a felmérést, mivel a rendszeres foglalkozások ellenére sem javul az iskolai teljesítménye. A gyermek nagyon jó magaviseletü, könnyen kezelhetö, igyekvő, bármilyen feladatot szívesen elvégez. Szemüveges.

A gyermek legfontosabb anamnesztikus adatai: Problémamentes terhesség után, időre született (3600 g és $53 \mathrm{~cm}$ hossz). Nyugodt gyermek volt, könnyen alkalmazkodott, 3 hónapos korától átaludta az éjszakát. Járni 2 év és 1 hónaposan kezdett, a kúszás, mászás szakasza kimaradt a mozgásfejlődéséből. Beszédfejlődése nagyon lassan indult, most is halk és szükszavú, szókincse szegényes.

A szülö véleménye a gyermek jelenlegi fejlettségi szintjéről: Nagyon jó gyermek, segítőkész, sok mindent rá lehet bízni. Mosolygós, csendes, elfoglalja magát, sosincs vele különösebb baj. Kitartóan végzi a feladatait, és mégis gyengék a minősítései. Nem elégedett a fejlettségi szinttel, de az iskolától és a szakemberektől vár megoldást, hisz otthon minden rendben van.

Rövid pedagógiai vélemény: Nagyon visszahúzódó, szorongó, csendes gyermek. A tanulási kudarcok megviselik, emiatt gyakran szomorú. Feladatvégzéskor nagyon lassú, emiatt gyakran a szünetet is tanulásra szánja. Kimondottan müvészi hajlamú gyermek, szépen rajzol. A pedagógus nem érti hullámzó teljesítményét, például a verset délután felmondja, de másnap reggel már nem tudja.

Szegényes szókincse és szövegértési problémái miatt azonban az anyanyelv és matematika (föleg a szöveges feladatok) teljesítménye gyenge. Ha felolvassák közösen a feladatot és utána kérik a megoldást, jobban teljesít, mintha magában kellene elolvasnia azt.

Ezeken a területeken sokszor rosszabbul teljesít, mint egyik osztálytársa, akit értelmileg akadályozott kategóriába soroltak.

\section{A vizsgálóeljárás bemutatása}

A Sindelar vizsgálóeljárás részletes képet nyújt az iskoláskorú gyermekek kognitív architektúrájáról és alapvetően különbözik a pszichológiai tesztektől. A dinamikus, fejlesztési 
stratégia célja nem csupán az állapot meghatározása, hanem fejlődési, fejlesztési lehetőségek, irányvonalak kijelölése, az egyén tanulási, fejlődési potenciáljának megismerése. A hagyományos pszichometriával ellentétben, amely a kvantitatív mérésekre összpontosít, a fejlesztési diagnosztika a kvalitatív tényezőkre, a képességek minőségi elemzésére és értékelésére helyezi a hangsúlyt. A dinamikus felmérés a statikus tesztektől a céljaiban, folyamataiban, eszközeiben, értékelési helyzetében és az eredmények kiértékelésében különbözik (Falik és Feuerstein, 2005; Sindelar, 2010).

A tizenhét feladat kilenc kognitív képességet vizsgál, melyek az affolteri koncepcióban meghatározzák az iskolai teljesítményt. A bázisfunkciókon kívül kiterjed az intermodális és a szeriális képességek vizsgálatára is (Sindelar, 2010).

A részletes eredmények alapján választjuk ki a személyre szabott tréningprogramot.

\section{Az eredmények értelmezése}

A pedagógust igazolja, hogy nagyon lassan oldotta meg a feladatokat, hamar fáradt, így a vizsgálat során az elöírtnál sokkal több szünetre volt szüksége. Feltünően próbált a vizuális feladatokban olvasással, illetve szóbeli megfogalmazással kompenzálni (intermodális szintre emelve a feladatot).

A vizuális alak-háttér differenciálás feladatból kiderül, hogy vonalvezetése bizonytalan, a formákat megrajzolja, de a síkban nem tudja elhelyezni őket, forgatta a lapot a feladat elvégzése közben, sokszor fejjel lefelé tartotta, ezzel kompenzálva a síkbeli orientációs problémáit. Nagyon sok hibával dolgozott.

A vizuális szerialitást mérő feladatot nehezen értette meg, de a megértési nehézség leküzdése után szinte hibátlanul megoldotta a feladatot.

Az intermodális emlékezet feladatban kiderült, hogy kockázatvállalással próbálta növelni a helyes válaszok számát, de kevés hibát ejtett.

Az auditív alak-háttér differenciálás/tagolás feladatban azoknál a hangoknál rontott, melyeket írásban is felcserél.

Auditív emlékezet (versike megtanulása): a rövid részeket hibátlanul visszamondta elsőre, a teljes vers visszamondásánál a második sorban elakadt, kihagyta a végét és a negyedik sor első szavánál segítséget igényelt.

A téri orientációja bizonytalan, hét feladatból ötöt rontott.

A vizsgálat alatti magatartás elemzése: a vizsgálat alatti magatartása megfelelt annak, amit anyukája és tanítója is tapasztalt. Az új helyzetben kezdetben szorongó volt, de hamar oldódott. Nagyon készséges volt a kislány, jól lehetett vele dolgozni, és kiderült az is, hogy az iskolában feltünő lassúsága a kompenzálásnak köszönhető. A kompenzálásnak köszönhetően megnyúlt a végrehajtás ideje, de ugyanakkor ez is világossá tette, hogy a gyerek végre akarja hajtani a feladatot, csak nem képes rá.

A sikeresen megoldott feladatok növelték a motivációját. Ilyenkor a szünetet is kihagyta volna, csakhogy újabb sikerélményhez jusson. Reálisan értékelte a saját teljesítményét.

A fejlesztési program kijelölése és a fejlesztés megszervezése: a négy alapterület, melyen gondjai voltak: a vizuális alak-háttér megkülönböztetése, az auditív és vizuális differenciálás, valamint a téri orientáció - ennek megfelelően az Útmutató (2010) alapján a 142-es tréningprogramot alkalmazzuk. A tanító végzi a napi fejlesztést, melyet kiegészít az a meixneri alapelveken nyugvó diszlexia-terápia (föleg tévesztett betük: $c-c s, s z-z s, s-s z, z-z s$, és az ékezetes betűk) újratanítása és differenciálása. A tréningprogramhoz szükséges anyagokat biztosítom a tanító számára és konzultálok vele, bemutatom az újabb gyakorlatot, valamint a gyermekkel is találkozom hetente egyszer. 


\section{A fejlesztés eredményei}

A tízperces időkeret és a sikerélmény biztosítása jelentette az első eredményeket. Ha a felmérőkor azt hallotta, hogy tízperces feladatról van szó, akkor nagyon motiválttá vált és sikerorientálttá vált a magatartása, ez a fokozott figyelem pedig az érdemjegyben is tükröződött.

\section{Az elsö tréningfázis}

A vizuális alak-háttér 1+2-es füzet feladatlapjait könnyedén megoldotta, néha szükséges volt egyik-másik feladat megismétlése, mert hibázott a részletek kivitelezésében.

A téri orientáció füzet első feladatai, melyek a taktilis észlelést fejlesztik, szintén könnyüek voltak, a mozdulatutánzásos feladatok azonban már nehezebbeknek bizonyultak, a jobb-bal irányok differenciálása miatt. A robotjátékban végül sikerélménye volt, így azt többször is játszottuk jutalomként is.

Az auditív differenciálás esetében nehézséget a hasonló hangok differenciálása jelentette, amikor nem ismételhette meg a szavakat.

\section{A második tréningfázis}

A hosszú és rövid hangok auditív differenciálása elég könnyedén ment, viszont a történetek olvasása után hangsúlyt kapott a szókincsbővítés is.

A vizuális differenciálás feladatok ismerősek voltak, és viszonylag könnyen mentek. Az apró különbségeket mediálni kellett, de a másodszori vagy harmadszori kirakás már helyes volt.

A téri orientáció „építős” feladatai nagyon tetszettek neki, miután megértette, mit jelent minta alapján építeni, jól haladt. Elakadás a sziluett kép utáni építéskor következett be, de néhány próbálkozás után jól megoldotta.

\section{A harmadik tréningfázis}

A vizuális alak-háttér differenciálás feladatok során meg kellett tanulnia az ábécé-sorrendet, ezt külön mediálni kellett, és részletekben megtanítani, ahhoz, hogy használni tudja a feladatmegoldáshoz. A későbbiekben viszont a szótárhasználathoz is szükséges lesz. A végén pedig szüksége volt a szókincsbővítésre ahhoz, hogy az adott betüt tartalmazó szavakat megtalálja. Az auditív differenciálás feladatokban a tévesztett hangpárokat többször is gyakorolnunk kellett. A téri forgatás feladatokat nehezen értette meg, de végül sikeres volt. A vizuális differenciálás feladatokat jól megoldotta.

\section{Következtetések}

A másfél éves fejlesztőprogram hatására a gyermek kognitív architektúrája harmonikussá vált, javult az olvasási technikája és helyesírása. Két éve már nem igényel segítséget, jól teljesít az általános iskolában.

\section{Irodalom}

Affolter, F. (1972). Az észlelési funkciók zavartalan és patológiás fejlodésének szempontjai. Torda Á. (1992, szerk.). Szemelvények a tanulási zavarok körébol. Tankönyvkiadó, Budapest

Alevriadou, A. (2010). Spatial location of movement by children with intellectual disabilities: Automatically encoded or not?. Proocedia Social and Behavioral Sciences 2, 4707-4711. 
American Psychiatric Association (ApsyA) (2013). Diagnostic and Statistical Manual of Mental Disorders (V. ed.) (pp. 66-84) Washington DC: American Psychiatric Association

Demetriou, A., Shayer, M. és Efklides, A. (1994). Neo-Piagetian theories of cognitive development. Routledge, London

Djuric-Zdravkovic, A., Japundza-Milisavljevic, M. és Macesic-Petrovic, D. (2010). Attention in children with intellectual disabilities. Procedia Social and Behavioral Sciences 5, 1601-1606.

Engel-Yeger, B., Hardal-Nasser, R. és Gal, E. (2011). Sensory processing dysfuntions as expressed among children with different severities of intellectual developmental disabilities. Research in Developmental Disabilities 32, 1770-1775.

Falik, L. H. és Feuerstein, R. S. (2005). The current state and development of the learning propensity assessment device (LPAD). Erdélyi Pszichológiai Szemle, különszám, 17-54.

Kiss, A. és Zsoldos M. (2008). A képességrendszer változásai fejlesztésben részesülő tanulóknál. A Sindelar-program tapasztalatai. In Németi, J. (ed.). Tanulmányok a tanulásban akadályozottak pedagógiája és határtudományai köréböl. Sulinova, Educatio Társadalmi Szolgáltató Közhasznú Társaság, Budapest

Mesterházi, Zs. (1995). A tanulási képességről és a tanulási akadályozottságról. Gyógypedagógiai Szemle, XXIII./1, Magyar Gyógypedagógusok Egyesülete, Budapest.

Sarkady, K. és Zsoldos, M. (1992/93) Koncepcionális kérdések a tanulási zavar körül. Magyar Pszichológiai Szemle, 3-4, 259-270.

Sedlak, F. és Sindelar, B. (2000). "De jó, már én is tudom!"ELTE - BGGYTF, Bp.

Sindelar, B. (1994). Teilleistungsschwächen. Wien, Eigenverlag

Sindelar, B. (2010). Vizsgálóeljárás az iskolás gyermekek részképességeinek felismerésére a Tréningprogram használatához. Nyomdaipari és Kiadói Szolgáltató Kft, Budapest

Sindelar, B. (2010). Útmutató. Nyomdaipari és Kiadói Szolgáltató Kft, Budapest

Szabó B. (2006). Inkluzív nevelés. Ajánlások értelmileg akadályozott gyermekek kompetencia alapú fejlesztéséhez. - Óvodai nevelés. SuliNova Közoktatás-fejlesztési és Pedagógus-továbbképzési Kht., Budapest

Wastendorp, M., Houwen, S., Hartman, E. és Visscher, C. (2011). Are gross motor skills and sports participation related in children with intellectual disabilities? Research in Developmental Disabilities, 32, 1147-1153.

Zsoldos, M. (1999). A tanulási és magatartási zavarok kognitív terápiája- A Sindelarprogram. Gyógypedagógiai szemle. 27/2, 94-101. 


\title{
A SZOCIÁLIS KOMPETENCIA FEJLŐDÉSE A HÁTRÁNYOS HELYZETÚ GYEREKEKNÉL
}

\section{Szerzők:}

Bagány Ágnes

Újvidéki Egyetem (Szerbia)

Major Lenke

Újvidéki Egyetem (Szerbia)

Josip Lepeš

Újvidéki Egyetem (Szerbia)

Első szerző e-mail címe:

agnes.torteli@magister.uns.ac.rs
Lektorok:

Horák Rita

Újvidéki Egyetem (Szerbia)

Pintér Krekity Valéria

Újvidéki Egyetem (Szerbia)

Schéder Veronika

Debreceni Egyetem

Mező Katalin

Debreceni Egyetem

Bagány Ágnes, Major Lenke és Lepeš, Josip (2015): A szociális kompetencia fejlődése a hátrányos helyzetü gyerekeknél. Különleges Bánásmód, I. évf. 2015/1. szám, 87-94. DOI 10.18458/KB.2015.2.87

\begin{abstract}
Absztrakt
2010 szeptemberében az oktatási reformmal, vagyis az inklúzió bevezetésével Szerbiában ugrásszerüen megnött a hátrányos helyzetü és halmozottan hátrányos helyzetü gyerekek beiskolázása. 2013 szeptemberétől az Újvidéki Egyetem Magyar Tannyelvü Tanítóképzö Kara és a Szegedi Tudományegyetem Juhász Gyula Pedagógusképzö Kar Felnöttképzési Intézete egy közös projekt keretén belül kidolgozott egy programot, ahol a két intézmény hallgatói mentorokként vettek részt a hátrányos helyzetü gyerekek felzárkóztatásában. Tanulmányunk célja bemutatni a Hallgatói Mentorprogram felépítését, amely jó gyakorlatul szolgálhat hasonló problémákkal küzdö iskolák számára. A gyakorló pedagógusok véleménye alapján a mentorprogram hosszú távú hatásaként kiemelnénk a mentorált tanulók szociális kompetenciáinak fejlödését.
\end{abstract}

Kulcsszavak: hátrányos helyzet, mentorprogram, felzárkóztatás, szociális kompetencia

Diszciplínák: pedagógia, gyógypedagógia, pszichológia

\footnotetext{
Abstract

DEVELOPMENT OF THE SOCIAL COMPETENCE OF CHILDREN FROM AN UNDERPRIVILEGED BACKGROUND

In September, 2010, by the introduction of the educational reform in Serbia, namely the introduction of inclusion, the number of children from a disadvantaged background and multiple disadvantaged background has significantly increased. From September 2013, the University of Novi Sad, Faculty of Education in Hungarian Language, Subotica and
} 
University of Szeged, Gyula Juhász Faculty of Education, Institute of Adult Education worked out a programme, in which the students of these two Universities participated as mentors in the compensatory education of disadvantaged children. The purpose of the present study is to introduce the structure of the Student Mentoring Program that serves as an excellent example for other schools. According to in-service teachers, one of the long-term positive outcomes of the mentoring program is the development of social competences of disadvantaged children.

Keywords: disadvantageous background, mentoring program, compensatory education, social competence

Disciplines: pedagogy, special education, psychology

\section{Inklúzió és a szociális kompetencia}

Az inklúzió - mint az exklúzió, a kirekesztés ellentétes irányú folyamata - elősegíti az eredményesség növelését, ha meghatározó formává válik a különböző képzési formákban, közösségekben. Alapvető célja, hogy eszközrendszerével csökkentse a kizárásra irányuló nyomást az iskolában és a társadalomban. Az inklúzió azt jelenti, hogy az egyes kultúrákhoz és közösségekhez tartozók befogadása soha be nem fejeződő folyamat, állandó munka egy ideálért, amikor a társadalomban tapasztalható kizárási kényszerek eltünnek. A befogadó iskola a közösség oktatásának a forrása, és maga az oktatás több mint az iskoláztatás cselekvés a közösséggel, a közösségben, a közösségért (Kalocsainé és Varga, 1995).

Az új szerbiai oktatási kerettörvény szövegéből a nem jogvégzett ember is ki tudta olvasni, hogy a kötelező beiskolázás terén 2010 szeptemberében jelentős változások léptek hatályba. A beiratkozás korhatárát már korábban is egy fél évvel előbbre tették, hét esztendő helyett hat és fél éves korában minden gyermeknek az iskolapadban van a helye. Eddig az iskolaelőkészítő folyamat során külön-külön vizsgálták minden egyes tanuló pszichofizikai és szociális érettségét, s ennek alapján esetleg későbbre lehetett halasztani az elsőbe indulást. Ha pedig ezt egy erre szakosodott komoly bizottság (melyben gyermekgyógyász, pszichiáter, pszichológus, defektológus és szociális gondozó is helyet kapott) jónak látta, kisegítő tagozatba vagy a különleges igényekkel élő gyermekek oktatására és nevelésére szakmai és tárgyi szempontból felkészült szakintézményekbe utalta (Törteli, 2014).

Az egymástól eltérő családi hátterü, hátrányos szociális vagy gazdasági helyzetü tanulók inkluzív oktatása nagy nehézségekbe ütközött az új oktatási politika bevezetésével. A kérdés az, hogy a különbözö hátterü gyermekeket együtt vagy külön érdemes-e oktatni, milyen módszereket érdemes alkalmazni, és mindez milyen hatással lehet a roma és nem roma, hátrányos helyzetü és nem hátrányos helyzetü gyermekek fejlődésére (Kézdi és Surányi, 2008). A szerbiai inkluzív pedagógia a sajátos oktatási, nevelési igényü tanulóknál nem foglalkozik kellő alapossággal az eltérö hátterü tanulók együttnevelésével, holott Forray és Hegedüs (1998) szerint a cigány családok és az iskola közti feszültség egyik fő forrása a nevelési célokról, nevelési feladatok megosztásáról való eltérő vélekedés lehet. Az oktatási intézmények úgy tartják, a sikeres nevelés és oktatás egyik alappillére, ha a szülők együttmüködnek az adott intézménnyel, hogy a pedagógus mind jobban folytatni tudja azt a nevelési stratégiát, amit a szülő otthon elkezdett, felmérje időközben a családi hátteret, és felmérések után a pedagógus jobban tud igazodni a gyerekhez, könnyebben megérti az esetlegesen felmerülő, iskolában/óvodában kialakult problémák okát, és orvosolni tudja azt. A roma családok ezzel ellentétben sok esetben nem mutatnak nagy támogatást és együttmüködést, ami elengedhetetlen a sikeres nevelés és oktatás végrehajtásához, inkább úgy 
tartják, az iskola arra való, hogy az alapkészségeket, mint az írás, olvasás és számolás megtanítsák a gyerekeknek.

A szociális-emocionális területen mutatkozó eltérések részben okai, részben következményei is lehetnek a tanulási problémáknak. Pap (2010) szerint zavarok mutatkozhatnak:

- a késztetések területén (apátia, passzivitás, túlérzékenység, hiperaktivitás),

- az általános pszichés állapotban (levertség, féktelenség, szorongás),

- a motiváció alakulásában (motiválatlanság, megközelíthetetlenség),

- a munkavégzésben (gyors kifáradás, vontatott tempó, impulzivitás),

- az önirányításban (rövid zárlati cselekvések, labilitás),

- az önértékelésben (kisebbségi érzés, hiányos énkép, túlzott elbizakodottság, egocentrizmus)

- és a szociális beilleszkedésben.

A romák munkaerő-piaci elhelyezkedési lehetőségei nehezek, ezt tovább nehezíti a szociális kompetenciák hiánya. A romák munkaerő-piaci sikertelenségének egyik legfontosabb oka a modern kapitalista gazdaságban szükséges készségek nagymértékü hiánya. Ezen készségek kialakulásának pedig egyik legfontosabb színtere az iskola. Ezért logikus a következtetés, hogy a roma kisebbség hosszú távú sikerességének fontos tényezője az oktatás. A legújabb munkaerő-piaci kutatások kimutatják, hogy az úgynevezett „kognitív” készségek és kompetenciák (pl. számolási készségek, szövegértés) mellett a pozitív önértékelés, a sorsirányítás képességének érzése vagy a nehéz helyzetekkel való megküzdés készsége ugyanolyan fontosak a munkaerő-piaci sikerhez (Kézdi és Surányi, 2008).

Nagy József szerint a szociális kompetenciának vannak öröklött és tanult komponensei. A szociális kompetencia kialakulását befolyásoló tényezőknek a következőket tekinti: az egyén személyisége, a család és az iskolai környezet. Tehát, ha a szociális viselkedésnek vannak tanulható elemei, akkor tanítható is, ha megfelelö tanulási tapasztalatokat szerezhetnek a gyerekek. Mivel a szocializáció egyik helyszíne az iskola, az oktatásban részt vevőknek meghatározó szerepük van a hatékony szocializációs folyamatok irányításában. A szocializáció tanulható és tanítható folyamat, a szociális képességek és készségek fejlesztése minden tanuló érdeke, a társadalomnak pedig természetes elvárása (Radnóti, 2005). A szociálisan sikeres gyerekeknek több lehetséges technikájuk létezik a mindennapi interperszonális helyzetek kezelésére. Ezek magukban foglalják a várható problémák kialakulása iránti fogékonyságot, az alternatív cselekvési lehetőségek elgondolását, továbbá a cselekvések következményei, ill. a viselkedésben megmutatkozó ok-okozati hatás iránti érzékenységet (Nagy, 2003). A szociális kompetencia fejlődése lényegét tekintve a szociális komponenskészletek gyarapodása (vagyis szokások, minták, attitűdök, meggyőződések, készségek, ismeretek sokaságának elsajátítása), az egyéni szociális értékrend erősödése, a kreativitás növekedése révén valósul meg (Szegál, 2007).

Az inklúziós törekvések ellenére a hátrányos helyzetü tanulók átlagon aluli kognitív és szociális készségek és képességek birtokában csak pár éven keresztül maradnak a többségi általános iskolában, a pedagógusok ajánlására (amint a szülő engedélyezi és a szakszolgálat elfogadja a javaslatot) átkerülhetnek a szegregációs oktatásba, a speciális tagozatra, kisegítő iskolába. Feltételezésünk szerint, ha a hátrányos helyzetű tanulók szociális kompetenciáit sikerülne egy meghatározott szintig fejleszteni, nem kerülnének át speciális tagozatra, talán átlagon aluli eredménnyel, de befejezhetnék az általános iskolai oktatást normál tagozaton. Erre a problémára kerestünk egy hosszú távon is fenntartható megoldást.

\section{A hallgatói mentorprogram bemutatása}

A vajdasági Kanizsa Község túlnyomórészt magyarok lakta településének egyik jelentős problémája volt a Horgosi Október 10. Általános Iskola roma tanulóinak oktatása és nevelése. 
A gyakorló pedagógusok kétségbeesett beszámolói szerint a 2010-ben meghozott új oktatási törvény szerinti együttnevelés rengeteg problémával járt, a nem roma és a roma tanulók oktatásában egyaránt. Az iskola nem volt felkészülve a tömegesen beiskolázott roma gyerekek szocializációs nehézségeinek kezelésére, és ez egyre nagyobb problémát jelent a településen. A 2013/2014-es tanévben a Motiváció Hallgatói Mentorprogram az EDUCOOPprojekt (Educational Cooperation for Disadvantaged Children and Adults) részeként, az IPA Magyarország-Szerbia Határon Átnyúló Együttmüködési Program keretein belül valósult meg, a Szegedi Tudományegyetem Felnőttképzési Intézetének és az Újvidéki Egyetem Magyar Tanítási Nyelvü Tanítóképző Karának együttműködésében, a Motiváció Oktatási Egyesület szakembereinek közremüködésével. A 2013/2014-es tanévben mind Szegeden, mind Szabadkán 15 felsőoktatási hallgató mentorált 45-45 hátrányos helyzetủ általános iskolás diákot. A mentorprogram magyar oldalon három szegedi általános iskolában, szerb oldalon egy intézményben, a horgosi általános iskolában müködött.

A Hallgatói Mentorprogram célja, hogy intenzív kulturális, oktatási és kutatási együttmüködés alakuljon ki a partnerek között, valamint, hogy a hátrányos helyzetủ és roma származású gyerekek szociális és tanulmányi integrációjának támogatására megfelelő szakmai háttér alakuljon ki a tervezett tevékenységek által (Takács, 2014).

Az Újvidéki Egyetem szabadkai Magyar Tannyelvü Kara (MTTK) és a Felnőttképzési Intézet között fennálló, hosszú évek óta tartó gyümölcsöző együttmüködés eredményeképpen merült fel a mentorprogram kiterjesztésének lehetősége a Vajdaságban is. Ehhez nemcsak az MTTK oktatóinak és hallgatóinak bevonására volt szükség, hanem egy állandó gyakorlóhelyszín kiválasztására is, mégpedig úgy, hogy az egy olyan együttmüködő iskola legyen, amelyben a hátrányos helyzetü tanulók felzárkóztatására nagy az igény. Az MTTK hallgatói a térség különböző településeiről érkeznek, ezért az oktatók tájékozódhatnak a helyi viszonylatokban tapasztalható gondokról. Nagyon sok olyan körzet van, ahol nemcsak egyéni, hanem akár egész tagozatokra vagy iskolákra jellemző a hátrányos helyzetü gyerekek jelenléte. Feltérképezve a helyzetet a horgosi Október 10. Általános Iskolára esett a választás, amely földrajzilag Szeged és Szabadka között félúton helyezkedik el. Nagyszámú, szociális helyzetükből adódóan hátrányos helyzetü, illetve roma diákkal dolgoznak, és a mindennapjaik része a velük való külön foglalkozás. Már korábban is sokat tettek a gyerekek és az érintett családok érdekében, de a módszertanilag megalapozott mentorprogramban való részvétel lehetöségét különösen fontosnak érezték. Az iskola igazgatója és az érintett pedagógusok pontos és értékes adatokkal szolgáltak a projekt előkészítésekor, a megvalósítás ideje alatt pedig mindent elkövettek annak érdekében, hogy a diákokkal történő foglalkozások zökkenőmentesek legyenek. Az MTTK mentorhallgatóinak, akik a szegedi tapasztalatok alapján, szakmai felkészítés mellett végezték a felzárkóztató munkát, emberileg, módszertanilag is sokat segítettek. A program vajdasági, illetve horgosi alkalmazását kutatások kísérték, adaptálásának eredményeit felmérések igazolják, amelyekhez ugyancsak szükség volt az Október 10. Általános Iskola pedagógusainak segítéségére.

\section{A mentorpogram megvalósítása}

A mentorprogramnak három alappillére volt. Az első ezek közül maga a képzés és a képzési anyag kidolgozása. Öt tanítóképzős tantervbe integrált tantárgyat vehettek fel hallgatóink. Ezek voltak a Hátrányos helyzetü tanulók integrációja, oktatási problémáinak kezelése, Innovatív oktatási megoldások, Motiváció a hátrányos helyzetü tanulók körében, Felnőttképzés a hátrányos helyzetü csoportok körében, A nyelvi hátrányos helyzettől az analfabetizmusig.

A második volt maga a hallgatói mentorprogram, amely leegyszerüsítve abból állt, hogy egy mentorhallgató három mentortanulóval foglalkozik a tanév során. Ez a foglalkozás 
magában foglal korrekciós, prevenciós, tanulmányi felkészítést, fejlesztést, szabadidős programokat, és többek között még a szociális kompetenciák erösítését is. A 45 tanuló egyéni oktatási terv szerint tanult.

A harmadik alappillér pedig a kutatás volt. A program ideje alatt három kutatási területet öleltek fel a felmérések és azok kiértékelései: a közösen kidolgozott képzési anyagok hatékonyságának vizsgálata hallgatói kérdőívek és fókuszcsoportos beszélgetések segítségével; a Mentorprogram eredményének, a mentorok tapasztalatainak vizsgálata interjúk segítségével; a Mentorprogram fenntarthatósági és disszeminációs stratégiájának kidolgozása. Valamint elkészült egy tanulmánykötet is A szabadkai-horgosi mentorprogram tapasztalatai címmel. Ezen kötetben 126 horgosi hátrányos helyzetü és átlagos társadalmi státuszú kisiskolás kognitív, szociális, emocionális és fizikai teljesítményét vizsgáltuk, különböző mérőskálák segítségével.

2013. májustól augusztusig történt a tananyagok kidolgozása, szerbiai adaptálása. Július elején szerveztük meg a mentorok felvételi beszélgetését, ahol 30 hallgatót hallgattunk meg, és ebböl került ki 15 ösztöndíjas hallgató és 3 önkéntes hallgató. A mentorok kiválasztása egy kétlépcsős folyamat során történt. A jelentkezőknek először önéletrajzot és motivációs levelet kellett benyújtaniuk. A program követelményeinek megfelelően kialakított önéletrajzsablon a mentori munka szempontjából hasznos elméleti és gyakorlati tudás, valamint előzetes tapasztalatok felmérését célozta. A dokumentumok benyújtását követően egy felvételi beszélgetésre került sor, ahol a jelentkező rátermettségét, előzetes tapasztalatait, emellett a roma és a hátrányos helyzetü csoportok iránti attitüdjét tárták fel a programot koordinálók (Fejes, Kelemen és Szücs, 2014).

Szeptembertől indult a gyakorlati munka, a hallgatóknak egyszerre kellett megküzdeni az iskolai valóságsokkal és az önképzésükkel is, hiszen a kurzusok is akkor indultak el. Az iskolai munka kedden és pénteken valósult meg. Az öt kurzusból három az első szemeszterben került megszervezésre, a másodikban kettőt hallgathattak le hallgatóink. Szeptemberben csapatépítő tréninget szerveztünk a mentoroknak. A félév során hallgatóink részt vettek az iskolanapon, karácsonyi készülődésekben, szabadidős programokban, kirándulásokon. Többnyire csak kezdeti problémák voltak a pedagógiai munkával kapcsolatban. Sok kérdés és kétség fogalmazódott meg a mentorokban, amelyeket hamar sikerült megválaszolni, ilyen volt például, hogy milyen fajta pedagógiai munkát kell végezni, mennyire lehet befolyásolni a kisdiákok szociális kompetenciáit, mennyire lehet beleszólni az iskolai életbe. Nagy segítséget jelentett az általános iskolás gyakorló tanítók konstruktív munkája, valamint a közös fórumokon, megbeszéléseken megvitatott problémák, egymás tapasztalatainak meghallgatása, lehetőségek mérlegelése.

Két hallgatói csereprogramot szerveztünk, ahol találkozhattak a mentorok és ötleteket oszthattak meg egymással Szegeden és Szabadkán is. Júliusban pedig két gyereknapot is tartottunk, szintén mindkét városban, az összes mentorált tanulóval és mentorral együtt. Záró konferenciánkra június 27-én Szabadkán került sor. Fontos tapasztalatnak mondhatjuk, hogy egy gyakorlati oktatást kaptak a hallgatóink, amely egy lényeges szempont volt a program megvalósítása kapcsán.

\section{A mentortorok véleménye}

A következőkben Losonc Szintia, Januskó Izolda és Valkovics Melinda mentorok összefoglalóját mutatjuk be a mentorprogramban vállalt szerepükről: „2013 májusában hallottunk először a programról, akkor még nem tudtunk, mit jelent. Júniusban volt egy nyitókonferencia, ahova el lehetett látogatni, de semmilyen kötelezettséget nem jelentett. Ott betekintést nyertünk a mentorprogramba, hogyan dolgoznak, mik a céljaik, jó gyakorlatok bemutatása, és milyen nehézségekkel kell megküzdeni egy mentornak. Szeptemberben 
mentünk el először Horgosra, és az első hónap a kapcsolat kialakításáról szólt, vagyis az ismerkedésről. Lassan kialakult minden, tisztában lettünk azzal, hogy mit és hogyan kell megtanítani a gyerekeknek. Olyan tudást kaptunk a kurzusokon, amit fel tudtunk használni az iskolában. A tanulókat elsősorban matematikából és magyar nyelvből próbáljuk felzárkóztatni, de nagy szükségét láttuk a hátrányos helyzetükből adódó hiányzó szocializációs képességek pótlásának. Minden mentornak megvan a maga módszere a motiválásra. Ha nincs kedvük olvasni, játékkal tudjuk őket motiválni.

Mindenkinek vannak pozitív és negatív élményei a mentorprogrammal kapcsolatban, de az utóbbi leginkább csak a kezdeti nehézségekre kapcsolatos. Mindenki szép élményekkel fogja zárni ezt a programot, de én a legszívesebben arra gondolok vissza, hogy a gyerekek és a tanító is gyorsan befogadtak az osztályközösségbe. A céljaink is eltérőek, mert aki olyan osztályban van, ahol elsős gyerekekkel foglalkozik, neki az a fontos, hogy a többiekkel tudjon haladni, aki pedig negyedikessel, neki az a célja, hogy megtanítsa írni-olvasni.

Egy kis közösséget kovácsoltunk már össze, szabadidős tevékenységeket is szervezünk, nagyon sok kisgyerek nem is látott még mesét, és ezekre is szakítunk időt. Amellett, hogy a nyelvi és matematikai képességeket alapozzuk, szakítunk időt a képzőmüvészeti és zenei nevelésre is. Többnyire ezek a gyerekek kiszakadnak az osztályból, sokszor csúfolják öket, és kiközösíti őket az osztály. A mentorhallgató egy pótanyuka, barát szerepét vette fel, akihez jó ragaszkodni, és ha a gyermek bizalmába tud férkőzni a mentor, mindent el tud érni nála. A mentorok közötti együttmüködés is nagyon szépen kialakult, minden eszközt és játékot, amit elkészítettünk, továbbadjuk, hogy a többi mentor is felhasználja. Az én hallgatóim között van olyan kislány, aki az iskolában nem szólal meg, nem kéredzkedik ki az illemhelyre sem, a tanítónővel, osztálytársaival egyáltalán nem kommunikál. Nála elértem azt, hogy velem baráti szinten teljesen jól beszél, mindent elmond. Most már a barátaival is kezd beszélgetni, és remélem, júliusban már arról számolhatok be, hogy teljesen feloldódott.

Úgy érzem, hogy van értelme annak, amit csinálunk, és nagyon büszke vagyok rá, hogy részese lehettem a mentorprogramnak. Az eredményeinket nem tudjuk számbelileg kimutatni, de a tanítók visszajelzése az, amiböl eröt és motivációt gyüjthetünk. Nagyon fontosnak tartom elmondani azt, hogy az egyetemi tanárainkkal és a horgosi iskola dolgozóival is nagyon jó a kapcsolatunk, és ez az együttmüködés nagyban hozzájárul a sikerhez."

\section{A mentorált tanulók szociális kompetenciáinak fejlődése}

Mivel a Hallgatói Mentorprogram a mentorált tanulók fejlődését több oldalról kívánja támogatni, mint pl. a mentorált tanulók tanulmányainak felzárkóztatása, a szociális integráció segítése, a tanulók személyes és szociális kompetenciáinak fejlesztése (Kelemen, Szücs, Fejes, Németh és Csempesz, 2013), sok esetben rendkívül nehéz meghatározni azt a célt, amelynek elérése az adott mentorált tanuló kapcsán rövid távon kitüzhető. A hátrányok általában komplexen, és egymásra is hatva jelentkeznek, ami még inkább megnehezíti a célok kitüzését (Józsa és Fejes, 2010). A projektum szabadkai oldalánál érzékelhetően nagyobb hangsúlyt kapott az oktatást segítő, azt kiegészítő tevékenységek mellett a szociális beilleszkedés támogatása, integrált szabadidős programok szervezése. Félig strukturált interjú segítségével vizsgáltuk a horgosi mentorprogramban részt vevő gyakorló pedagógusok tapasztalatait a mentorált tanulók szociális kompetenciáinak tartós javulását tekintve. Több pedagógus arról számolt be, hogy a program lefolyása utáni évben volt leginkább érezhető és kimutatható a hatás, akkor, amikor egyedül maradt a mentorált gyerekekkel. A tanulók képesek voltak az önálló szociális integrációra, egyedül dolgoztak, elvégezték a kiosztott feladatokat, és az osztályközösség befogadóbb, elfogadóbb 
magatartást tanúsított irányukba. Az az első osztályos gyermek, aki a mentorprogram alatt egyéni fejlesztési tervvel tudott haladni, 3. osztályra már az átlag tanulók közé tartozik. Azzal a segítséggel, hogy különleges bánásmódban részesültek egy teljes tanéven keresztül a mentorok által, az alap kognitív kompetenciákban felzárkóztak, és a társas viselkedésekben is észrevétlenül beilleszkedtek az többi tanuló közé. Az interjúk során megkérdeztük, hogy a pedagógusok miben látják a megoldást: „Így, ahogy itt megtörtént, meg kellene ismételni a mentorprogramot, és nem azon kell gondolkodni, hogy legyen-e folytatás, hanem, hogy hogyan legyen!"

Egy másik pedagógus elmondása szerint: „...sajnos még mindig van olyan gyerek, aki nem beszél, zárkózott, idő kellene, és egy támogató barát (mentor), akit közel tudna engedni magához". Az érzelmi kompetencia fejlődésében - akárcsak a szociális kompetencia esetében - a biológiai alapprogramok és a környezeti tényezők egyaránt nagyon fontos szerepet játszanak (Saarni, 1999). A gyerekek érzelmeire és viselkedésére adott szülői és tanári válaszok hatásának azonosítása szintén számos pedagógiai probléma megoldását segíthetné. Külföldi kutatások egyértelmüen bizonyítják, hogy az iskolai évek alatt a pedagógusnak igen fontos szerepe van a szociális és az érzelmi kompetencia fejlödésében (Zsolnai és Kasik, 2007). Egy pedagógus véleménye alapján: „...a hátrányos helyzetü gyerekek leginkább magukat különítik el, még akkor is, ha az osztály befogadó lenne. Tud olvasni, szépen megtanult, de suttog. Nagyon gátlásos. Nagyon fontos a kapcsolati tőke, ők azok, akik ölelnek, szeretnek, puszilnak..."

\section{A jövőbeli tervek, lehetőségek}

A Hallgatói Mentorprogram elsődleges célja a hátrányos helyzetü tanulók tanulmányi felzárkózásának és szociális integrációjának segítése volt, de közvetett módon a pedagógusjelöltek szakmai felkészítésének támogatása és a társadalmi érzékenyítés elősegítése is a célkitüzések között szerepelt (Szücs és Fejes, 2010). A mentorprogram koordinátora is elmondta, hogy minden utat megpróbált megmozgatni, mert annyira jónak ítélte meg a programot, keresik a lehetőségeket. A mentorprogram megvalósítható lenne, akár másik falusi általános iskolában is, csak a mentorok útiköltsége, bérezése a pénzügyi probléma, amit le kellene győzni. A tanítóképző karon folyó pedagógus-továbbképzések alkalmával a gyakorló tanítók elmondása szerint nagyon nagy igény lenne a pedagógusi asszisztens bekapcsolására, még akkor is, ha egy gyakorlati tapasztalatokkal nem rendelkező hallgató személyében történne. Diákjaink szakmai gyakorlatot szereznek, a pedagógusok, pedig ezáltal nagy segítséget kapnának. Abból a szempontból nehezen követhető a szociális kompetencia változása, hogy ezek a gyerekek mára már a felső tagozatos tanárok irányítása alá kerültek, akik viszont nem látták őket az előzőekben, nem ismerik a bemenő szociális kompetenciájukat.

Fontos megállapítás a részünkröl, hogy amint sikerül a programot újra életre kelteni, mérni fogjuk a tanulók bemenő és kimenő alap- és szociális kompetenciáit, hogy pontos statisztikai adatokkal tudjuk alátámasztani a jó gyakorlatunk sikerességét.

\section{Irodalom}

Fejes J. B., Kelemen V. és Szűcs N. (2014). A Motiváció Hallgatói Mentorprogram Modellje - Útmutató felsőoktatási hallgatók részvételével szervezett hátránykompenzáló programok megvalósításához. Szeged. Letöltés: 2015.október 7.; Web: http://www.staff.uszeged.hu/ fejesj/pdf/FJB_KV_SZN_mentorprogram_ekonyv_hu.pdf 
Forray R. K. és Hegedüs T. A. (1998). Cigány gyermekek szocializációja. Család és iskola. Aula Kiadó Kft., Budapest.

Józsa K. és Fejes J. B. (2010). A szociális környezet szerepe a tanulási motiváció alakulásában: a család, az iskola és a kultúra hatása. In Zsolnai A. és Kasik L. (szerk.): A szociális kompetencia fejlesztésének elméleti és gyakorlati alapjai. Tankönyvkiadó, Budapest. 134-162.

Kalocsainé S. H. és Varga A. (2005). Az iskola mint társadalmi és oktatási idea. Educatio, 1. sz. 204-208.

Kelemen V., Szücs N., Fejes J. B., Németh K. és Csempesz P. (2013). A Hallgatói Mentorprogram. In Fejes J. B. és Szücs N. (szerk.): A szegedi és hódmezővásárhelyi deszegregációt támogató Hallgatói Mentorprogram. Öt év tapasztalatai. Belvedere Meridionale, Szeged. 107-127.

Kézdi G. és Surányi É. (2008). Egy sikeres iskolai integrációs program tapasztalatai. Kutatási összefoglaló. Educatio Társadalmi Szolgáltató Közhasznú Társaság, Budapest. Letöltés: 2015. október 6.; Web: http://old.wekerle.gov.hu/download.php?doc_id=2072.

Lepes, J., Csapó M., Bagány Á. és Grabovác B. (2014). A szabadkai-horgosi mentorprogram tapasztalatai. Grafoprodukt, Szabadka.

Nagy, J. (2003). Szociális kompetencia és proszocilaitás. In Zsolnai A. (Szerk.): Szociális kompetencia - társas viselkedés. Gondolat Kiadó. Budapest. 2003. 120-137.

Papp G. (2010). A tanulásban akadályozott tanulók és az olvasás. Könyv és Nevelés. XII. évfolyam, 2010/01 szám, Olvasáspedagógia rovat.

Radnóti, K. (2005). A szociális kompetencia fejlesztési lehetőségei a mai magyar iskolában a tanórákon. In Kerber Z. (Szerk.) Hidak a tantárgyak között. Országos Közoktatási Intézet, Budapest. 105-120.

Saarni, C. (1999): The Development of Emotional Competence. Guilford Press, New York.

Szegál, B. (2007). A sajátos nevelési igényü és hátrányos helyzetü tanulók integrált oktatásának és nevelésének megalapozása. In Girasek J. (szerk.): Inkluzív nevelés - A tanulók hatékony megismerése. SuliNova Közoktatás-fejlesztési és Pedagógustovábbképzési Kht., Budapest. 53-68.

Szücs N. és Fejes J. B. (2010): A deszegregációs intézkedéseket támogató Hallgatói Mentorprogram lehetőségei a pedagógusképzésben. In: Albert G. (szerk.): $A z$ óvodapedagógiától az andragógiáig. Kaposvári Egyetem Pedagógiai Kara, Kaposvár. 113125.

Takács M. (2014). Előszó. In A szabadkai-horgosi mentorprogram tapasztalatai. Grafoprodukt, Szabadka.

Törteli, Á. (2014). The Interpretation of Inclusive Education in Serbia. In Ambrusné Kéri K. (szerk.): Perspektívák a neveléstudományban. PTE BTK „Oktatás és Társadalom” Neveléstudományi Doktori Iskola, Pécs.

Zsolnai, A. és Kasik, L. (2007). Az érzelmek szerepe a szociális kompetencia müködésében, Új pedagógiai szemle 57. évf. 7-8. sz.. július/augusztus. Letöltve: 2015. október 06.; Web: http://epa.oszk.hu/00000/00035/00115/2007-07-ta-Tobbek-Erzelmek.html 


\section{KÖNYVAJÁNLÁS, RECENZIÓ}


KÜLÖNLEGES BÁNÁSMÓD, I. ÉVF. 2015/2. 


\section{KONCZ ISTVÁN NAGY KÉZIKÖNYVE TRÉNEREKNEK (Recenzió)}

\section{A recenzió szerzője:}

Mező Ferenc

Debreceni Egyetem

Szerző e-mail címe:

ferenc.mezo1@gmail.com

\section{Lektorok:}

Mező Katalin

Debreceni Egyetem

Schéder Veronika

Debreceni Egyetem

Szilágyi Barnabás

Debrecni Egyetem

Varga Imre

Szegedi Tudományegyetem

Mező Ferenc (2015): Koncz István nagy kézikönyve trénereknek (Recenzió). Különleges Bánásmód, I. évf. 2015/2. szám, 97-98. DOI 10.18458/KB.2015.2.97

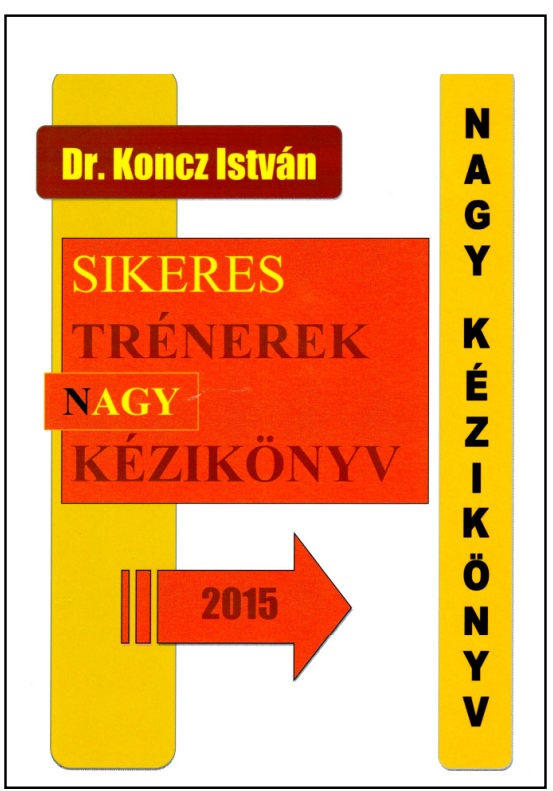

\section{A recenzió alapjául szolgáló mü bibliográfiája:}

Koncz István (2015): Sikeres trénerek nagy kézikönyve. FITT IMAGE Kft., Budapest. 412 oldal, ISBN: 978-96312-3898-3

Kulcsszavak: tréning, személyiség, kommunikáció, csoport

Diszciplinák: pszichológia, pedagógia, gyógypedagógia

\section{Bibliography of the subject of this recension:}

Koncz, István (2015): Sikeres trénerek nagy kézikönyve. FITT IMAGE Kft., Budapest. pp. 412, ISBN: 978-963$12-3898-3$

Keywords: training, personality, communication, group Disciplines: psychology, pedagogy, special education

Sikeres tréningek tartására irányuló jó kívánsággal ajánlom minden érdeklődő számára a Sikeres trénerek nagy kézikönyvét!

A Szerző, Koncz István (CSc, PhD) több, mint 30 éve oktat és kutat hazai felsőoktatási intézményekben. Korábban a kamaszok és a tanárok, manapság elsősorban az üzletemberek személyisége áll érdeklődése középpontjában. 1990-94 között a Magyar Tudományos Akadémia Pszichológiai Intézetének ügyvezető igazgatója volt, jelenleg a Professzorok az Európai Magyarországért Egyesület ügyvezető elnöke. Tréningek és trénerképzések százait valósította meg, illetve felügyelte szupervizorként az elmúlt évtizedekben. Sokoldalú munkásságának ez utóbbi aspektusainak tapasztalatait foglalja össze jelen recenzióban tárgyalt müve. 
A Sikeres trénerek nagy kézikönyve egy napjainkban is formálódó és sok szakmai vitát kiváltó módszerre fókuszál: a tréningre. A Szerző kifejti, hogy a tréningeken nem feltétlenül tudásátadás történik, mint inkább egyfajta segítségnyújtás ahhoz, hogy a résztvevők önmagukkal kapcsolatban (egyfajta veszély nélküli „,próbapályán”) olyan új, sehol máshol nem megtapasztalható felismerésekhez jussanak, amelyek önfejlesztési folyamatokat indíthatnak be. Ezen túl esetenként már meglévő vagy újonnan alakult viselkedésminták készségszintre történő fejlesztése történhet meg a tréningeken. Lényeges, hogy még ugyanazon forgatókönyv, tréning tematika alapján sincs két egyfajta tréning, mivel a tréninget alkotó személyek és a belőlük képződött csoport más és más. A sikeres tréningvezetéshez éppen ezért lényeges ismeretekkel és technikákkal rendelkezni a csoportok kialakítása, irányítása terén is. Ideális esetben a csoportot alkotók olyan önismereti munícióval távoznak a tréningről, amely részben megerősíti őket, részben pedig továbbfejlődésre ösztönzi őket, $s$ ezáltal intra- és interperszonális hatékonyságuk is javulhat. Ez utóbbi területhez, a személyközi hatékonysághoz, azonban olyan kommunikációs és konfliktuskezelési tudásra, jártasságra is szükség van, ami a szocializáció során nem feltétlenül alakul ki mindenkiben. Egy sikeres tréner által tartott sikeres tréningnek e téren is sikerekhez illik juttatnia a résztvevőket.

A Sikeres trénerek nagy kézikönyve célközönségét a humán területeken (például: pszichológia, pedagógia, szociális munkás, kommunikációs és humán erőforrás, jogi, egészségügyi pályán) tanulók, tréningeket tartók körében határozhatjuk meg. Koncz István külön felhívja a figyelmet arra, hogy a tehetségfejlesztő tanárok, edzők, szakértők alkotta potenciális célközönségre. A könyv vitathatatlan tartalmi súlya mellett - ugyancsak vitathatatlan - fizikai súlya és gerincvastagsága alapján erős bicepszet és kidolgozott alkart birtokló célközönséget is specifikálhatunk. Ráadásul a több mint 400 sürün írt oldal jelzi a Szerző közlési szándékát, azt hogy Olvasóinak valóban át kívánja adni több évtizedes szakmai tapasztalatát.

A mü öt nagyobb fejezetböl áll:

Az első fejezet olyan témaköröket jár körbe, mint: tréningmódszer, tréningtervezés, tréningvezetés, a tréner személyisége, értékelés és dokumentálás.

A második fejezet a csoport és a csoportvezetés elméleti és gyakorlati tudnivalóira fókuszál olyan témák mentén, mint: csoportdinamika, a csoport pszichológiai jellemzői, teljesítményt befolyásoló tényezők, elhárító mechanizmusok, ellenállás az önismereti csoportokban, indulatáttétel, csoportszabályok és -alakítás, a csoportban folyó fejlesztés lehetőségei.

A harmadik fejezet középpontjában az önismeret fogalma, vizsgálati és fejlesztési lehetősége áll. A Szerző rámutat az önismeret fejlesztésének szükségességére, belső és külső személyiségmarketing lehetőségeire. A fejezet pedig önismereti játékok, gyakorlatok és technikák bemutatásával zárja.

A kommunikáció elméleti és gyakorlati hátterére, a sikeres kommunikációra, a kommunikáció zavaraira és a kommunikációs készségek fejlesztésének lehetőségeire koncentrál a könyv negyedik fejezete.

Végül a könyv utolsó, ötödik fejezete a konfliktuskezelésre helyezi a hangsúlyt, miközben összefoglalja a konfliktusokkal járó stressz-kezelés lehetőségeit is.

A könyvben foglaltak trénerképzésen történő feldolgozását - előadásvázlatokat, teszt- és feladatmegoldásokat, bibliográfiai segédletet tartalmazó - CD melléklet segíti.

A könyv unikális jellegét a tréningvezetéssel kapcsolatos elméleti és gyakorlati ismeretek gazdagsága és ötvözése adja. A könyvben szereplő gyakorlatok kiválóan segítik a kezdő és a gyakorlott trénereket is abban, hogy valóban sikeresek lehessenek.

Jó olvasást, eredményes tanulást és sikeres tréningtartást kívánok minden kedves jövőbeli Olvasónak! 


\section{KONFERENCIA}


KÜLÖNLEGES BÁNÁSMÓD, I. ÉVF. 2015/2. 


\section{MEGHÍVÓ \\ A KORAGYERMEKKORI NEVELÉS CÍMÜ NEMZETKÖZI TUDOMÁNYOS KONFERENCIÁRA}

A Debreceni Egyetem Gyermeknevelési és Felnőttképzési Kara és a Gyermeknevelési tanszék tisztelettel meghívja Önt A Koragyermekkori Nevelés címü nemzetközi tudományos konferenciájára.

A konferencia ideje: 2016. május 25-26.

A konferencia helye: Debreceni Egyetem Gyermeknevelési és Felnőttképzési Kar (Hajdúböszörmény, Désány István u. 1-9.)

A konferencia hivatalos nyelve a magyar és az angol. Az előadásokat nemzetközi szerkesztőbizottság által szerkesztett, lektorált kötetben jelentetjük meg.

A konferencia fővédnöke, elnöke: Dr. Pálfi Sándor, tanszékvezető főiskolai tanár, dékánhelyettes DE GYFK és Dr. Verity Campbell-Barr Európai Unió Marie Curie Ösztöndíjas kutató DE GYFK

A konferencia titkára: Vargáné Dr. Nagy Anikó, adjunktus

Programbizottság:

Dr. Molnár Balázs, e-mail: molnarb@ ped.unideb.hu

Dr. Pálfi Sándor, e-mail: palfis@ @ed.unideb.hu

Vargáné Dr. Nagy Anikó, e-mail: vnaniko@ped.unideb.hu

Dr. Verity Campbell-Barr, e-mail: verity.campbell-barr@ ped.unideb.hu

Adminisztrátor: Bertalan Sándorné, e-mail: titkarsag@ped.unideb.hu

\section{Kapcsolattartók:}

Vargáné Dr. Nagy Anikó, e-mail: vnaniko@ped.unideb.hu

Bertalan Sándorné, e-mail: titkarsag@ped.unideb.hu

A Konferencia díszvendége Professzor Christine Pascal az Európai Koragyermekkori Nevelési és Kutatói Társaság (EECERA) elnöke, a Koragyermekkori Kutatóközpont megalapítója és igazgatója, Egyesült Királyság, és Professzor Tony Bertram az Európai Koragyermekkori Nevelési és Kutatói Társaság Folyóirat (EECERJ) szerkesztője, az EECERA alapító elnöke és védnöke, a Koragyermekkori Kutatóközpont megalapítója és igazgatója, Egyesült Királyság.

\section{A szakmai megújítás útjai, lehetőségei}

Az európai társadalmak és Magyarország is keresi a kisgyermekek fejlődési ismereteire, a korábbi intézményi, családi nevelés gyakorlatára épülő megoldásokat, melyek a jövő generációi számára az emberibb életkezdést, személyiség alapozást, az öröklés miatt rejtett diszpozíciók kibontakozását a gyerekekhez jobban igazított módon valósítja meg.

Konferenciánk közös szakmai teret kíván adni azoknak, akik megfogalmazzák és közreadják a fejlődő gyermekre alapozott pedagógiai tapasztalataikat, elképzeléseiket, kutatási eredményeiket annak érdekében, hogy a gyermeki aktivitás és a felnőtt felelősség egyensúlyát a XXI. század jelen világában is érvényesíteni tudjuk. 
A magyar felsőoktatás a pedagógusképzés kimeneti követelményeinek új adaptációja előtt áll, ezért szükségesnek tartjuk, hogy szélesebb szakmai körben is megfogalmazódjanak az elképzelések és azok értelmezési keretei. Teret biztosítunk minden kutató, oktató, nevelö számára, aki az elméletet és a pedagógiai gyakorlatot kívánja gazdagítani új gondolataival, tapasztalataival.

A plenáris elöadásokat szekciók és workshopok követik.

- A gyermekközpontú gyakorlat jelene és jövője

- Módszerek és szemléletek

- A szakemberek tudása, képességei és attitüdjei

- A gyermek és a helyi közösség

- A minőségi koragyermekkori nevelés gyakorlata

A részvételről a köznevelésben dolgozó kollégáknak a konferencia zárása után igazolást adunk ki, melyet a munkáltató beszámíthat a hétévenkénti továbbképzés kötelező 120 órájába.

A konferencia kísérörendezvényei:

- Szakkönyv-vásár

- Hajdúböszörmény Játéka - Grozdics Judit játékgyüjteményének kiállítása

- Óvodapedagógus hallgatók játékkiállítása

- Hallgatói bábszínház

- Óvodai projektek kiállítása

- A Kar zenei együtteseinek müsora

\section{A konferencián való részvétel}

Elöadóknak:

$8.000 \mathrm{Ft} / 25 \mathrm{Euro} / 20$ angol font (egy éjszaka szállás a Kar Kollégiumában egy ebéd, gálaest vacsorával, kávé, üdítő és publikáció)

Felsőoktatási hallgatóknak és érdeklödő résztvevőknek:

1.000 Ft (kávé, üdítő)

\section{Jelentkezési határidő:}

- Elöadással vagy poszter bemutatásával: 2016. március 20. Absztrakt elfogadásáról visszajelzés: 2016. április 20.

- Érdeklödö résztvevöként: 2016. március 30.

A részvétel regisztrációhoz kötött, mely a részvételi díj átutalásával együtt érvényes!

\section{Előadások és absztraktok elkészítésének paraméterei}

Az előadások időtartama 20 perc, amelyet 5 perc vita követ. A Konferenciára önálló kutatásra épülő, tudományos igényü előadásokat várunk, melyek a kisgyermekkori játék témához kapcsolódnak. Az előadáshoz szükséges technikai eszközöket (tábla, számítógép, projektor) biztosítjuk. Az absztrakt formai követelményei:

- 250-300 szó terjedelemben. Margóméretek (B/5-ös formátumhoz): felső: 4,8cm, alsó: $5,4 \mathrm{~cm}$, bal: $4,2 \mathrm{~cm}$, jobb: $3,8 \mathrm{~cm}$.

- A föszöveg Times New Roman betütípussal,10,5 pt-os betümérettel és 12,6 pt-os sortávolsággal.

- A lábjegyzetek (Times New Roman) betümérete 10, sortávolsága 10 pt.

A Konferencia végleges programjának kiírása április elején várható. 
Utazás és szállás egyéni szervezésben és foglalással (kedvezményes szállás kérhető a Kar kollégiumában).

\title{
Jelentkezés
}

A konferenciára jelentkezni a www.degyfk.hu honlapon keresztül lehet.

\section{Tájékoztatásul közöljük a konferencia legfontosabb határidőit:}

- Jelentkezés és absztrakt leadásának határideje: 2016. március 20.

- Értesítés a téma elfogadásáról, illetve elutasításáról: 2016. április 20.

- Jelentkezés érdeklődő résztvevőnek: 2016. március 30.

- A végleges előadás publikációra megjelentetett szerkesztésre és nyomtatásra történő leadásának határideje: 2016. június 30.

Várjuk jelentkezését, és kérjük, hívja fel kollégái és tanítványai figyelmét is a konferenciára!

\section{Üdvözlettel:}

\author{
a konferencia szervezői
}

